OECD Economics Department Working Papers No. 854

What Drives Inflation in the Major OECD Economies?

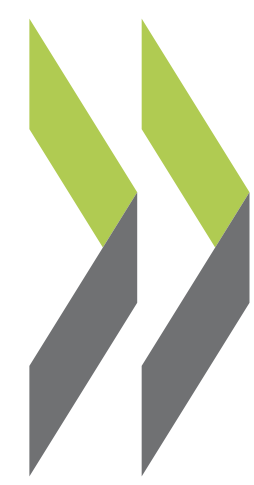

Diego Moccero, Shingo Watanabe, Boris Cournède 


\section{Unclassified}

ECO/WKP(2011)23

Organisation de Coopération et de Développement Économiques

Organisation for Economic Co-operation and Development

08-Apr-2011

ECONOMICS DEPARTMENT

English - Or. English

\section{WHAT DRIVES INFLATION IN THE MAJOR OECD ECONOMIES?}

ECONOMICS DEPARTMENT WORKING PAPERS NO. 854

By Diego Moccero, Shingo Watanabe and Boris Cournède

All economics Deparment Working Papers are available through OECD's internet website at http:/www.oecd.org/eco/Workingpapers 


\section{ABSTRACT/RESUME \\ What drives inflation in the major OECD economies?}

This paper presents an empirical analysis of the determinants of inflation in the United States, Japan, the euro area and the United Kingdom, focusing on the role of resource utilisation, inflation expectations, inflation persistence and imported inflation. It also includes a cross-sectional analysis that focuses on inflation dynamics over episodes of persistent large slack and low inflation. The main findings of this analysis are as follows: $i$ ) During the crisis, the stability of inflation expectations has held up actual inflation, so far preventing the huge slack in resource utilisation from leading to a disinflationary spiral; ii) Disinflationary pressures also seem to have been moderated by the flattening of the Phillips curve in an environment of persistent large economic slack and low inflation; iii) The link between long-term inflation expectations and past inflation outcomes has become weaker over time and appears to have almost disappeared recently; iv) The estimated Phillips curves coupled with the November 2010 projection of explanatory variables presented in the OECD Economic Outlook No. 88 and excluding the recent period of strong commodity prices point to inflation remaining low but positive, except in Japan where deflation is expected to continue past end-2012; v) The inflation outlook and associated risks argue for withdrawing monetary policy accommodation gradually in the short term, while being vigilant about the build up of broad-based inflationary pressures over the medium term.

JEL Classification: C53; E31; E52.

Keywords: United States; Japan; Euro area; United Kingdom; Phillips curves; core and headline inflation; disinflation; inflation forecast; inflation expectations; resource slack.

$* * * * * * * * * * * * * * * * *$

\section{Quels sont les facteurs d'inflation dans les économies de l'OCDE}

Cet article présente une analyse empirique des déterminants de l'inflation aux États-Unis, au Japon, dans la zone euro et au Royaume-Uni, mettant l'accent sur le rôle de l'utilisation des ressources, les anticipations d'inflation, la persistance de l'inflation et l'inflation importée. Il propose également une analyse de la dynamique de l'inflation au cours des épisodes durables de nette sous-utilisation des capacités et de faible inflation. Les principales conclusions de cette analyse sont les suivantes: $i$ ) Pendant la crise, la stabilité des anticipations d'inflation a empêché que le sous-emploi des ressources ne conduise à une spirale déflationniste, ii) Il semble également que les pressions désinflationnistes aient été modérées par l'aplatissement de la courbe de Phillips dans un contexte de faiblesse économique persistante et de basse inflation; iii) L'influence des derniers chiffres d'inflation sur les attentes d'inflation à long terme s'est affaiblie au fil du temps et semble avoir presque disparu récemment; $i v$ ) Des prévisions fondées sur les courbes de Phillips estimées et les projections des Perspectives Économiques de l'OCDE $\mathrm{n}^{\circ} 88$ de novembre 2010 excluant la période récente de hausse des prix des produits de base suggèrent une inflation restant faible, mais positive d'ici à fin 2012, sauf au Japon où la déflation devrait se poursuivre au moins jusqu'au-delà de cette période; $v$ ) La configuration des risques à court terme et à moyen terme plaide pour un retrait progressif de l'expansion monétaire en demeurant vigilant quant au risque d'apparition de pressions inflationnistes à moyen terme. .

Classification JEL: C53; E31; E52.

Mots-clés : États-Unis ; Japon ; Zone Euro ; Royaume-Uni ; courbes de Phillips ; fondement et base de l'inflation; désinflation; prévision d'inflation; les anticipations d'inflation; fluctuation des ressources.

Copyright $\odot$ O OECD, 2011.

Application for permission to reproduce or translate all, or part of this material should be made to: Head of Publications Service, OECD, 2 rue André-Pascal, 75775 Paris Cedex 16, France. 


\section{TABLE OF CONTENTS}

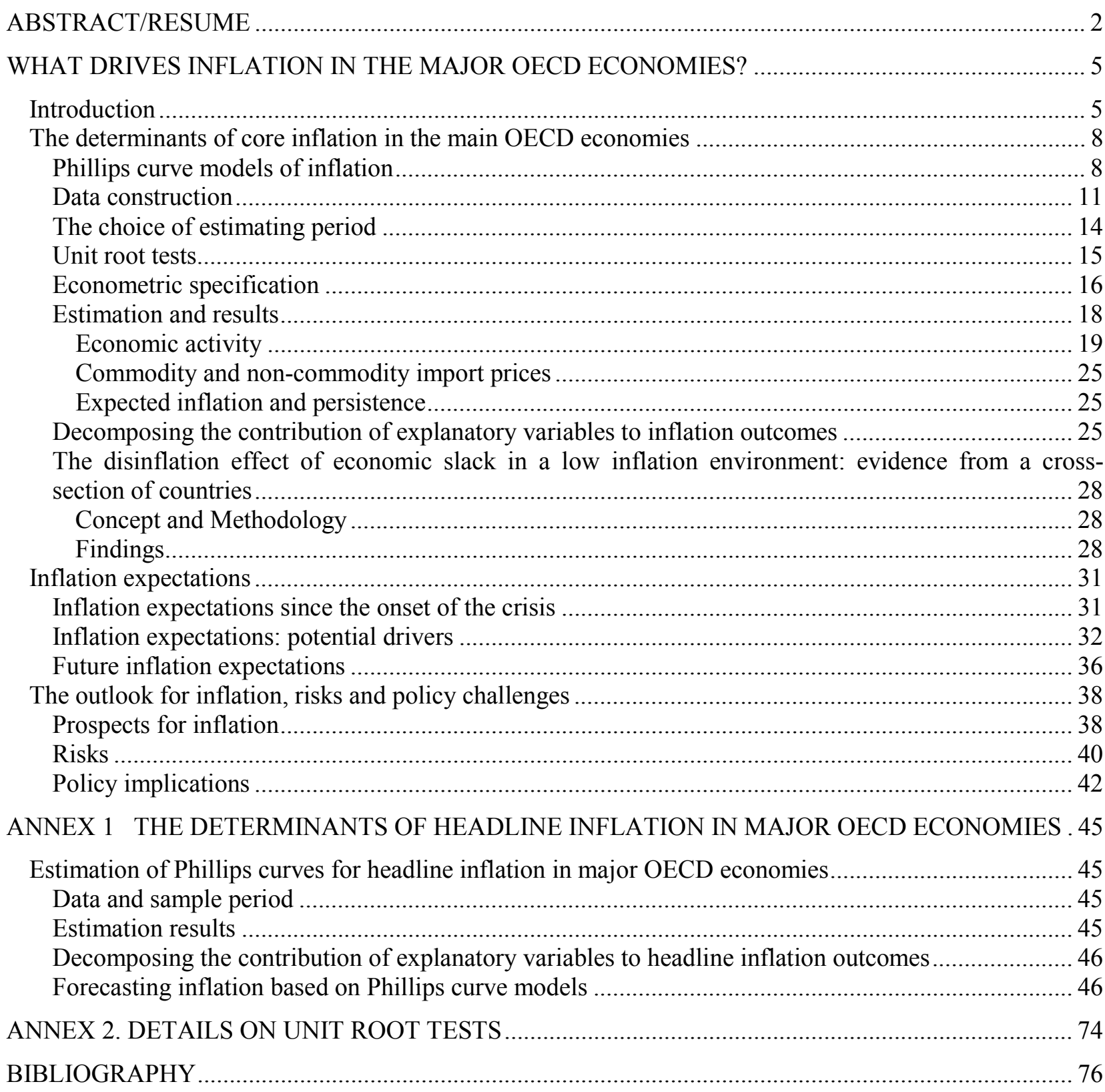

\section{Tables}

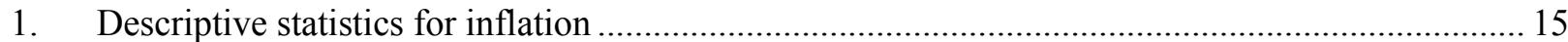

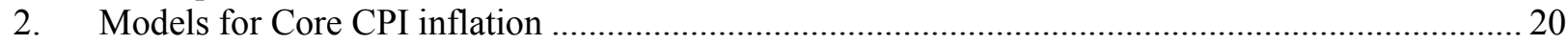

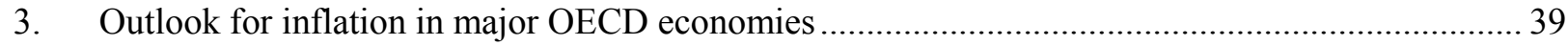

A1.1. Further description of data used in the empirical analysis ........................................................... 48

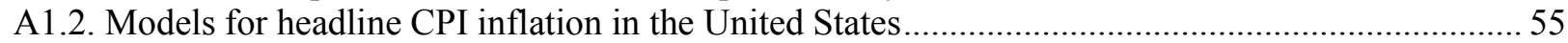

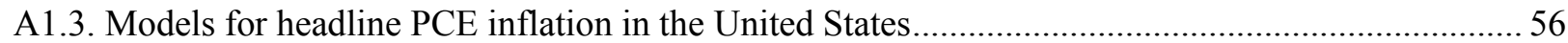

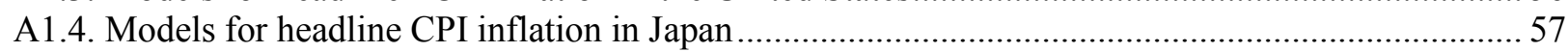




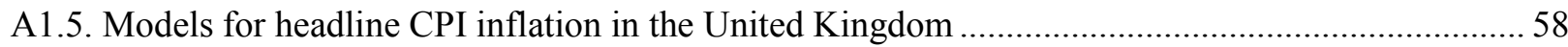

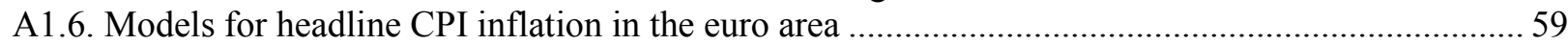

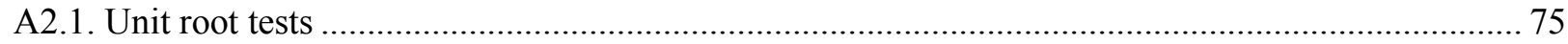

\section{Figures}

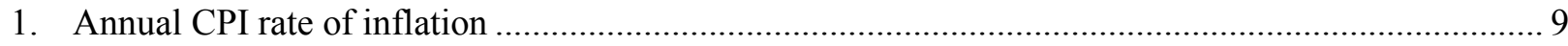

2. Evolution of underlying inflation measures in the United States ................................................ 10

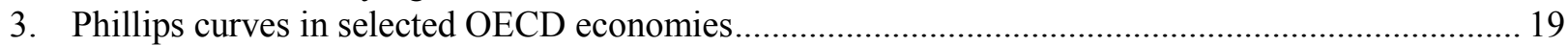

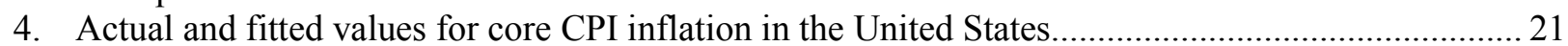

5. Actual and fitted values for core PCE inflation in the United States ............................................ 22

6. Actual and fitted values for core CPI inflation in Japan............................................................... 22

7. Actual and fitted values for core CPI inflation for the United Kingdom ...................................... 23

8. Actual and fitted values for core CPI inflation for the euro area................................................ 24

9. Response of core CPI inflation to economic activity and expected inflation shocks ....................... 24

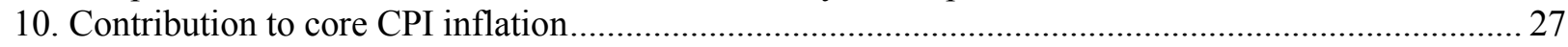

11. Evolution of core CPI Inflation during episodes of persistent large output gaps ............................. 29

12. Extent of disinflation vs. initial inflation level in episodes of persistent large output gaps ................. 30

13. Extent of disinflation vs. average size of the GDP Gap: the role of the initial inflation rate ............. 31

14. Long-term inflation expectations in the United States, the euro area and Japan............................... 33

15. Risk surrounding long-term inflation expectations in the United States and the euro area................ 34

16. Short term inflation expectations in the United States and in the euro area ...................................... 35

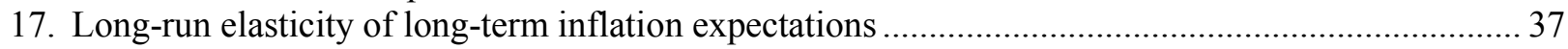

18. Projections for core CPI inflation based on the Phillips curve models ............................................. 40

19. Core inflation in the euro area and the United States under different scenarios for inflation

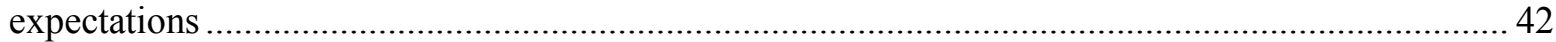

20. Core inflation in the United States under a narrower output gap ................................................... 44

A1.1. Actual and fitted values for headline CPI inflation in the United States....................................... 60

A1.2. Actual and fitted values for headline PCE inflation in the United States..................................... 61

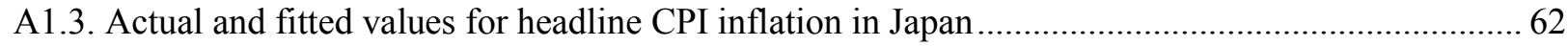

A1.4. Actual and fitted values for headline CPI inflation for the United Kingdom................................. 63

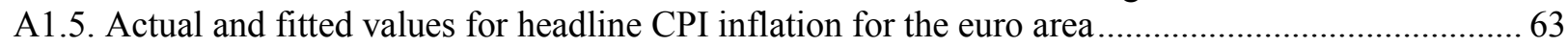

A1.6. Contribution to headline CPI inflation outcomes in the United States.......................................... 64

A1.7. Contribution to headline PCE inflation outcomes in the United States........................................ 65

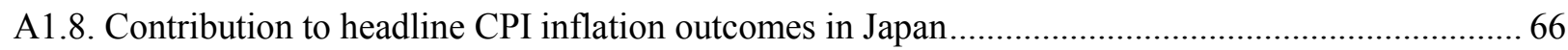

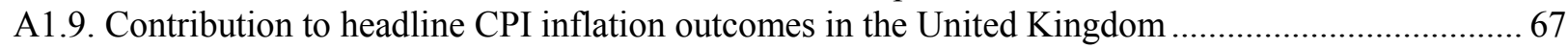

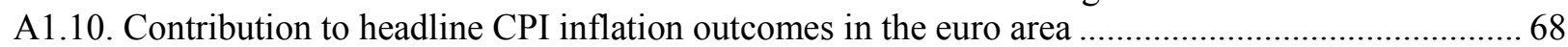

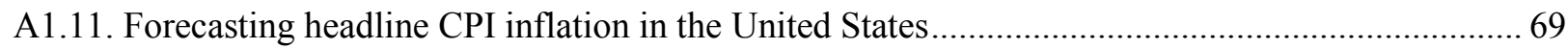

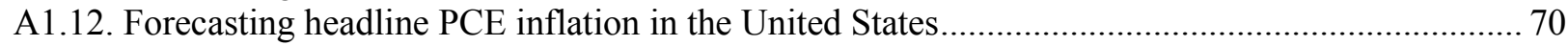

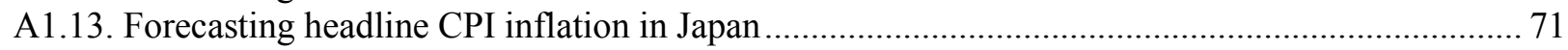

A1.14. Forecasting headline CPI inflation in the United Kingdom ..................................................... 72

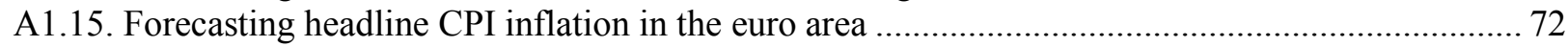

\section{Boxes}

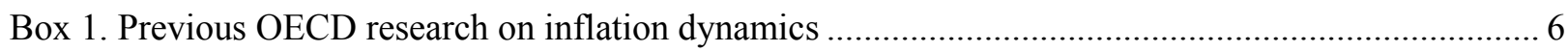

Box 2. Cross-country differences in the treatment of housing costs in consumer price indices ............... 26 
ECO/WKP(2011)23

\title{
WHAT DRIVES INFLATION IN THE MAJOR OECD ECONOMIES?
}

\author{
By Diego Moccero, Shingo Watanabe and Boris Cournède ${ }^{1}$
}

\section{Introduction}

1. Inflation has fallen to low levels in many OECD countries during the crisis, but has been rebounding recently on the back of the substantial appreciation in commodity prices and indirect tax increases (Figures 1 and 2). Given the large slack in labour and product markets in most member countries, underlying inflation is likely to remain below implicit and explicit targets of monetary authorities over the next two years in many economies. Against this background, at the end of last year a few central banks announced further quantitative easing to stimulate aggregate demand and have committed to fully implement such programmes. In contrast, in economies where inflation has raised the most recently, support is building up for an early withdrawal of monetary policy accommodation. The extent to which a few central banks have engaged in quantitative easing has also raised concerns about inflation in the longer term and has raised questions about the anchoring of expectations and credibility of price stability objectives of monetary authorities.

2. This paper explores the determinants of inflation dynamics in general and in a low inflation and a high slack environment in particular. It is based on an empirical analysis of the determinants of inflation using data until mid 2010 in the United States, Japan, the euro area and the United Kingdom The focus is on the role of resource utilisation, inflation expectations, inflation persistence and imported inflation in shaping inflation in the four economies under consideration. It also includes a cross-sectional analysis that focuses on inflation dynamics over episodes of persistent large slack and low inflation.

3. The analysis is concentrated on explaining core rather than headline inflation because underlying price developments, abstracting from temporary fluctuations, are of particular importance for monetary authorities pursuing medium-term inflation targets. However, recognising that the relationship between core, headline and underlying inflation can sometimes be complicated and that, ultimately, monetary policy is responsible for overall price stability, a detailed analysis of the determinants of headline inflation is presented in Annex 1.

4. The questions that the paper seeks to answer include the following: What have been the influences of the key potential determinants on core inflation in the major OECD economies in the recent past? How has inflation behaved during periods of sustained economic slack? What is the outlook for inflation? Are inflation expectations well anchored or are they influenced by past outcomes and events so that anticipated inflation could ultimately drift downwards or upwards? The focus on inflation expectations is one point of difference with previous OECD work on the subject (Box 1).

1. The authors are members of the Macroeconomic Policy Division of the OECD Economics Department. The authors are indebted to Jørgen Elmeskov, Jean-Luc Schneider, David Turner, Alan Detmeister and Lukasz Rawdanowicz for their useful comments. They nevertheless remain solely responsible for any remaining errors and omissions. The authors are also grateful to Debra Bloch and Catherine Lemoine for excellent statistical assistance and to Lillie Kee, Caroline Abettan and Isabelle Fakih for excellent technical preparation. The opinions expressed in this paper are those of the authors and are not necessarily shared by the OECD or its member countries. Corresponding author: diego.moccero@oecd.org. 


\section{Box 1. Previous OECD research on inflation dynamics}

Previous OECD research on inflation dynamics includes the following:

- The OECD Economic Outlook No. 85 (2009) argued that the risk of deflation or a deflationary spiral might be low in the current situation because of high central bank credibility and nominal wage and price rigidities. It also cited evidence of cases where long recessions resulted in no disinflation (Canada in the 1990s), no deflation (Finland in the early 1990s), or no deflation spiral (Japan since the 1990s).

- Pain et al. (2006) studied the relationship between, on the one hand, observed changes in the inflation process in the OECD economies and, on the other hand, the integration of non-OECD economies into the global economy. They found that domestic inflation in OECD economies was increasingly affected by import prices and became less sensitive to domestic output gaps while the effects of GDP growth in non-OECD economies on commodity prices increased.

- Cournède et al. (2005) found that inflation was less responsive to economic slack in the euro area than in other OECD countries and that more rigid labour and product markets in the euro area explained much of the difference.

- $\quad$ Catte and Sløk (2005) studied the properties of a number of core inflation measures. They found that core inflation rates were superior to headline inflation rates in tracking trend inflation and in predicting future headline inflation, and that the relative performance of different measures in predicting future inflation varied across economies and sample periods.

- Mourougane and Ibaragi (2004) focused on Japan's low inflation environment and found that the slope of the Phillips curve became flatter when inflation was below $1 / 2$ per cent and that there was a break in the relationship between demand pressure and inflation in the beginning of the 1990s.

- Vogel et al. (2009) studied the source of differences in monetary policy responses to commodity price increases in the first half of 2008 among G7 countries. Looking at the role of exposure to global price shocks, their propagation, and the policy objective, they found that the former two factors were particularly important.

The OECD also regularly publishes estimates of the NAIRU as important inputs for macroeconomic and structural policy analysis. Building on Elmeskov (1993) and Richardson et al. (2000), the methodology is regularly reviewed (Guichard et al., 2010).

Source: OECD.

5. The main findings of this analysis are as follows:

- The output gap and unemployment-related measures of the intensity of resource use have been important drivers of inflation in the four economies under consideration in past decades. In general, the impact of slack is relatively strong in the United Kingdom and Japan and weaker in the United States. In a few cases, evidence suggests that it is not only the level but also changes in intensity use that influences inflation developments (speed-limit effects).

- However, the analysis of episodes of persistent large output gaps suggests that the disinflationary effects tend to become weaker as inflation falls closer to zero, implying a higher sacrifice ratio. The implication for monetary policy is that a very strong stimulus may be required to push up inflation in such circumstances. 
- Inflation has displayed some degree of persistence in the past. Persistence has been relatively low in the United States and relatively high in the euro area.

- According to the empirical analysis, short-term inflation expectations play a key role in the inflation process in the United States and the euro area but not in Japan or the United Kingdom. Hence, as long as inflation expectations remain well anchored, slack and import prices will have only transitory effects on inflation. The link between long-term inflation expectations and past inflation outcomes has become weaker over time and appears to have almost disappeared recently, with long-term inflation expectations being close to implicit or explicit inflation targets of central banks.

- Changes in both commodity and non-commodity import prices have affected inflation developments in all the economies under review, with the effects becoming stronger over time with increases in import intensity. This in turn implies that currency movements and world commodity prices influence domestic inflation, though their effects can be complex due to incomplete and changing pass-troughs.

6. The implications of the analysis for inflation developments during the crisis and in the near future, and the associated policy implications, are:

- During the crisis, the stability of inflation expectations held up actual inflation, and prevented the huge slack in resource utilisation from leading to a disinflationary spiral. Disinflationary pressures also seem to have been moderated by the flattening of the Phillips curve in an environment of persistent large economic slack and low inflation.

- The estimated Phillips curves coupled with the November 2010 projection of explanatory variables presented in the $O E C D$ Economic Outlook No. 88 point to core inflation remaining low positive, except in Japan where deflation is expected to continue. Outside Japan, the estimated risk of deflation is relatively low, as long as inflation expectations remain constant or increase from their current levels. It is important to note that these projections may underestimate core inflation outcomes, as far as they do not account for the impact of the substantial commodity price increases and hikes in indirect taxes during the second half of 2010 and the beginning of 2011.

- This configuration of prospects and risks until the end of 2012 argues for withdrawing monetary accommodation gradually over this horizon, while being vigilant about the build up of broadbased inflationary pressures over the medium term. If necessary, monetary authorities should advance and accelerate the pace of monetary policy normalisation.

- In the long term, central banks should avoid that their unconventional measures put their credibility at risk in a context where the massive expansion in central bank liquidity can be perceived as adding inflation risks above and beyond those implied by strong commodity prices. Moreover, while keeping inflation expectations high can be useful in the short-to-medium term to avoid deflation concerns, authorities should also assess the risk of a de-anchoring of inflation expectations that can be particularly difficult to undo. All in all, it is particularly important that central banks communicate clearly their determination to tighten policy as the need arises.

7. The paper is structured as follows. Section 2 presents the empirical analysis. Section 3 briefly describes recent trends in long-term inflation expectations and presents estimates of their determinants in the euro area and the United States. The outlook for inflation is discussed in Section 4, together with risks surrounding the projections and the policy implications. 


\section{The determinants of core inflation in the main OECD economies}

8. This section explores the determinants of core inflation. It discusses the impact of resource utilisation, inflation expectations and persistence, and import prices on inflation on the basis of an empirical analysis. It also provides an assessment of the respective role of these factors in explaining past inflation outcomes and investigates if inflation dynamics in economies characterised by large margins of slack and low inflation, may be different from normal times.

\section{Phillips curve models of inflation}

9. The main drivers of core inflation can be analysed on the basis of Gordon's (1997) "triangle" Phillips curve model, where inflation is explained by three main factors: demand (output gap and unemployment-related measures of economic slack), external shocks, and past inflation. This model is extended here to include expected inflation, because well anchored inflation expectations might have played an important role in preventing inflation from falling further during the crisis. As this model relies on a broad set of variables to disentangle and predict inflation dynamics, it should overlap to a great extent with the information set used by central banks. ${ }^{2}$

10. In the present empirical analysis, three measures of resource intensity use are employed in the Phillips curve equations:

- The output gap has been traditionally included as a measure of economic slack in Phillips curves. However, in practice it is measured with substantial error. ${ }^{3}$ This may be particularly relevant given uncertainty about the impact of the financial crisis on potential output levels.

- The unemployment gap has been found to explain inflation, at least as far as the US case is concerned (Hu and Toussaint-Comeau, 2010). ${ }^{4}$ Moreover, the formulation of the Phillips curve that includes unemployment gaps explicitly allows for a time-varying non-accelerating inflation rate of unemployment (NAIRU) that can act as a shifter to the unemployment-inflation trade-off. ${ }^{5}$ While in principle unemployment gaps should be closely linked to output gaps via the Okun law, this relationship may shift in periods of imbalance or because of economic policy, implying that analyses based on the different measures are warranted.

2. Three main reasons justify the choice of this model. First, although inflation is ultimately a monetary phenomenon, the balance between demand and supply forces is a key determinant of inflationary pressures in the short run. Second, Phillips curves outperform univariate benchmarks (i.e., models based only on past inflation) for forecasting purposes during periods of high resource gaps, either positive or negative (Stock and Watson, 2008 and 2010). Finally, as far as there is a trade off between inflation and economic slack in the short run, Phillips curves continue to be a guide to policy discussions about inflation dynamics (Stock and Watson, 2008).

3. See Beffy et al. (2006) and Koske and Pain (2008) on measurement errors surrounding output gap estimates.

4. Llaudes (2005) suggests that the aggregate unemployment rate may be a distorted measure of the true demand pressure on prices and wages because of the presence of long-term unemployment. The author presents evidence for nineteen OECD countries, showing that the long-term unemployed are less relevant for wage and price formation than the newly unemployed.

5. Controlling for a changing NAIRU is important because a fall in both inflation and unemployment may reflect a decline in the NAIRU instead of reflecting a lack of a significant tradeoff between these variables. 
Figure 1. Annual CPI rate of inflation

United States

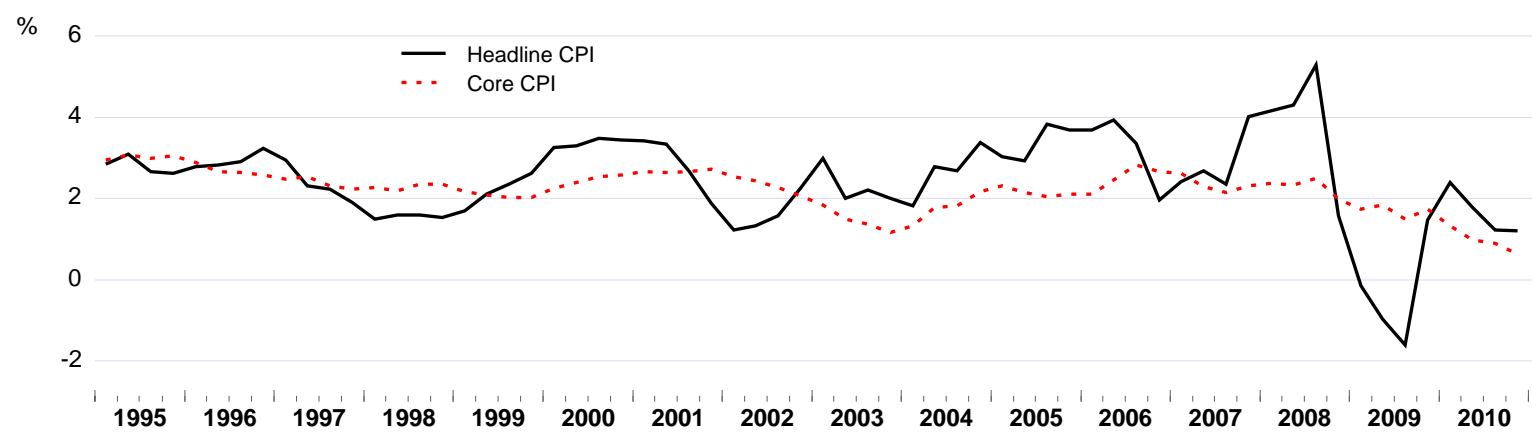

Euro area
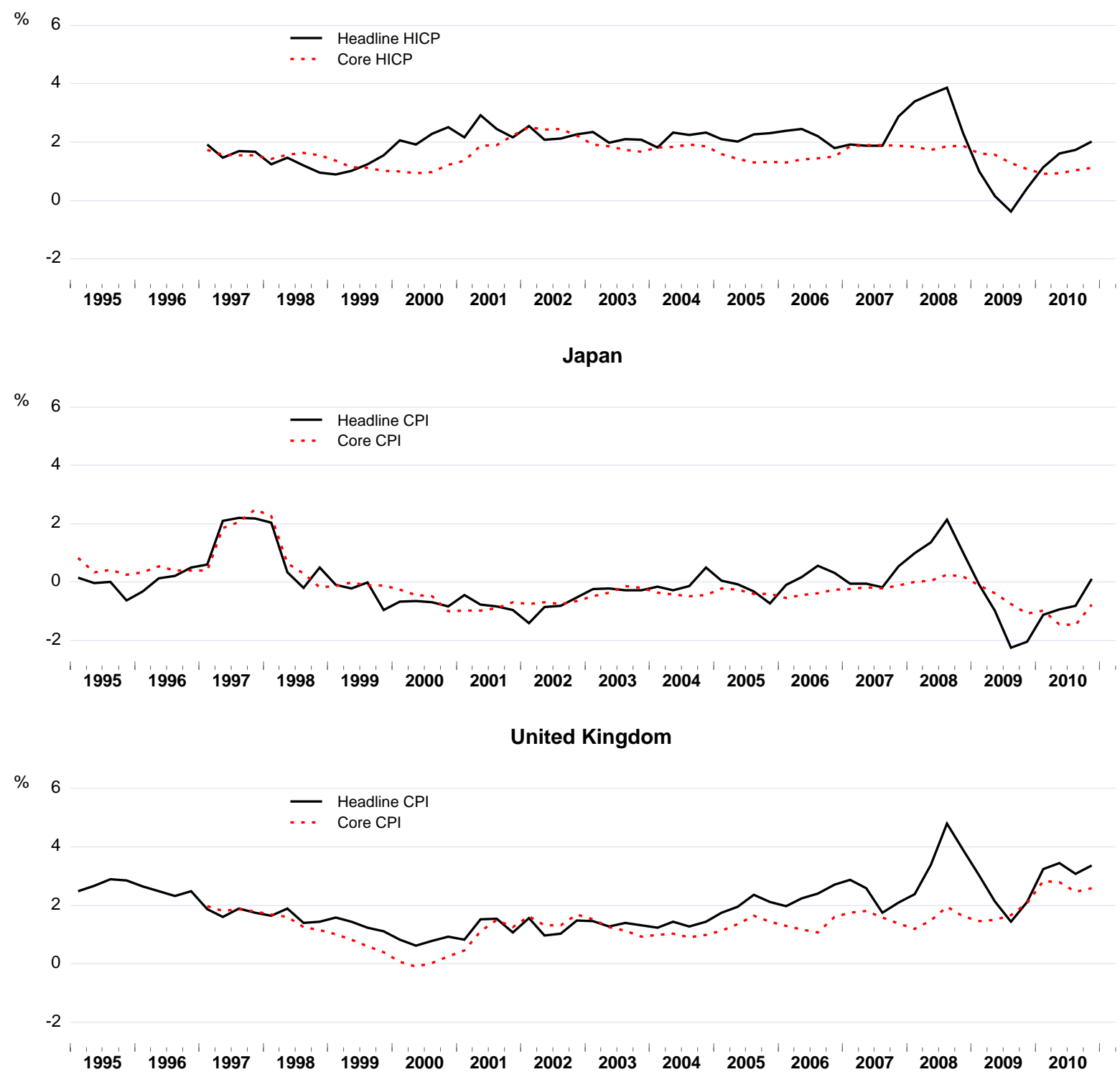

Source: Author's calculations. 
Figure 2. Evolution of underlying inflation measures in the United States

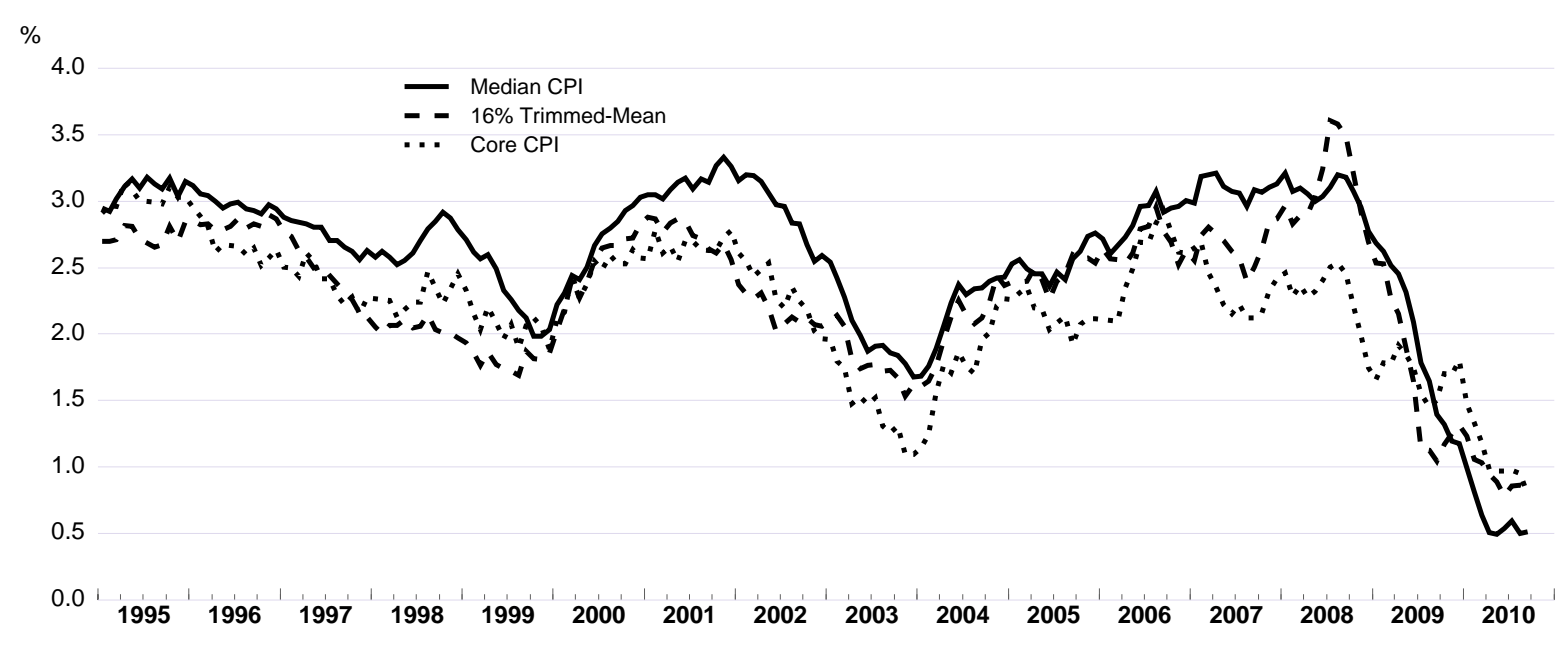

Source: Authors' calculations.

- To allow for the possibility that unemployment affects inflation only during recessions, a variable is included that captures periods of increasing unemployment only (unemployment recession gap). ${ }^{6}$ Essentially, while the standard unemployment gap measure (the difference between the unemployment rate and the NAIRU) varies both during economic expansions and recessions, the unemployment recession gap varies only during downturns. Stock and Watson (2010) argue that using the unemployment recession gap has a series of advantages. First, they find nonlinearities in the relationship between unemployment and inflation only for the standard gap measure, but not when using the unemployment recession gap. Second, they find that linear Phillips curves estimated with the recession gap exhibit less parameter instability than models with conventional gaps. Finally, while the forecasting performance of unemployment gap models improves during recessions (Stock and Watson, 2008), the improvement is the sharpest in the case of the recession gap measure.

11. Though in traditional Phillips curves inflationary pressures are linked to the level of the output or unemployment gaps, the change in economic activity or "speed limit" effect might be relevant as well. Hence, a closing output or unemployment gap may lead to inflationary pressures, even if the level of economic slack in the economy is still high. Such effects might arise because of temporary supply bottlenecks in both physical and human capital that develop when activity is picking up rapidly (Dwyer et al., 2010). As it takes time to install new capacity, temporary supply constraints may arise if demand outpaces capacity build-up. Frictions may also arise in labour markets, for example, because unemployed workers may lose skills during a downturn and require retraining before returning to work, or because of regional or skills mismatches in the source of growth as the output gap closes. It can also arise because insiders dominate wage setting in the short term. Changes in the composition of demand may also put upward pressure on prices in some sectors while considerable spare capacity remains in others.

12. Because commodity prices can influence the inflation process, Phillips curve equations need to account for external shocks as another main driver of inflation. The measure of external shocks typically included in the Phillips curves consists of nominal import prices (Debelle and Wilkinson, 2002 and Kara and Nelson, 2002). In the current study, import price inflation is decomposed into commodity and

6. See Stock and Watson (2010). 
non-commodity price inflation in the econometric specifications. ${ }^{7}$ These external price inflation measures incorporate both currency movements and changes in import prices denominated in foreign currency. Expressing the external measures in domestic currency implicitly accounts for variations in the pass-through of changes in exchange rates and foreign prices to domestic import prices. Evidence surveyed in Pain et al. (2006) shows that the exchange rate pass-through to import prices has declined in the United States and Japan since the 1980s, while in the euro area a break in the pass-through is evident only in a small number of manufacturing industries. ${ }^{8}$

13. The lagged dependent variable is included in Phillips curves to capture inertia in the inflation process. Inertia can be explained by overlapping wage and price contracts, or in the context of the New Keynesian Phillips curve, because a subset of firms set prices according to a backward-looking rule of thumb. ${ }^{9}$ Alternatively, it can be rationalised as incorporating adaptive inflation expectations.

14. Apart from allowing past inflation to have an effect on current inflation, the set of regressors also includes survey measures of short-term inflation expectations. In the context of the New Keynesian Phillips curve, firms operating under nominal rigidities will optimally set prices in a forward-looking manner. Future inflation may also be relevant if workers and firms take into account expected price developments when deciding on changes in nominal wages and setting mark-ups. Including expected inflation on top of lagged inflation among explanatory variables is also important, because changes in policies may cause purely backward-looking Phillips curves to become unstable as the relationship between expectations and economic fundamentals changes.

\section{Data construction}

15. The measures of core inflation used in the empirical analysis of the main text are as follows. For the United States, core inflation is measures as CPI excluding food and energy (core CPI). For the euro area and the United Kingdom, the focus in on the harmonised index of consumer prices excluding food, energy, alcohol and tobacco (core HICP). For Japan, equations are estimated for the consumer price index excluding food and energy. Data are quarterly and seasonally adjusted. A detailed analysis of the determinants of headline inflation in the four economies under consideration is presented in Annex 1.

7. Other studies have used the relative price of imports, computed as the difference between inflation of the deflator for imports and the overall GDP deflator (Stock and Watson, 2008). Still others have used the relative price of food and energy, measured as the ratio between headline and core CPI, as an explanatory variable in both core and headline inflation equations (Barnes and Olivei, 2003, Stock and Watson, 2008). Others have included the exchange rate. See Barnes and Olivei (2003) for specifications for the United States, Musso et al. (2007) for the euro area, and Kara and Nelson (2002) for the United Kingdom.

8. Nevertheless, the estimated equations do not consider the impact of changes in headline inflation on core inflation (second round effects). This is because evidence seems to suggest that short-term movements in the headline inflation rate do not feed into subsequent movements in core inflation, as far as the US case since the mid 1980s is concerned (see Fuhrer et al., 2009).

9. This leads to the so called hybrid Phillips curve (Gali and Gertler, 1999). 
16. Using the indices mentioned before both annual and quarterly annualised inflation rates are constructed. In particular, $h$-period inflation is defined as $\pi_{t}^{h}=h^{-1} \sum_{i=0}^{h-1} \pi_{t-i}$, where $\pi_{t}$ is the quarterly rate of inflation at an annual rate: $\pi_{t}=\left(\left(\frac{P_{t}}{P_{t-1}}\right)^{4}-1\right) * 100$ and $P_{t}$ is the price index in quarter $t .{ }^{10}$

17. Demand or real economic activity variables included in the estimations are the output gap, the unemployment gap, and the unemployment recession gap. The output gap is computed as the percentage difference between actual and potential output, while the unemployment gap is defined as the difference between the unemployment rate and a time-varying non-accelerating inflation rate of unemployment (NAIRU). Both potential output and the NAIRU are estimated by the OECD. The unemployment recession gap, which is intended to capture periods of increasing unemployment during recessions, is computed as the difference between the current unemployment rate and the minimum unemployment rate over the current and previous eleven quarters.

18. Other studies have combined different variables to construct a single index of real economic activity. Variables typically used are e.g. output and income, employment and hours worked, private consumption, housing starts and sales, real inventories, and average hourly earnings, among others, Current values of the index are then used to project inflation one year in the future (Stock and Watson, 1999 and 2002; Bernanke et al., 2005; and Ang et al., 2007). An advantage of using the OECD output and unemployment gap is that projected values of these variables in the Economic Outlook can be used in Phillips curve equation to forecast inflation contemporaneously.

19. The main measures of external shocks in the empirical analysis are percentage changes in nominal commodity and non-commodity import prices (Debelle and Wilkinson, 2002; Kara and Nelson, 2002). ${ }^{11}$ Empirical research has found that import prices have become a more important influence on domestic consumer prices in the OECD area since the mid-1990s (Pain et al., 2006). As in Mourougane and Ibaragi (2004) and Pain et al. (2006), potential issues regarding instability in import price coefficients in the United States, the United Kingdom and Japan are addressed by weighting the quarter-on-quarter annualised rate of growth of import prices by their share in total supply. Hence, the commodity import price variable $\left(w c i p_{t}\right)$ is defined as: $w c i p_{t}=\pi_{t}^{C I} w_{t}^{C I}$, where $\pi_{t}^{C I}$ is quarter-on-quarter annualised commodity import price inflation, and the weight is given by: $w_{t}^{C I}={ }^{M_{t}^{C I}} /\left(G D P_{t}+M_{t}^{C I}\right)$, with $M_{t}^{C I}=$ commodity imports at time $t$. Non-commodity import price inflation $\left(\right.$ wncip $\left._{t}\right)$ is similarly

10. Other studies use the log difference of price indices as a measure of inflation over long time spans, including periods of high inflation, like the 1970s and beginning of the 1980s (Ang et al., 2007; Stock and Watson, 1999 and 2008). Using log differentials in such periods is problematic because this approximation is accurate only when inflation is low, but it underestimates true percentage changes when inflation is high. As in Kara and Nelson (2002), actual percentage changes are used here, rather than a logarithmic approximation.

11. Rather than using Gordon's method to control for supply shocks in general (i.e., including relative prices of food and energy, import prices or the exchange rate), other papers have used Ball and Mankiw's (1995) method. That method uses the skewness of the cross-sectional price change distribution as a proxy for supply shocks. See Mio (2001) for an application to the case of Japan. 
defined. This implies a steadily rising coefficient for the quarter-on-quarter annualised rate of growth of non-commodity import prices $\left(\pi_{t}^{N C I}\right.$ ), in line with the increase in import penetration for this type of products over the past three decades. For commodity imports, which do not exhibit a clear upward penetration trend, it implies a higher coefficient for the quarter-on-quarter annualised rate of growth of commodity imports $\left(\pi_{t}^{C I}\right)$ in periods of temporary increased penetration for these goods, when commodity prices are high. For the euro area, overall import prices are used, including intra-regional trade, because no decomposition between commodity and non-commodity imports, and between intra and extra-regional imports, are available for this economy. ${ }^{12}$

20. This empirical study uses survey measures rather than break-evens or realised inflation as a measure of inflation expectations. While break-even expected inflation rates are available over a too short time span to be used in the econometric analysis, using realised future inflation has a number of recognised drawbacks. ${ }^{13}$ For the United States, the Survey of Professional Forecasters (SPF) by the Federal Reserve Bank of Philadelphia is used, which collects information on seasonally-adjusted quarter-on-quarter inflation expectations for the headline CPI. ${ }^{14}$ The survey is conducted in the middle of every quarter and participants are primarily from the business sector. An advantage of the SPF is that at each quarter respondents are asked to forecast quarterly inflation rates over the next year. This is very useful from a forecasting point of view because it allows using expectations for quarterly inflation rates when forecasting actual quarterly inflation over the next year. ${ }^{15}$ Surveys of professionals are also used for the euro area, which are available on a quarterly basis since 1999, immediately following the establishment of the single currency. Expectations are for year-on-year percentage changes in the Harmonised Index of Consumer Prices published by Eurostat. ${ }^{16}$ For the United Kingdom, the Barclays BASIX survey of one-year-ahead inflation expectations from the general public is used. The survey is quarterly and is available since the fourth quarter of $1986 .{ }^{17}$ In the case of Japan, rather than using professional or general public forecasts, the Bank of Japan Tankan survey on enterprises regarding retail price expectations over the next quarter is employed, which is closer to consumer price expectations than using the all industries component of the survey. In contrast to the previous surveys, which report a quantitative measure of inflation expectations,

12. That the measure of import prices includes intra-euro area trade may induce some endogeneity in this coefficient if a price shock to euro area consumer prices affects simultaneously export and import prices from other members. Other studies have used the nominal effective exchange rate and oil prices as measures of supply side shocks (Musso et al., 2007). From a forecasting point of view, an advantage of using import price series is that the OECD projects this variable, which can help to predict future inflation more accurately. Exchange rates and oil prices are in contrast assumed to follow a random walk process, being constant over the projection period.

13. These include assuming perfect foresight of economic agents, problems of weak instruments, mixing the roles of future and lagged inflation when the latter act as instruments, and inducing a measurement error whose volatility may distort inference. See Zhang et al. (2009).

14. While PCE inflation features more prominently in policy work, inflation expectations for headline and core PCE are only available since 2007.

15. Other surveys collect expectations over longer time periods (University of Michigan Inflation Expectation survey), are available on a less frequent basis (Federal Reserve Bank of Philadelphia Livingston Survey). For more details, see Thomas (1999).

16. See Mestre (2007) for measures of inflation expectations in the euro area.

17. Other surveys, like the YouGov/Citigroup or the Bank of England/GfK NOP Inflation Attitudes Survey are available over a much shorter time span (since 2005 and 1999, respectively). 
the Tankan survey only reports a diffusion index, i.e. the percentage of answers to a question of whether inflation will increase or fall. ${ }^{18}$

21. The literature has frequently estimated econometric models where the horizon at which inflation expectations are measured (1-year ahead) differs from the empirical model (annualized quarter-on-quarter inflation rates), as is the case here for the euro area and the United Kingdom. The literature has also estimated core Phillips curve models including expected inflation measures that refer to headline inflation, because inflation expectations for core inflation are not available, and when they are (like in the case of the United States) it is for a very short period of time. See Eliasson (2001), Dwyer et al. (2010) and Stock and Watson (2010) among others. Similar choices have been made here when necessary.

\section{The choice of estimating period}

22. Descriptive statistics for the inflation measures over two sample periods (1960-1980 and 1981-2010) are reported in Table 1. Inflation in major OECD economies was higher and more volatile during the 1960-1980 period than over the last three decades, largely driven by the oil shocks during the 1970s. In the United States, inflation, as measured by the PCE deflator (both headline and core), was lower and less volatile than the CPI measures. ${ }^{19}$ And while core inflation was lower than headline (for both indices) over the first period, the reverse is true for the second sample. This result is heavily influenced by the recent crisis, with the strong impact of the commodity price contraction on headline inflation. Regarding volatility, core inflation measures tend to be less volatile than headline measures in the United States. In the case of Japan, core inflation has been higher and less volatile than headline inflation for both sample periods. In the case of the United Kingdom and the euro area, data are available for a shorter time span. The core price index is available since 1996 in the former, while both core and headline price indices are available since 1990 in the latter. Comparisons with respect to the 1960-1980 period cannot therefore be reported in these cases. Nevertheless, for the most recent period for which data are available, core inflation has been lower and less volatile in the two economies.

23. Empirical evidence shows that persistence in the inflation process fell at the beginning of the 1980s, at least in the case of the United Kingdom and the United States. In particular, Halunga et al. (2009) found that monthly inflation changed from being integrated of order one to being stationary in the third quarter of 1982 in the United States, and in the fourth quarter of 1981 in the United Kingdom. ${ }^{20}$ In turn, less persistent inflation has been found to facilitate the forecasting process. Stock and Watson (1999) show that Phillips curves for the United States estimated for stationary models since the beginning of the 1980s, when inflation became less persistent, have a better out-of-sample forecasting performance than unit root models since the 1950s. Also for the United States, Fuhrer et al. (2009) show that the out-of-sample forecasting performance of the Phillips curve improves dramatically when accounting for a change in parameters in the 1980 s.

18. Quantitative measures of inflation expectations over the next year from the Opinion Survey on the General Public's Views and Behaviour by the Bank of Japan, the Monthly Consumer Confidence Survey by the Cabinet Office, and the EPA/ESP Monthly Forecast Survey are only available since 2004.

19. That PCE inflation is, on average, lower than CPI inflation may be partly due to its use of a chain weighting scheme in contrast to CPI which uses a fixed basket (Ang et al., 2007).

20. The authors also find a break in the data generating process from stationarity to a unit root in January and December 1973 in the United States and the United Kingdom, respectively. Estimations run from January 1955 to December 2006 for the (seasonally adjusted) US consumer price index (CPI), and the retail price index (RPI) in the United Kingdom. 
24. The choice of the sample periods retained in the econometric estimations is based on the previous discussions regarding volatility and persistence in the inflation process as well as on data availability. In the case of the United States the sample period for all inflation measures starts in the third quarter of 1982, when consumer inflation became less persistent. In the case of Japan, the focus is on the same sample period as in the United States. In the United Kingdom, the sample period for headline inflation starts in the first quarter of 1981, when inflation is estimated to have become less persistent, and in the first quarter of 1996 for core inflation, when data for this variable started to be collected. Finally, in the euro area, the estimations start in the first quarter of 1999, when data on quantitative measures of expected inflation started to be gathered by the European Central Bank. Excluding the late 1970s and the very beginning of the 1980s from the sample is important to avoid extremely high volatility and structural breaks biasing the results. The sample ends in the third quarter of 2010 in the United States, and in the second quarter of 2010 in the remaining countries.

Table 1. Descriptive statistics for inflation

$\mathrm{Q} / \mathrm{Q}$ annualised rates of inflation

\begin{tabular}{lcccc}
\hline & & \multicolumn{2}{c}{ Sean } & \multicolumn{2}{c}{ Deviation } \\
\hline & $\mathbf{1 9 6 0 - 1 9 8 0}$ & $\mathbf{1 9 8 1 - 2 0 1 0}$ & $\mathbf{1 9 6 0 - 1 9 8 0}$ & $\mathbf{1 9 8 1 - 2 0 1 0}$ \\
\hline United States & & & 3.92 & 2.38 \\
Headline CPI & 5.35 & 3.27 & 3.62 & 1.91 \\
Core CPI & 5.05 & 3.38 & 3.25 & 1.80 \\
Headline PCE & 4.79 & 2.89 & 2.75 & 1.61 \\
Core PCE & 4.40 & 2.97 & 5.95 & 1.91 \\
\hline Japan & & & 5.62 & 1.60 \\
Headline CPI & 7.37 & 0.82 & & 3.06 \\
Core CPI & 8.75 & 1.00 & 8.21 & 0.85 \\
\hline United Kingdom & 14.71 & 3.36 & & 1.26 \\
Headline CPI (1) & & 1.36 & & 1.13 \\
Core CPI (2) & & 2.32 & & \\
\hline Euro area & & 2.16 & & \\
Headline CPI (3) & & & & \\
Core CPI (3) & & & & \\
\hline
\end{tabular}

Notes: 1) Headline CPI data start in the second quarter of 1975. 2) Core CPI data start in 1996. 3) Data start in 1990.

Source: Authors' calculations.

\section{Unit root tests}

25. In order to correctly disentangle the main drivers of inflation in major OECD economies, it is important to know whether it is appropriate to model inflation in levels or in first differences. Moreover, when modelling inflation over long time spans as here, it is also relevant to detect the presence of breaks in the deterministic components of the data generating process, the omission of which would seriously bias the estimated coefficients and lead to misleading economic forecasts. Annex 2 presents the results of the estimation of unit root tests allowing for the possibility of such breaks in the inflation measures used in the empirical analysis. ${ }^{21}$

21. The choice of the sample period excludes major structural breaks in the slope of the Phillips curve. 


\section{Econometric specification}

26. The specification of the Phillips curve for the euro area, the United Kingdom and the United States follows Fuhrer et al. (2009):.22

$$
\pi_{t}=\delta+\phi(L) \pi_{t-1}+\beta \pi_{t}^{e}+\mu(L)\left(w_{c i p}\right)+\lambda(L)\left(\text { wncip }_{t}\right)+\alpha(L) x_{t}+\varphi(L) \varepsilon_{t}
$$

where $\pi_{t}$ and $\pi_{t-1}$ are the annualised quarter-on-quarter core inflation rate at time $t$ and $t-1, \pi_{t}^{e}$ is the expected inflation rate at time $t, w_{c i p}$ and wncip $_{t}$ are the quarter-on-quarter annualised rate of growth of commodity and non commodity import prices, and $x_{t}$ is a measure of economic activity (the output gap, $y_{t}$, the unemployment gap, $u_{t}$, or the unemployment recession gap, $\left.u r_{t}\right) . \delta$ is a constant, and $\phi(L)$, $\mu(L), \lambda(L), \alpha(L)$, and $\varphi(L)$ are lag polynomials of potentially different orders.

The Phillips curve differs slightly in the case of Japan and follows Stock and Watson (1999):

$$
\pi_{t}^{4}=\delta+\phi(L) \pi_{t-4}+\beta \pi_{t-4}^{e}+\mu(L)\left(w_{c i p}\right)+\lambda(L)\left(w_{n c i p}\right)+\alpha(L) x_{t}+\varphi(L) \varepsilon_{t}
$$

Where $\pi_{t}^{4}$ is the annual inflation rate at time $t$. The remaining variables follow the same definitions as before. As it is apparent from comparing equation (1) and (2), the only difference is that past and expected inflation appear lagged four quarters in the equation for Japan. The different specification in Japan is because the expected inflation variable is measured as a diffusion index with respect to past inflation, and hence lacks of a direct numerical correspondence with the rate of inflation. This property makes it very hard to assume a path for the future evolution of inflation expectations, which is necessary to project inflation. Hence, the option of using expected inflation values in time $t$ to project inflation at time $t+4$ is used here.

27. Another difference from the standard specification regards the inclusion of the inverse of the unemployment rate $\left((1 / U R)_{t}\right)$ rather than the unemployment gap. This choice is made because empirical evidence for this country shows that there is a nonlinear relationship between inflation and the unemployment rate, implying that it is difficult to drive inflation lower when it is already very low because the unemployment rate is high. ${ }^{23}$ In contrast, evidence shows the absence of such nonlinearity in the case of the output gap (Cabinet Office, 2003).

28. The polynomial structure for the error term $\left(\varepsilon_{t}\right)$ in equations (1) and (2) that accounts for a moving average in the error component of the estimating equation was found to improve the performance of the Phillips curves by reducing error autocorrelation and eliminating heteroscedasticity in some cases. This is not surprising since inflation tends to display a highly noisy behaviour.

22. Nevertheless, this study differs from Fuhrer et al. (2009) in the use of weighted import prices (both commodity and non-commodity imports) and the inclusion of expected inflation in the estimated equations.

23. This feature is important when trying to explain Japanese inflation over the past few years. See Mourougane and Ibaragi (2004) for empirical evidence, and see Shirota (2007), Yamamoto (2008) and De Veireman (2007) for explanations about why deflation did not accelerate over the increasing unemployment period of 1998-2002. See also the discussion below about the existence of nonlinearities between inflation and economic activity. 
29. Moreover, given that in the long run inflation is a monetary phenomenon, it would be expected that the coefficients of lagged inflation and inflation expectations sum to 1 , so that inflation is neutral with respect to real variables and the Phillips curve is vertical in the long run (dynamic homogeneity assumption). ${ }^{24}$ As in Zhang et al. (2009), this restriction is tested rather than imposed on the behaviour of inflation.

30. Regarding the presence of speed-limit effects, restricted coefficients are reported when the null hypothesis is not rejected that the coefficients of lagged economic activity are equal but opposite in sign. ${ }^{25}$ In some other cases, a simple decomposition of the lag structure of parameters shows the presence of speed-limit effects. ${ }^{26}$

31. Based on the unit root test results presented in Annex 2, variables will enter the Phillips curves as follows:

- Core measures of consumer inflation are modelled in levels in the United Kingdom and in levels around breaks in the United States and in the euro area.

- Variables are modelled in first differences in Japan and for core PCE in the United States, also allowing for breaks in the latter case. ${ }^{27}$

32. Dummy variables have been included in the equations to account both for tax changes and the break in trends detected before. Two dummy variables were included in the case of Japan and the United Kingdom to account for the consumption tax hikes in the second quarter of 1989 and 1997 in the former, and for the decrease in the VAT in the fourth quarter of 2008 and the subsequent increase in the first quarter of 2010 in the latter. Regarding breaks in trends, in the case of core PCE inflation in the United States two impulse dummy variables were included starting in the second quarter of 1990 and the fourth quarter of 2001. For core CPI in the same country, although tests detected a break in the inflation process at the beginning of 2004, the lagged eight quarter moving average of inflation was included as a proxy for a structural break, because including a deterministic break made all the parameters to be insignificant and have unrealistic values. ${ }^{28}$ For the euro area, there is the need to account for a structural break in the fourth quarter of 1999 for core CPI inflation. ${ }^{29}$

24. For inflation targeters, this vertical long-run Phillips curve implies that it is not possible to drive unemployment down by increasing the inflation target level.

25. For example, in the case of a polynomial with only one lag of economic activity, $\alpha(L) x_{t}=\alpha_{1} x_{t}+\alpha_{2} x_{t-1}, \quad$ a speed-limit effect requires that $\alpha_{2}=-\alpha_{1}$, So that $\alpha(L) x_{t}=\alpha_{1}\left(x_{t}-x_{t-1}\right)=\alpha_{1} \Delta x_{t}$.

26. For example, in the case of headline CPI inflation in the United States (results reported in Annex 1), the impact of the unemployment recession gap can be easily decomposed as follows: $-1.21 u r_{t}+0.98 u r_{t-1}=-0.23 u r_{t}-0.98 \Delta u r_{t}$, where $\Delta$ is the first difference operator.

27. The unit root hypothesis amounts to imposing the restriction that $\phi(1)=1$ in equations (1) and (2).

28. A similar approach was followed by Fuhrer and Olivei (2010).

29. Another way to account for the effect of changes in net indirect taxes is to use the GDP deflator at factor costs (Turner, 1995). 
33. Finally, it is important to note that a linear form for the Philips curves estimated here was preferred to changing coefficients or nonlinear models to forecast inflation in the four economies under consideration. A linear specification was preferred because evidence seems to suggest that the major change in the slope of the Phillips curve occurred at the beginning of the 1980s in the four countries under consideration, while being relatively more stable afterwards (Figure 3 ). ${ }^{30}$ Moreover, the model that includes the unemployment recession gap variable can account for potential non-linearities in the link between inflation and unemployment, because Stock and Watson (2010) found that nonlinearities are present only when a standard unemployment gap measure is included in the regressions. Regarding external shocks, because previous literature has found a strong role for global forces in shaping domestic inflation outcomes, import price changes have been weighted by their share over total supply to account for the potential instability in the import price coefficient. ${ }^{31}$

\section{Estimation and results}

34. This section presents the results of estimating the Phillips curve equations using data until mid 2010 for the four economies under consideration. The most general model is estimated with four lags of every explanatory variable, the exception being core CPI and core PCE inflation in the United States, where including up to eight lags of import prices (both commodity and non-commodity) was found to improve substantially the performance of the econometric models. More parsimonious representations of the Phillips curves were found following a model selection approach based on a general-to-particular selection of variables and joint significance tests, given that lags of macroeconomic variables tend to be highly correlated, reducing their individual statistical significance. The equations are estimated by maximum likelihood techniques and the results are presented in Table 2. Diagnostic tests for the equations are presented at the end of the table.

35. The overall historical tracking performance of the models is quite satisfactory for the United States and Japan, (Figures 4 to 6). In contrast, Phillips curve models perform relatively poorly in explaining the historical evolution of core inflation measures in the euro area and the United Kingdom (Figures 7 and 8). In the euro area, the model misses most of the variation in core inflation but captures its central tendency. In the United Kingdom, however, the model tracks remarkably well the evolution of core inflation during the recent financial crisis. The results for the United States appear to be the most robust. All in all, and with some exceptions, the key explanatory variables tend to be statistically significant and have the expected signs. Moreover, the null hypothesis of dynamic homogeneity could not be rejected, implying a vertical long-run Phillips curve. In the short to medium run, however, economic activity affects inflation and monetary aggregates are not powerful drivers of inflation (Stock and Watson, 2010). A limitation of the Japanese equation is that the adjustment coefficients point to a questionable dynamic pattern.

30. See Stock and Watson (2010) and Fuhrer et al. (2009) for evidence of a break in the Phillips curve for core PCE inflation in the United States, and Haldane and Quah (1999) and Musso et al. (2007), for evidence regarding the United Kingdom and the euro area, respectively.

31. As mentioned before, this implies a steadily rising coefficient for the quarter-on-quarter annualised rate of growth of non-commodity import prices, while it implies a higher coefficient for the quarter-on-quarter annualised rate of growth of commodity imports in periods of high commodity prices. Weighting import price changes by openness should capture most of the changes in these parameters. 
Figure 3. Phillips curves in selected OECD economies
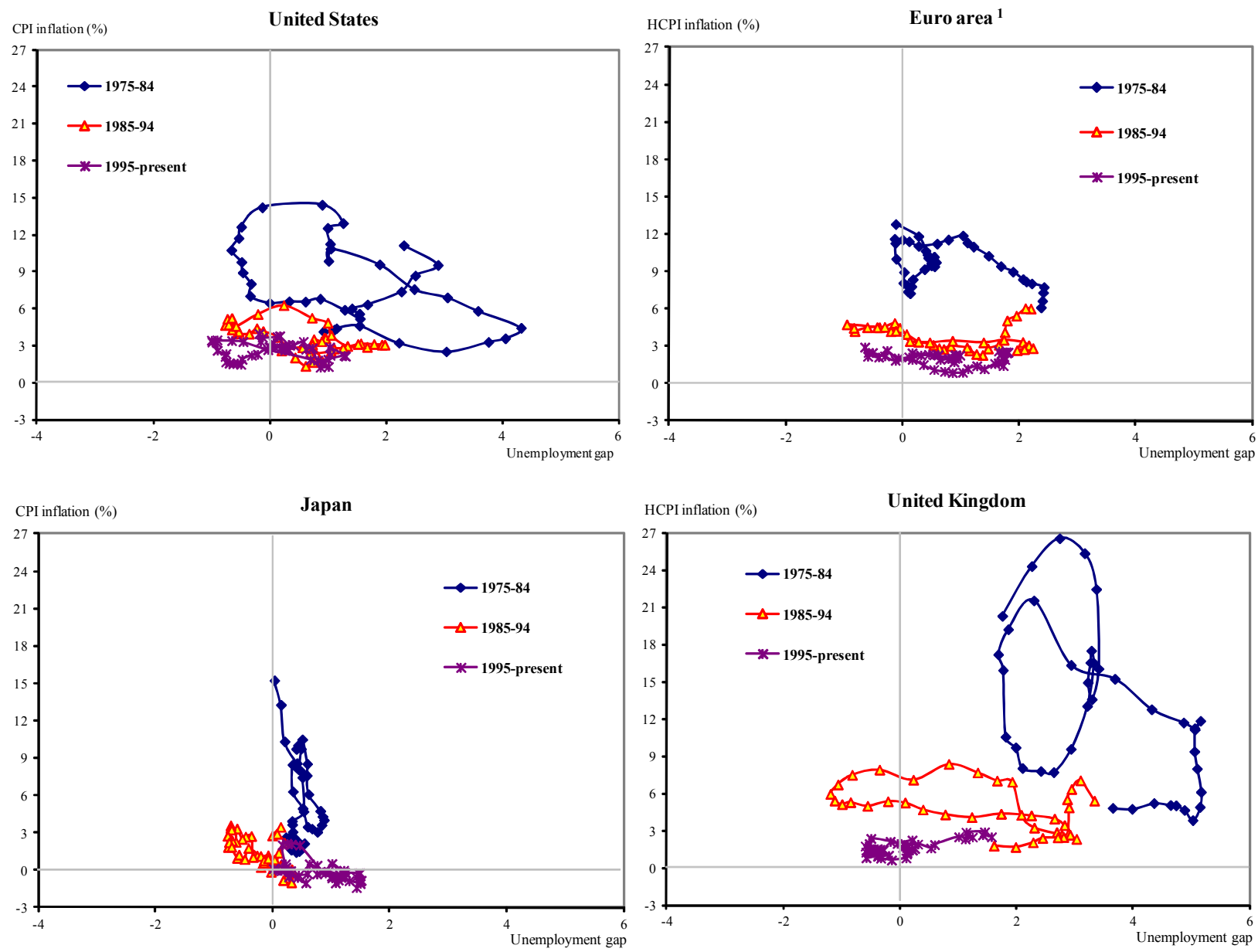

Note: The unemployment gap is the difference between the unemployment rate and the NAIRU (as estimated by the OECD).

1. For the euro area, CPI is shown prior to 1991. Western Germany is used in place of total Germany to calculate the aggregate euro area prior to 1991 .

Source: OECD

Source: Authors' calculations.

\section{Economic activity}

36. The econometric results generally confirm the importance of resource intensity use in the inflation process. They also indicate that slack generates a smaller fall in the inflation rate in the United States than the euro area, when focusing on the unemployment gap as a measure of resource slack (Figure 9). With respect to the unemployment recession gap, statistically significant results are only obtained for the United States and Japan, suggesting that an increase in the unemployment rate of 1 percentage point in a recession reduces the inflation rate by 0.2 percentage points in the United States, and by a 1 percentage point in Japan after three years. 
Table 2. Models for Core CPI inflation

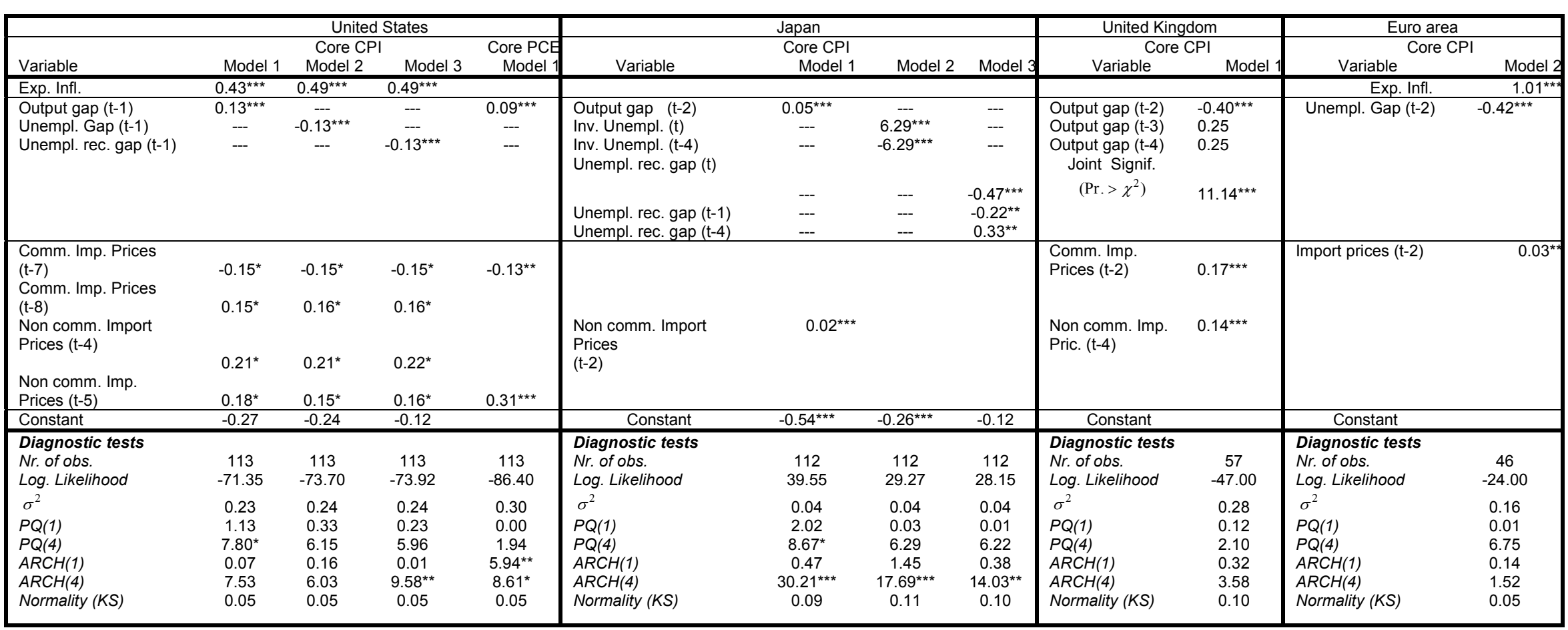


Figure 4. Actual and fitted values for core CPI inflation in the United States

Dep. Var.: Q/Q annualised core CPI inflation (per cent)
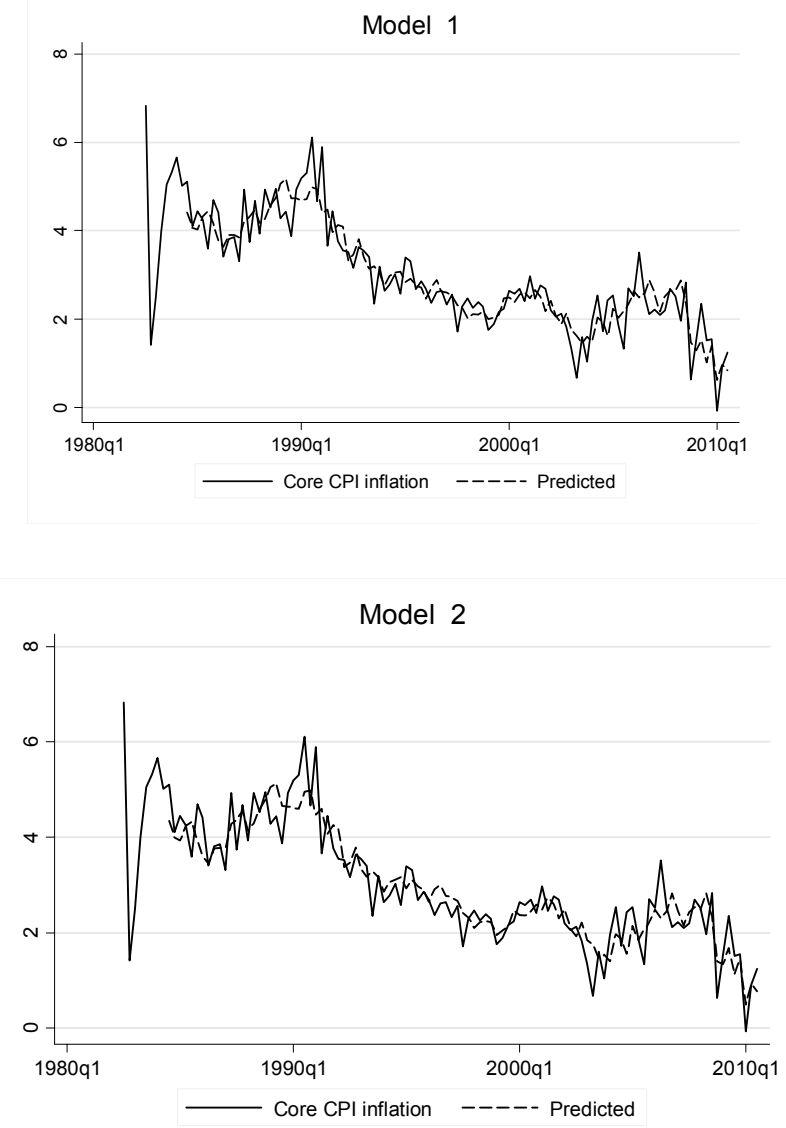

Model 3

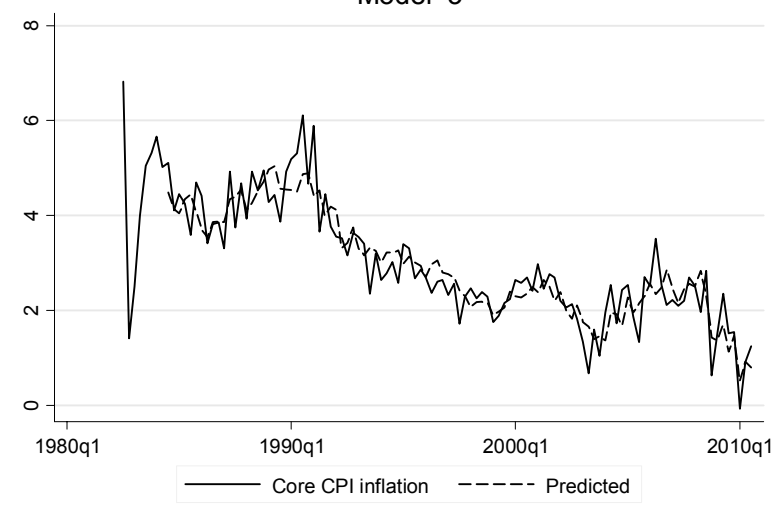

Note: Fitted values are obtained from Models 1, 2 and 3 reported in Table 2. Source: Authors' calculations. 
Figure 5. Actual and fitted values for core PCE inflation in the United States

Dep. Var.: Q/Q annualised core PCE inflation (per cent)

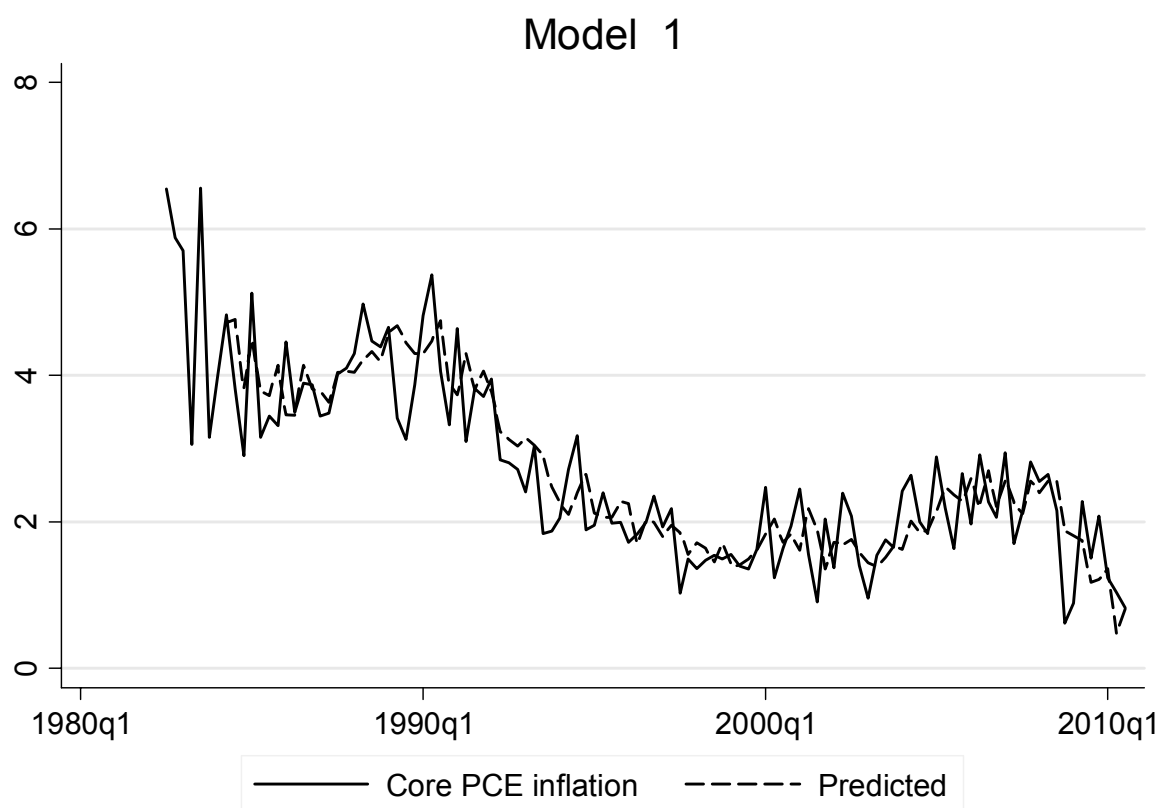

Note: Fitted values are obtained from Model 1 estimated in Table 2.

Source: Authors' calculations.

Figure 6. Actual and fitted values for core CPI inflation in Japan

Dep. Var.: $\mathrm{Y} / \mathrm{Y}$ core $\mathrm{CPI}$ inflation (per cent)

Model 1

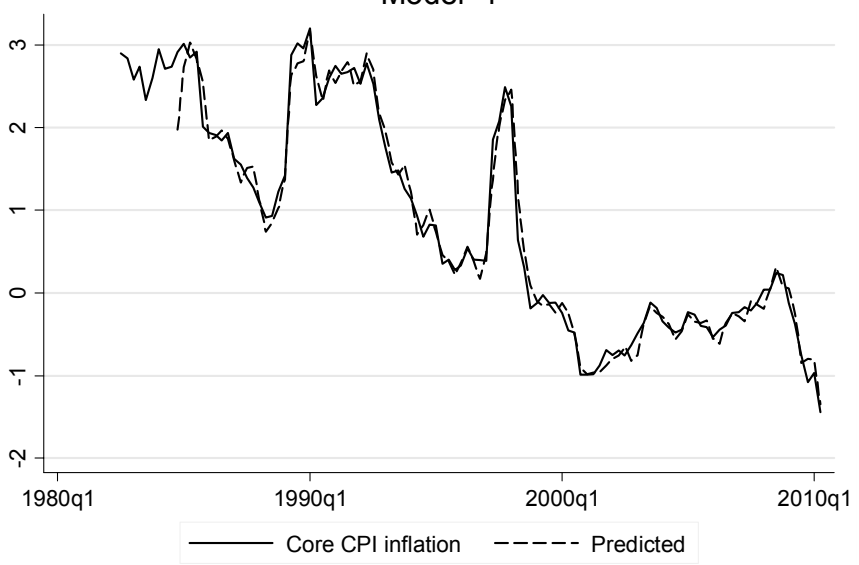


Model 2

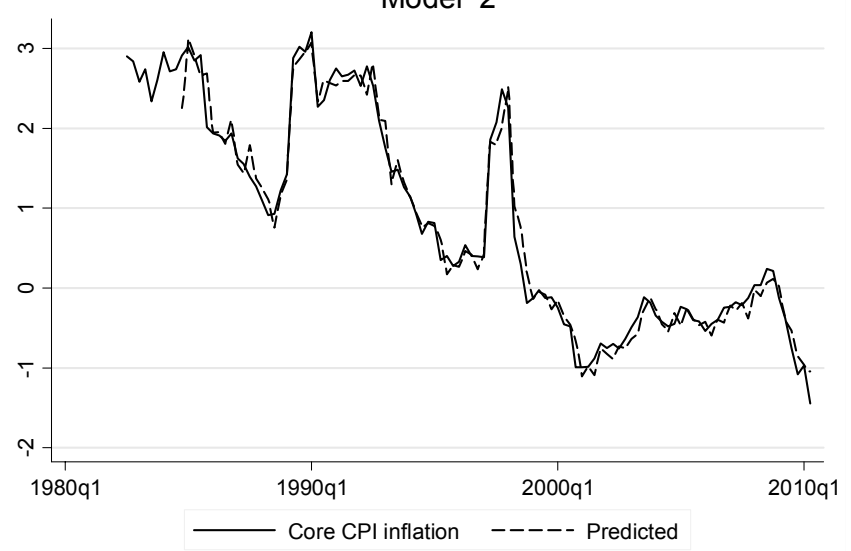

Model 3

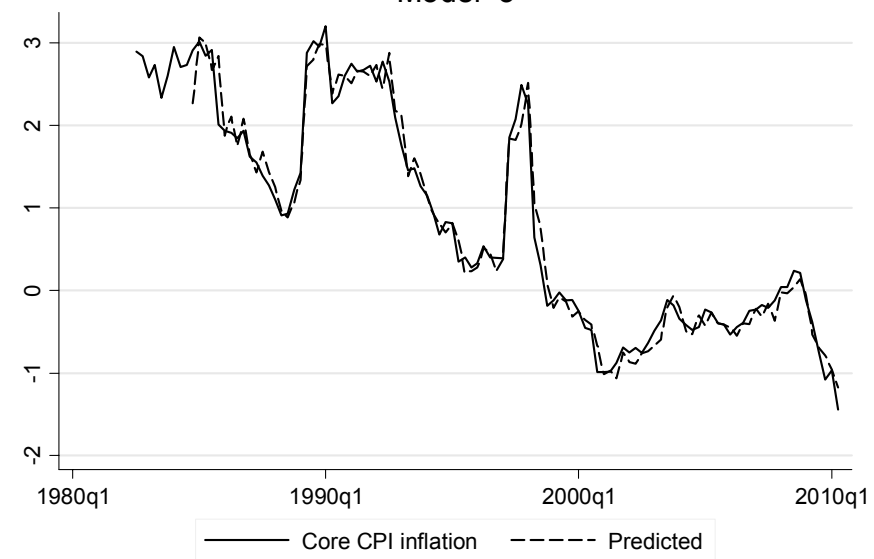

Note: Fitted values are obtained from Models 1, 2 and 3 reported in Table 2.

Source: Authors' calculations.

Figure 7. Actual and fitted values for core CPI inflation for the United Kingdom

Dep. Var.: annualised Q/Q core CPI inflation (per cent)

Model 1

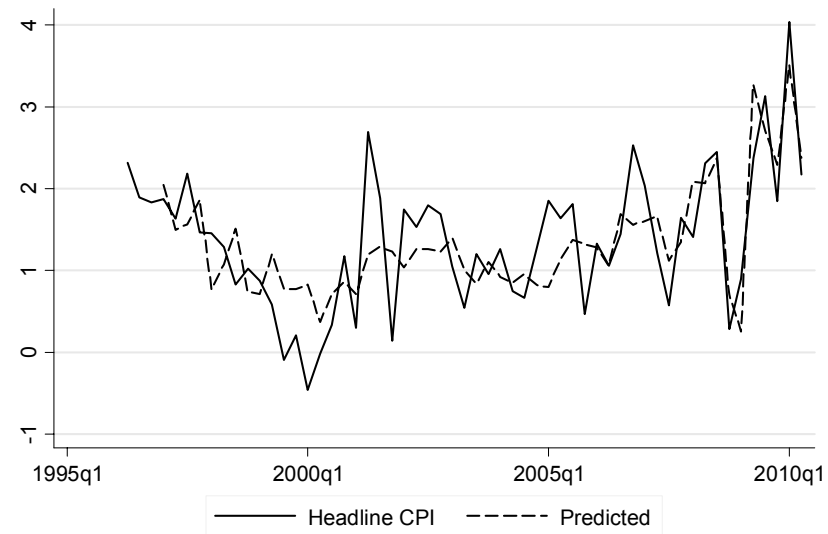

Note: Fitted values are obtained from Model 1 reported in Table 2.

Source: Authors' calculations. 
Figure 8. Actual and fitted values for core CPI inflation for the euro area

Dep. Var.: annualised $Q / Q$ core inflation (per cent)

Model 2

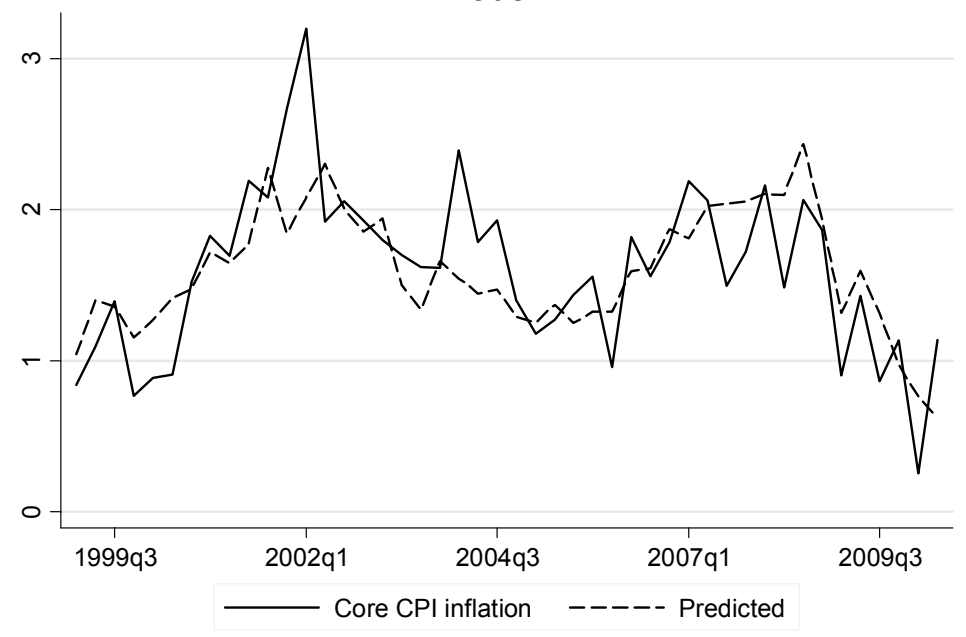

Note: Fitted values are obtained from Model 2 reported in Table 2.

Source: Authors' calculations.

Figure 9.Response of core CPI inflation to economic activity and expected inflation shocks

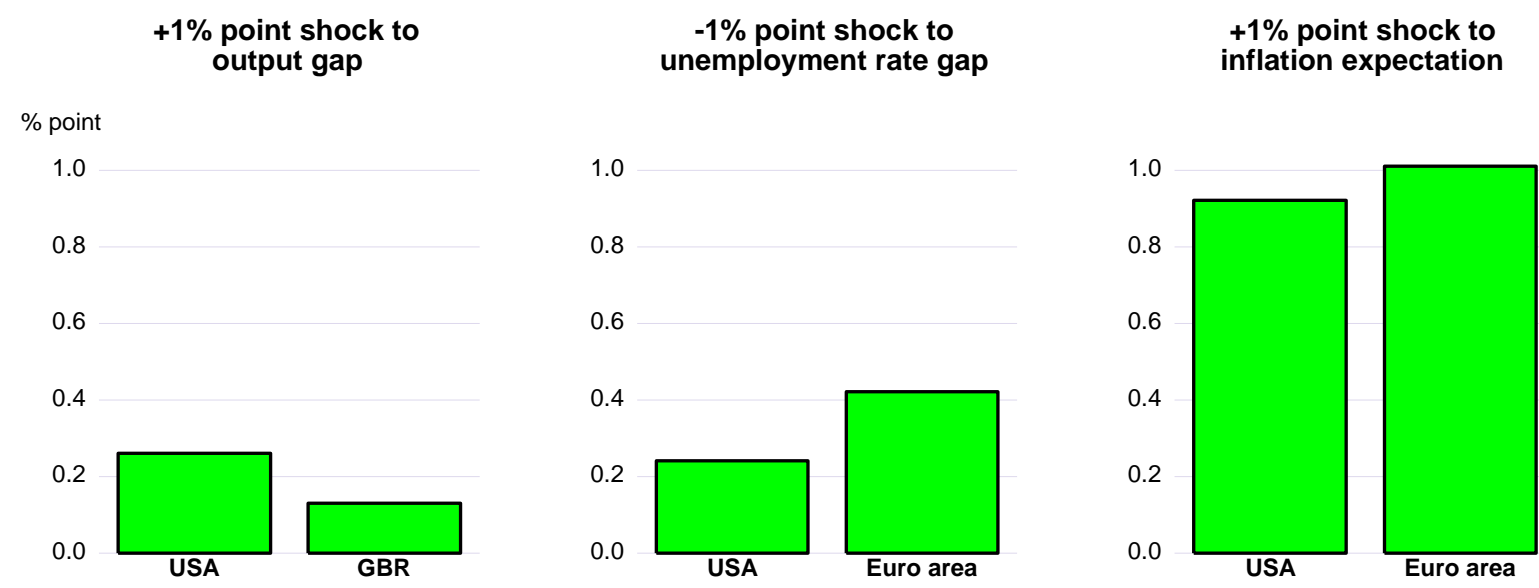

Note: The figures show the response of core inflation after twelve quarters to a permanent shock to the output and unemployment gap and inflation expectations.

Source: Authors' calculations. 
37. There is some evidence of the change in resource intensity use in addition to its level influencing the inflation process in the four economies under consideration. However, such speed-limit effects seem to be confined mainly to headline inflation, as described in Annex 1, suggesting that they are particularly relevant for the volatile elements of the price index.

\section{Commodity and non-commodity import prices}

38. The regression results confirm that a permanent shock to commodity import price levels (i.e. a temporary shock to import price inflation) would affect inflation developments, though the impact on core inflation seems relatively small. Nevertheless, the impact appears to be relatively strong in the euro area and comparatively mild in the United Kingdom and the United States.

\section{Expected inflation and persistence}

39. The empirical results give strong support for the conjecture that inflation expectations over the near term, as derived from surveys, play a key role in the inflation process in the United States and the euro area (Figure 4). Short-term inflation expectations are a key driver of core CPI inflation in the United States, though not for core PCE inflation. ${ }^{32}$ In the case of the euro area, expected inflation was also found to be significant in explaining core inflation. ${ }^{33}$ In the case of Japan and the United Kingdom, expected inflation was not found to be statistically significant. ${ }^{34}$

40. Inflation also displays some degree of persistence, as gauged by the significance of lags of the dependent variable in most of the equations. This can be measured by the impact at different horizons of a $1 \%$ transitory shock to past inflation. Based on the estimated equations, for core inflation, persistence looks higher in the United Kingdom than in the euro area, with the United States in between (Table 2).

\section{Decomposing the contribution of explanatory variables to inflation outcomes}

41. Decomposing the contribution of explanatory variables on inflation in each of the countries under consideration can help answering the question of why the reaction of underlying inflation has been so muted during the crisis in spite of the large shock in economic activity. In order to disentangle the main drivers of inflation, the contribution of explanatory variables on inflation levels is decomposed since the recession started in the last quarter of 2007, and up to the third quarter of 2010. The results of the empirical analysis for core inflation measures suggest that anchored inflation expectations played a key role in holding up inflation in the euro area and the United States. Inflation persistence also played an important role in the United States, Japan and the United Kingdom. Economic slack has been putting growing downward pressure on inflation since late 2008 and in 2009, though its impact looks relatively small (Figure 10).

32. One reason why expectations are not significant for core PCE inflation may be because the SPF survey refers to CPI inflation expectations. Core PCE inflation expectations started to be collected only since 2007.

33. In the case of the United States, a significant forward-looking term is also reported by, among others, Galí and Gertler (1999), Sbordone (2002), Galí et al. (2005), and Kleibergen and Mavroeidis (2009), but not by Fuhrer and Moore (1995), Fuhrer (1997), and Rudd and Whelan (2005). Paloviita and Virén (2005) found that inflation expectations are a key ingredient of the inflationary process in the euro area.

34. For Japan, this might be due to the fact that inflation expectations are included with a four period lag in the estimations, while the outturn for inflation is affected by large shocks occurring since the time inflation expectations were formed one year ago. When included in contemporaneous form, Mourougane and Ibaragi (2004) do find that inflation expectations are statistically significant. 
42. The models do not account for some factors that have become relatively more important for inflation during the crisis. Housing costs, though small, have exerted downward pressure on inflation over this period, especially in the United States and, to a lesser extent, in the euro area and the United Kingdom. Statistical and economic factors explain the different behaviour of housing costs across countries. First, the harmonised index of consumer prices adopted by EU countries excludes owner's equivalent rent from the index (Box 2). Second, the scale of the boost and subsequent burst in the housing market is larger in the United States than in the euro area and the United Kingdom.

43. Another factor that is not systematically taken into account in the analysis are changes in indirect taxes, both VAT and excise duties. These have affected price developments, though the exact pass-through is hard to gauge in practice. In the United Kingdom, national authorities estimate that half of the January 2010 re-establishment of the VAT to its previous level has been passed through to the CPI (Bank of England, 2010). In the same vein, the hike in the tobacco tax in the spring of 2009 is also expected to have contributed to prevent a deceleration of goods prices in the United States. In the euro area, fiscal measures such as hikes in VAT, other indirect taxes and administered prices are estimated to have added $1 / 2$ percentage point to HICP inflation between December 2009 and August 2010 (ECB, 2010). By contrast, the introduction of subsidies for high school tuition fees increased the rate of deflation in Japan in 2010.

\section{Box 2. Cross-country differences in the treatment of housing costs in consumer price indices}

Housing costs are an integral and important part of consumption so that in principle they are included in consumer price indices, irrespective of whether households rent or own their home. In the latter case of owneroccupied dwellings, however, the implementation of this principle poses a certain number of statistical difficulties as there is no directly observable market rent available. In a large number of countries, including the United States and Japan, an imputation is made to incorporate a component that tracks owner-occupied housing costs as closely as possible. For instance, in the US case, the Bureau of Labour Statistics prices owner-occupiers' equivalent rents on the basis of how much renters have to pay for equivalent properties. However, in the European Union, the harmonised index of consumer price (HICP) has been historically constructed with the requirement that it should not include imputed components. Owner-occupiers' housing costs have been excluded from the index on the basis of this rule, pending the definition of a method that would enable their inclusion. Although the inclusion of this component was identified as a priority by Eurostat from 1998 and a pilot experiment with the use of property prices net of land prices has been carried out, no date for the coverage of owner-occupied housing cost in the HICP has been announced so far. As a result of this situation, the weight of housing rent in the core index is $8 \%$ in the euro area and $7 \%$ in the United Kingdom (which also uses the HICP as its national CPI), compared to $18 \%$ in the United States and $25 \%$ in Japan.

The differences in the coverage of price indices can have consequences for the dynamics of reported inflation. Firstly, the exclusion of a large share of property-related costs means that HICP-based inflation rates will be less sensitive to housing developments than the US and Japanese price indices. Secondly, because rents evolve more smoothly than many other consumption items (even following large house price movements), their lower weight in the HICP should work to make the HICP more volatile than other indices, all other things being equal.

Source: Cournède (2005). 
Figure 10. Contribution to core CPI inflation
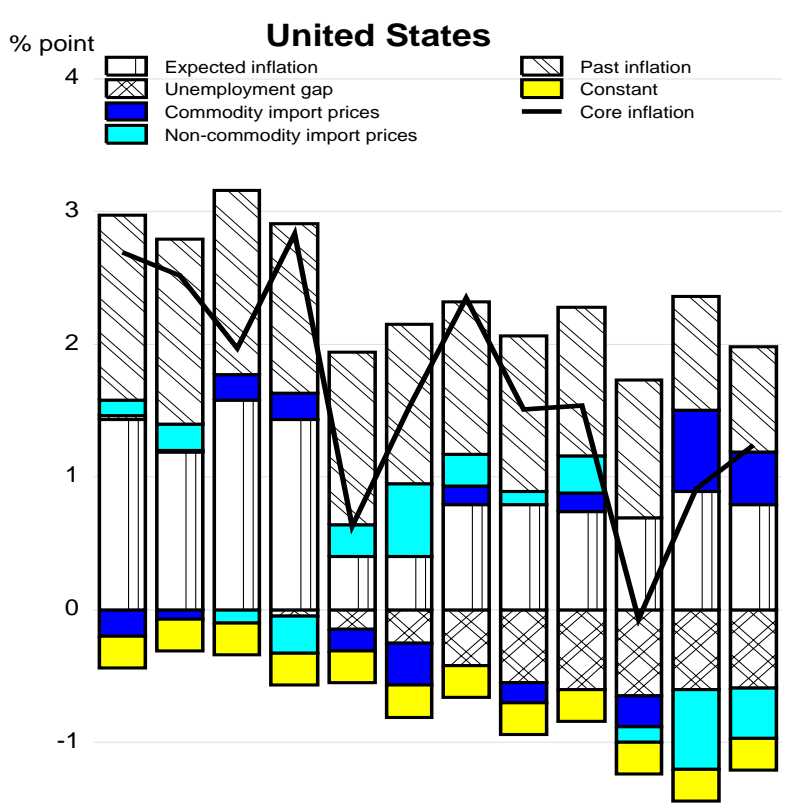

$$
-2
$$
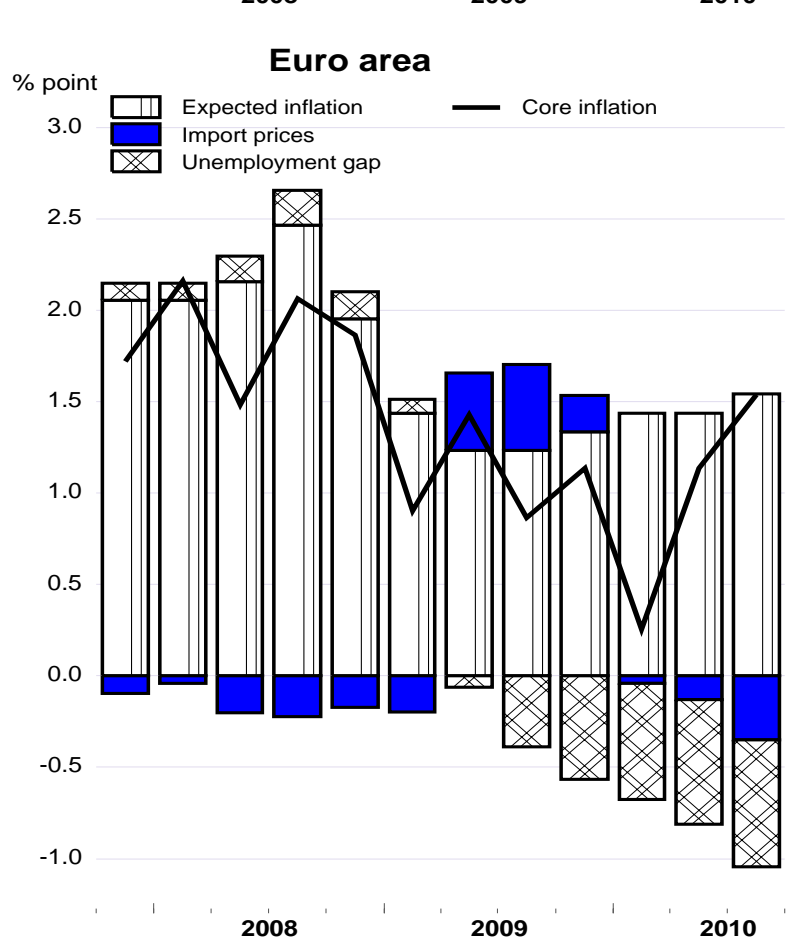

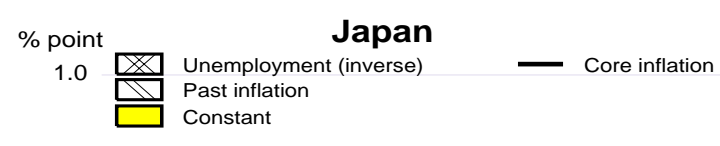

0.5
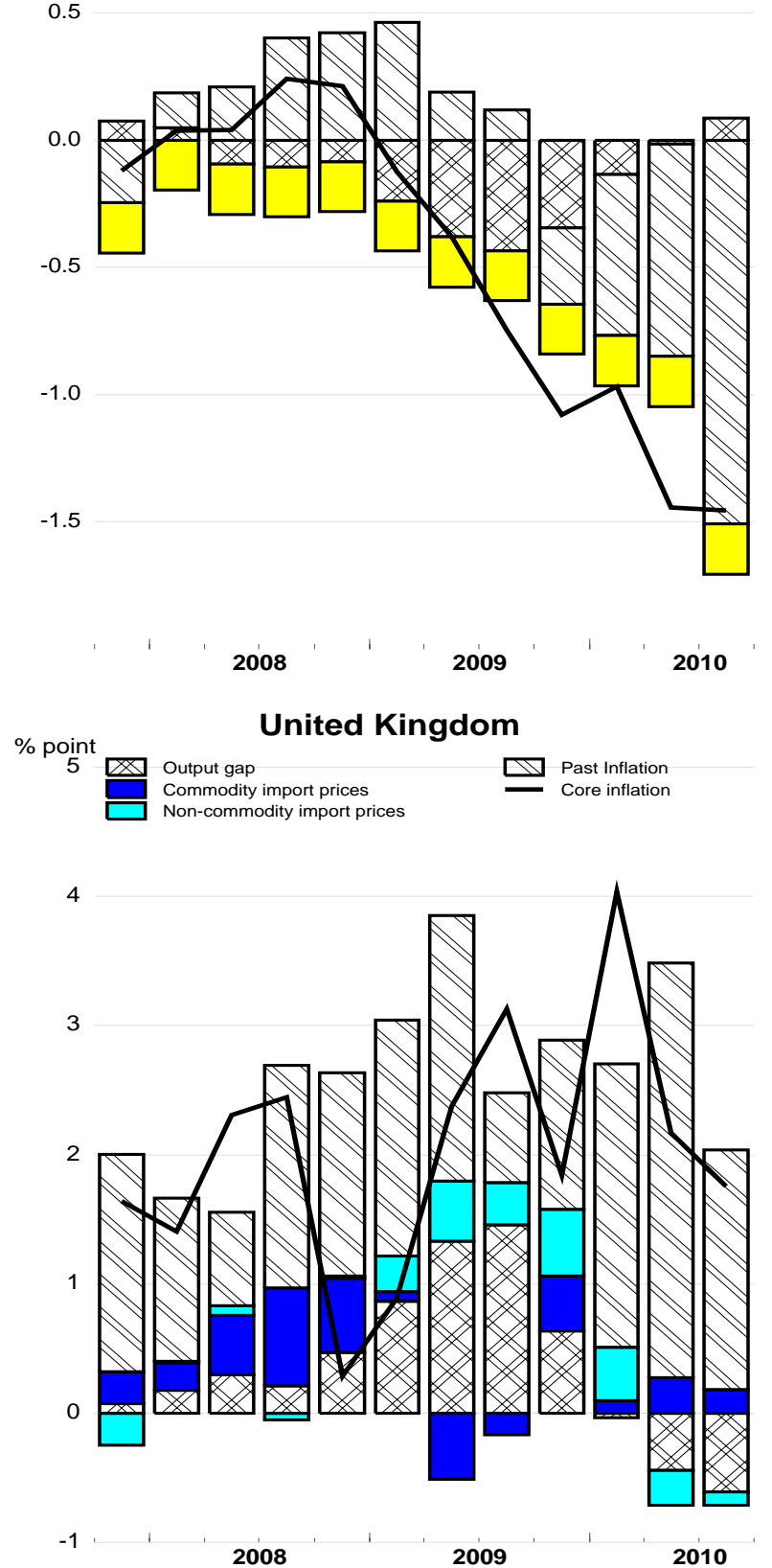

Note: For the euro area and the United States, the decomposition is based on the models that include the unemployment gap as a measure of economic activity. For Japan, it is based on the model including the inverse of the unemployment rate. For the United Kingdom, the model includes the output gap, because the unemployment gap was not significant in the econometric estimations.

Source: Authors' calculations. 


\section{The disinflation effect of economic slack in a low inflation environment: evidence from a cross-section of countries}

44. In a situation of very significant slack and low inflation, results obtained from analysis of more normal periods may not apply. Indeed, some specific factors not fully captured by Phillips curves estimated over long historical periods could hinder further disinflation. Nominal wage and price rigidities may become more binding when there is deflation or very low inflation, partly because many wage and pricesetters tend to resist outright nominal cuts. Empirically, Mourougane and Ibaragi (2004), Nishizaki and Watanabe (2000), and De Veirman (2009) show that low levels of inflation led to the flattening of the Japanese Phillips curve.

\section{Concept and Methodology}

45. Assessing if the disinflation effects of slack are moderated in a low inflation environment is difficult because the time series data of each country only include a very limited number of episodes with large and sustained economic slack that is comparable to the current one. Furthermore, low inflation has been seen only since the 1990s in most advanced countries. To work around these difficulties, this section reports a cross-sectional analysis focusing on inflation dynamics during episodes of persistent large slack. The methodology closely follows Meier (2010), who studies inflation dynamics during episodes in advanced economies since 1970 where at least eight consecutive quarters of negative output gaps exceed $1 \frac{1 / 2}{2}$ per cent in absolute terms. He finds that such episodes generally brought about significant falls in inflation rates but that disinflation tended to taper off at very low positive inflation rates. Using the same methodology, but focusing more on the relationship between the low inflation environment and the slope of the Phillips curve, this section tries to derive implications for the prediction of inflation.

46. The sample includes a total of 53 episodes, including 15 episodes for the 1970 s and 1980s, 15 episodes for the 1990s and pre-crisis 2000 s, and 23 episodes for the ongoing downturn. ${ }^{35}$ On average, an episode in the pre-crisis period lasts 14 quarters with an output gap of $-3.1 \%$. The OECD Economic Outlook No. 87 database is the source of output gap estimates and projections, the latter being used to identify ongoing episodes. ${ }^{36}$ The inflation indicator used for the analysis is core CPI inflation.

\section{Findings}

47. Figure 11 shows the median behaviour of core CPI inflation (measured as a 4-quarter backward moving average of quarterly annualised changes), during the episodes of large and persistent output gaps that occurred since the 1970, including those that are still ongoing. A trend of disinflation is observed for each time period, but with different characteristics. For the pre-1990 period, the inflation rate declined from somewhat above 8 per cent by around 2 percentage points between one quarter before and fours quarter after the start of the episode. For the post-1990 period but before the current crisis, the inflation rate declined from around $3 \frac{1}{2}$ per cent by 1.5 percentage point. The current ongoing episodes, where initial inflation was low, so far feature less than one percentage point disinflation. In sum, it appears that, when

35. Countries included in the episodes are the followings: Australia, Austria, Belgium, Canada, Switzerland, Denmark, Finland, France, Germany, Greece, Ireland, Italy, Japan, Luxemburg, Netherlands, New Zealand, Norway, Portugal, Slovakia, Spain, Sweden, United Kingdom, United States, and Western Germany. Some episodes, for which core CPI data are unavailable or which are of emerging countries, are excluded.

36. Although an episode of interest is defined as in Meier's (2010) work, which also uses OECD Economic Outlook data, the number of episodes and the number of periods of some episodes are different from his work, as he uses older data. 
initial inflation rates are lower, disinflation is weaker and ends earlier, although the current episodes are still ongoing and inflation rates in recent periods may have been sustained by tax hikes due to fiscal consolidation in some European countries.

Figure 11. Evolution of core CPI Inflation during episodes of persistent large output gaps

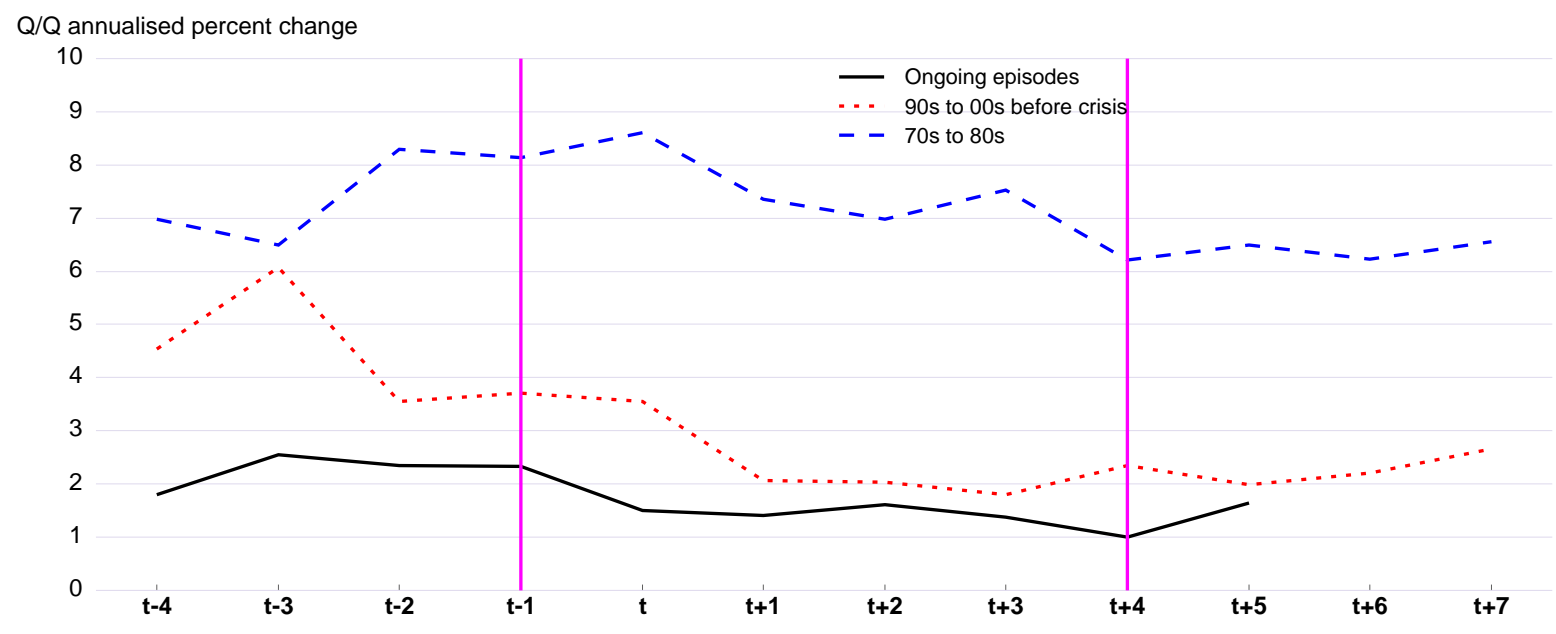

Note: An episode of persistent large output gap is a period where the output gap was below $-11 / 2$ per cent and lasted at least eight consecutive quarters. $t$ represents the quarter before the output gap falls below $-1 \frac{1}{2}$ per cent.

Source: Authors' calculations.

48. The effect of initial inflation rates on subsequent inflation during periods of persistent large output gaps becomes clearer when looking at individual episodes. Figure 12 relates inflation in the quarter before the start on an episode (i.e., the quarter before the output gap turns negative), to the average change in inflation during episodes (i.e., the change in inflation between the beginning and the end of an episode, divided by its length).The figure shows that lower initial inflation rates are associated with slower disinflation thereafter. This observation suggests that the extent of disinflation during the recent crisis might have been limited, because many countries entered into the crisis with low initial inflation rates.

49. Initial inflation rates may have such a strong link with the extent of disinflation through a changing sensitivity of inflation to economic slack, i.e. the slope of the Phillips curve may vary with the inflation rate. Data plotted in Figure 13 suggest that the relationship between average changes in inflation rates and average levels of output gap during the episodes was weaker in the 1990s and pre-crisis 2000s period than in the 1970s and 1980s period when inflation rates were generally higher.

50. The Phillips curve plotted on Figure 13 has a slope for the 1970s and 1980s, but becomes flat for the 1990s and 2000s. This observation suggests that a decline in trend inflation may have reduced the effect of economic slack on inflation even when economic slack is large and sustained. This conjecture motivates estimating the cross-sectional Phillips curve with a varying slope depending on the initial inflation rate. As shown in the equation reported on Figure 13, the estimated coefficient on the initial inflation rate is positive and significant at the $1 \%$ level and the fit is very good. ${ }^{37}$

37. One possible caveat to this analysis comes from the fact that the economic slack is difficult to measure and hence it is worth re-examining the relationship between the extent of disinflation and the economic slack with other measures of slack. From the viewpoint of economic forecast, a one-sided measure of the 
51. These results based on periods of persistent large output gaps and low inflation suggest that the risk of deflation may have been lower than what standard Phillips curves estimated over the full span of data may have suggested. However, there is too little data on episodes of large persistent economic slack and low inflation to draw a definitive quantitative inference that would pin down inflation forecasts taking into account the likely flattening of Phillips curves in such environments.

Figure 12. Extent of disinflation vs. initial inflation level in episodes of persistent large output gaps

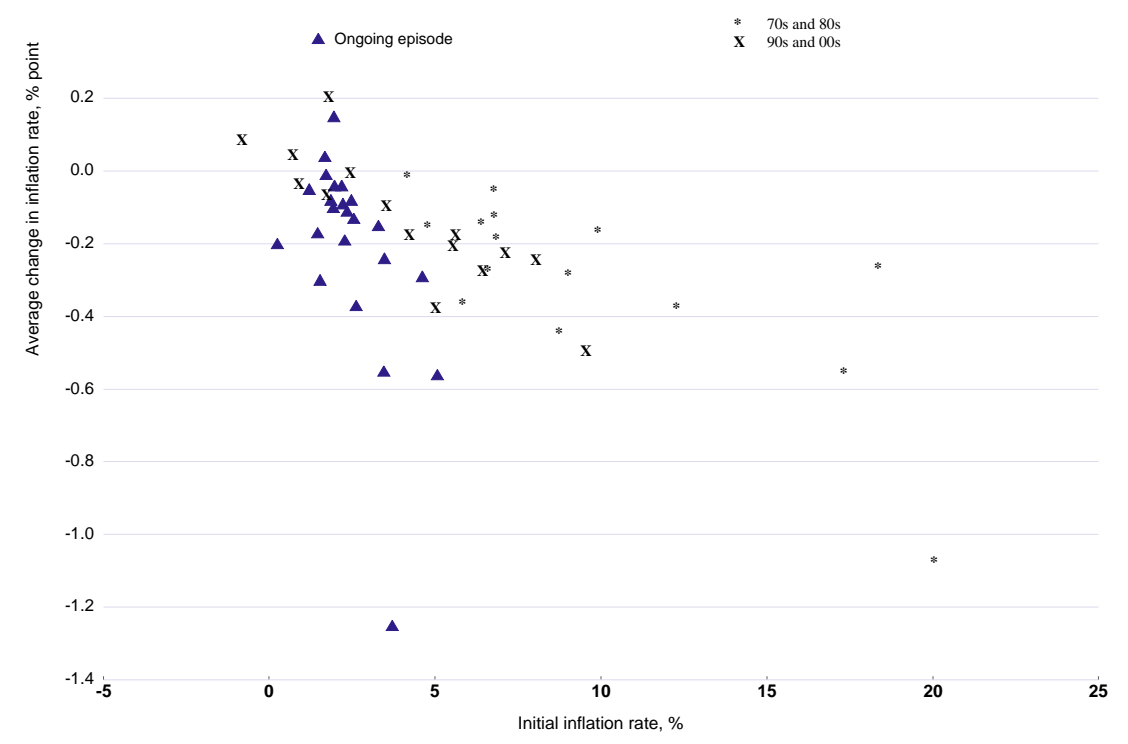

Source: Authors' calculations.

economic slack, which does not change with incoming data, is of interest and hence the Stock and Watson's (2010) unemployment recession gap has been employed as an alternative measure of slack. Results (not reported) show that the above findings are robust to this alternative measure: the slope of the Phillips curve significantly depends on the initial inflation rate and the low inflation environment has brought about a flat Phillips curve. 
ECO/WKP(2011)23

Figure 13. Extent of disinflation vs. average size of the output gap: the role of the initial inflation rate

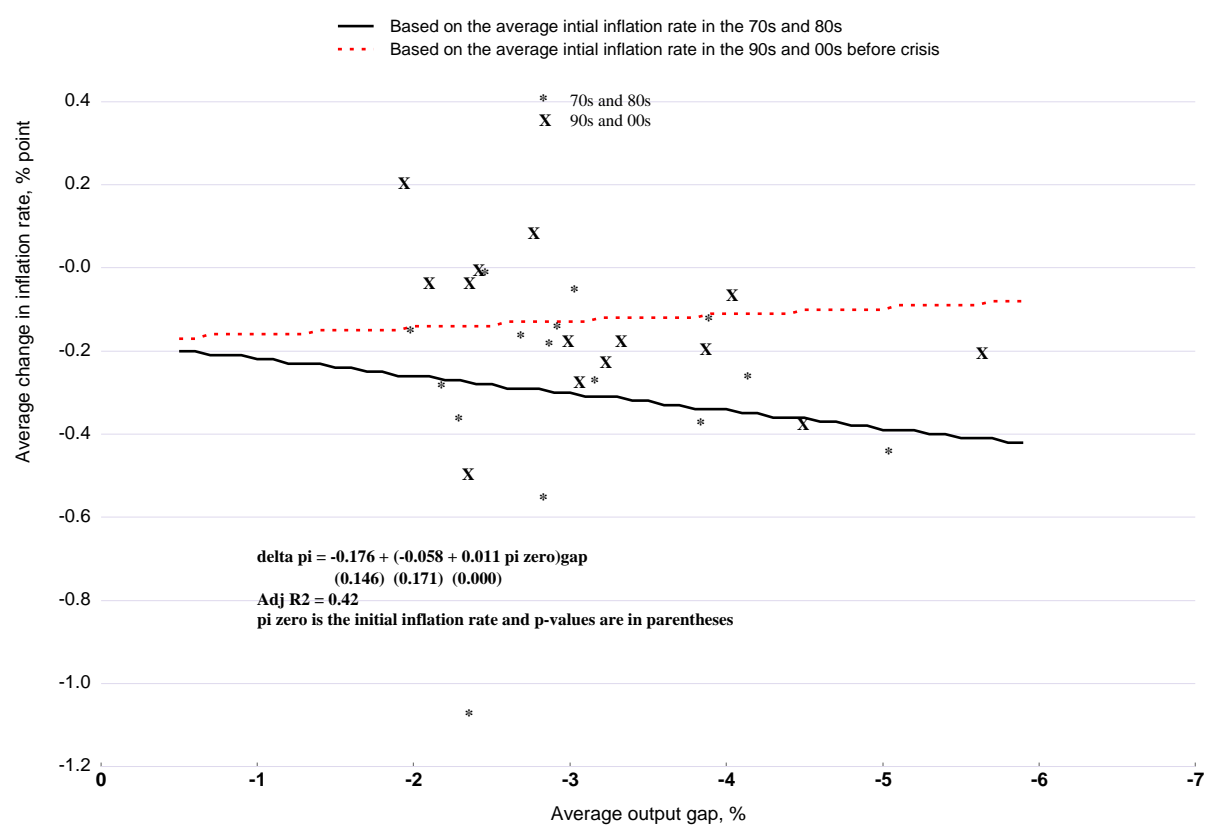

Source: Authors' calculations.

\section{Inflation expectations}

52. Since inflation developments depend to an important extent on inflation expectations, as shown by the Phillips curve analysis, the way the latter are determined is of key importance for price stability and for the conduct of monetary policy (Bernanke, 2010). Despite the fact that short- rather than long-term expectations enter the Phillips curves presented above, the focus in this section will be on long-run inflation expectations for two reasons. First, in principle, long-run inflation expectations should represent the underlying trend to which households and firms add their evaluation of the impact of temporary factors when forming their short-term expectations. Secondly, in practice, evidence shows that long-term inflation expectations are an important driver of short-term expectations (Hooper, 2010), with the latter exhibiting more volatility (Figures 14 and 15).

\section{Inflation expectations since the onset of the crisis}

53. In the United States, expectations for long-term inflation represented by three major indicators of long-term inflation expectations have exhibited little variation since the start of the crisis, which may reflect that expectations are well anchored. Professional forecasters surveyed by the Federal Reserve Bank of Philadelphia continue to expect an annual average rate of change for the consumer price index over the next 10 years of between 2 and $2 \frac{1}{2}$ per cent, although recent forecasts are below the middle of the range (Figure 14) ${ }^{38}$ Households' 5 to 10 -year-ahead expected inflation has also been stable. The Federal Reserve Bank of Cleveland's measure of long-term inflation expectations based on yield differences between nominal and indexed bonds has recently slipped back somewhat, but it may be influenced by shifting liquidity premia.

38. Data in the early period are from the Livingston survey, the Blue Chip, and the Hoey survey. See Levin and Taylor (2009) for the Hoey survey. 
54. Long-term inflation expectations also seem to be stable in the euro area and Japan (Figure 14). In the euro area, long-term HICP inflation expectations of professional forecasters surveyed by the European Central Bank and Consensus Economics have remained at around 1.9 or $2 \%$, consistent with the definition of price stability of the European Central Bank. In Japan, professional forecasters expect that 6 to 10 -yearahead CPI inflation rates will be around 1 per cent, consistent with the Bank of Japan's understanding of medium to long-term price stability, while break-even inflation rates have not returned to the pre-crisis level.

55. The dispersion of individual expectations may give information on the extent of risk about future inflation or deflation. In the United States, the disagreement among professional forecasters about the annual average inflation rate for consumer price index over the next 10 years increased after the start of the crisis and stayed high during 2009, mainly because forecasters with relatively low inflation expectations lowered their forecasts further (Figure 15). More recently, the dispersion of professional forecasts has narrowed, pointing to better anchored long-term inflation expectations. The dispersion of long-term inflation expectations among households has been relatively stable.

56. In the euro area, disagreement among professional forecasters on inflation 5-years-ahead increased in 2009 with a fall in the lowest quartile value and then the median expected inflation rate edged lower, as in the United States (Figure 15). Dispersion has contracted at the beginning of 2011, due to an increase in expected inflation by the lowest quartile. It is worth noting that the disagreement among professional forecasters in the euro area is generally smaller than in the Unites States, a fact which Beechey, Johannsen, and Levin (2008) and Kiley (2009) interpret as suggesting that long-run inflation expectations are better anchored in the euro area than in the United States reflecting the ECB's explicit long-run objective for inflation.

\section{Inflation expectations: potential drivers}

57. Whilst keeping in mind the specific features of the current situation, past experience can give indications about what can drive inflation expectations. Regression analysis has been conducted with a model similar to Trehan (2010):

$\Delta \pi_{t}^{e}=\kappa(L) \Delta \pi_{t-1}^{e}+v(L) z_{t}$

where $\Delta \pi_{t}^{e}$ is the first difference of long-term inflation expectations of professional forecasters or households and $z_{t}$ is a vector of variables including the first difference of the annualised inflation rate (core or headline CPI), the annualised rate of money growth, and the level of the output gap. ${ }^{39}$ Autoregressive terms enter with four lags for the United States and with one lag for the euro area. Also, current and four lags (United States) or one lag (euro area) of ${ }^{z_{t}}$ enter into the regression equation.

39. The differences from Trehan's (2010) approach are the focus on long rather than short-term expectations, the introduction of autoregressive terms, the first differencing of inflation expectations, and the use of not only the CPI inflation rate but also the output gap and money growth as explanatory variables. Autoregressive terms are introduced to avoid omitted-variable bias as they are sometimes found to be significant. The first differencing allows for the possibility of permanent shifts in long-term inflation expectations as suggested by the concept of non-accelerating inflation rate of unemployment. Finally, the output gap is used as an alternative explanatory variable in order to directly study how the current situation of persistent economic slack affects inflation expectations. 
Figure 14. Long-term inflation expectations in the United States, the euro area and Japan

\section{United States}

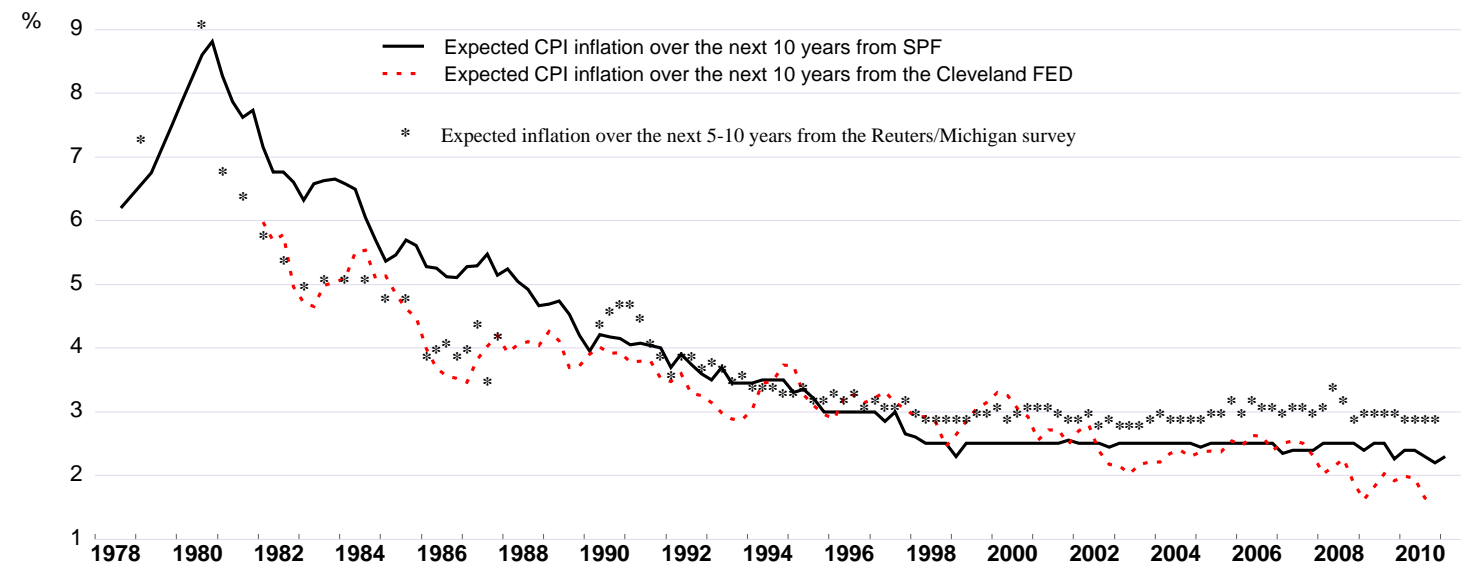

Euro area

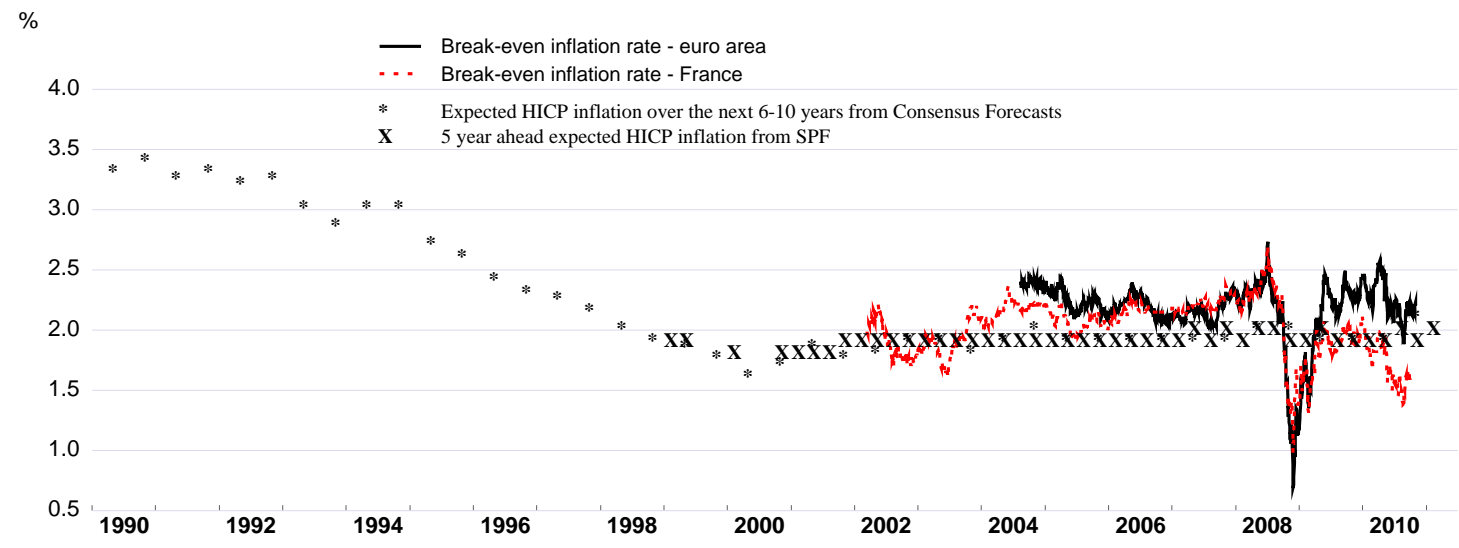

Japan

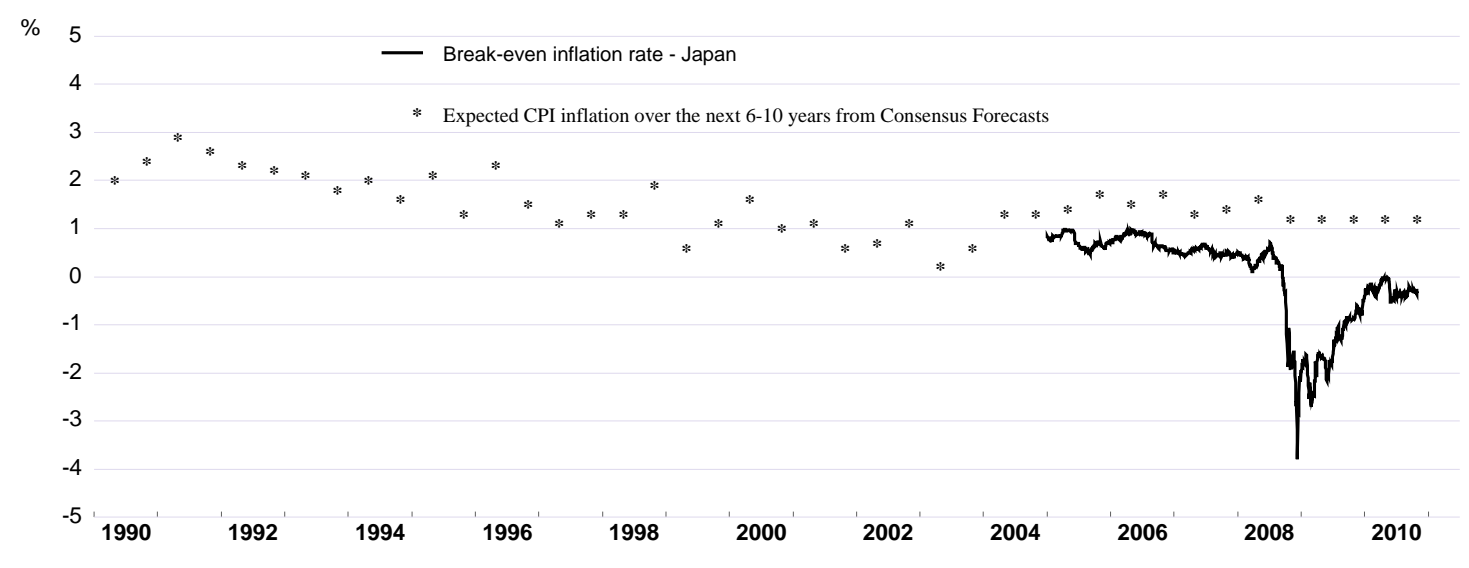

Source: Authors' calculations. 
Figure 15. Risk surrounding long-term inflation expectations in the United States and the euro area United States - Survey of Professional Forecasters

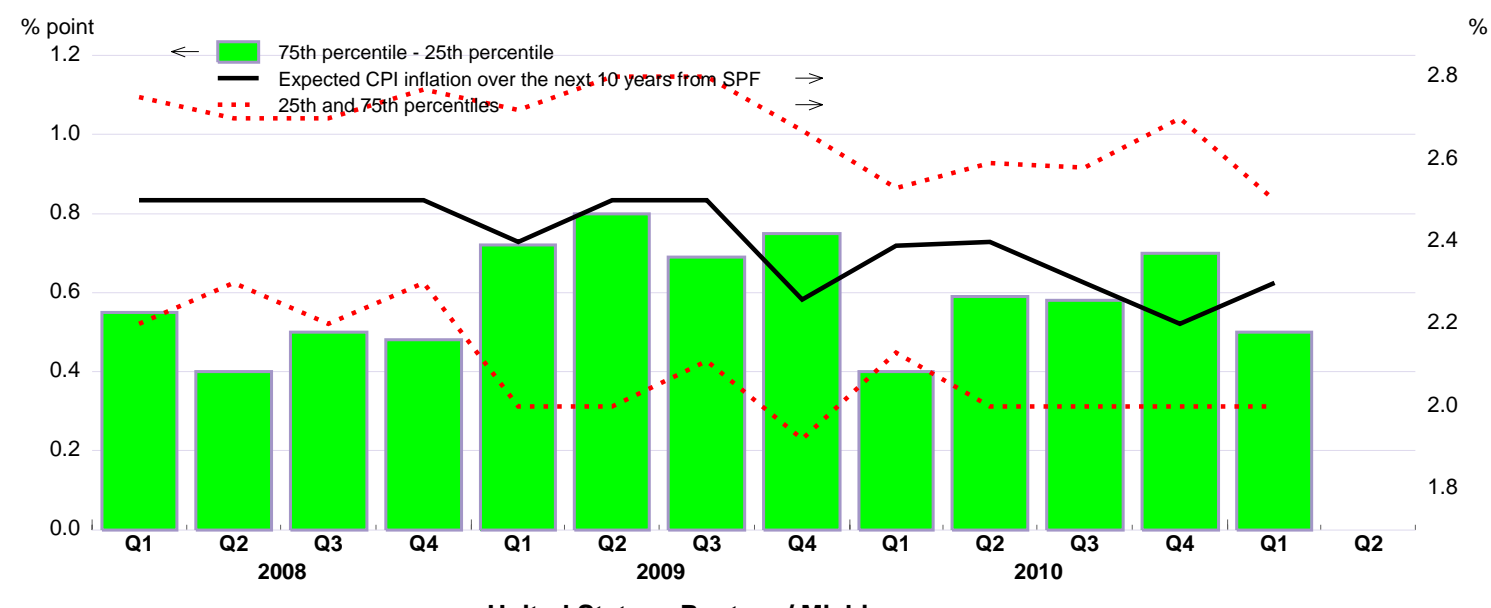

United States - Reuters / Michigan survey

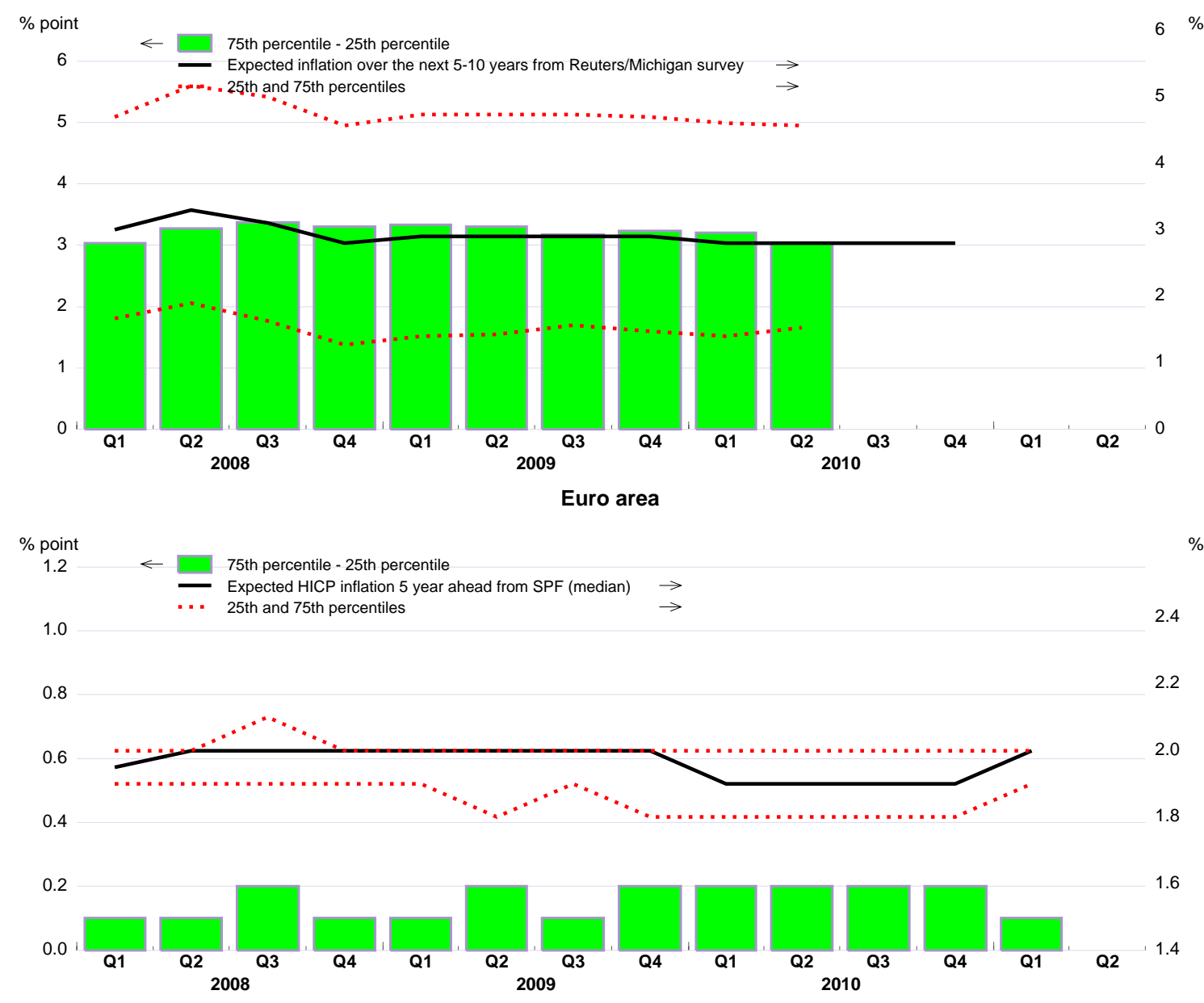

Source: Authors' calculations. 
Figure 16. Short-term inflation expectations in the United States and in the euro area

\section{United States}

$\% 12$

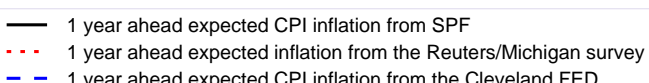

- - 1 year ahead expected CPI inflation from the Cleveland FED

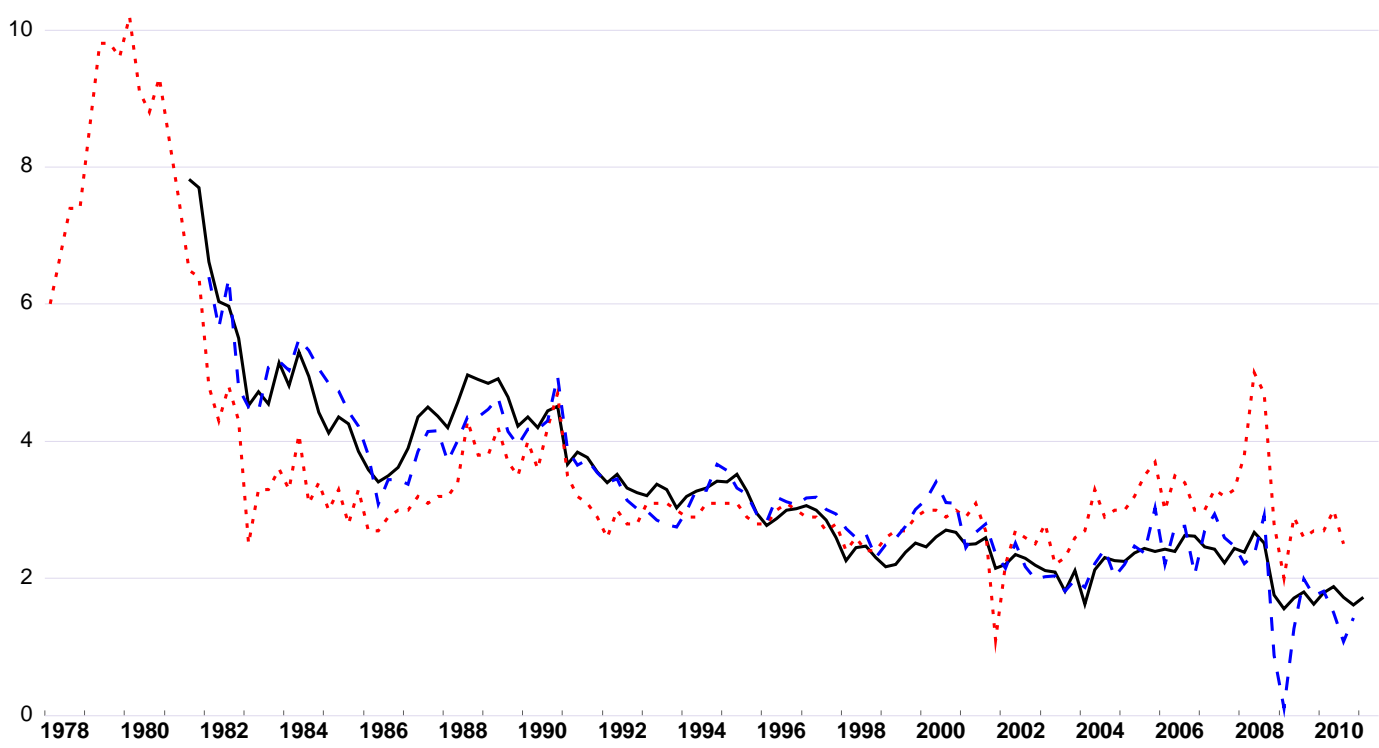

Euro area

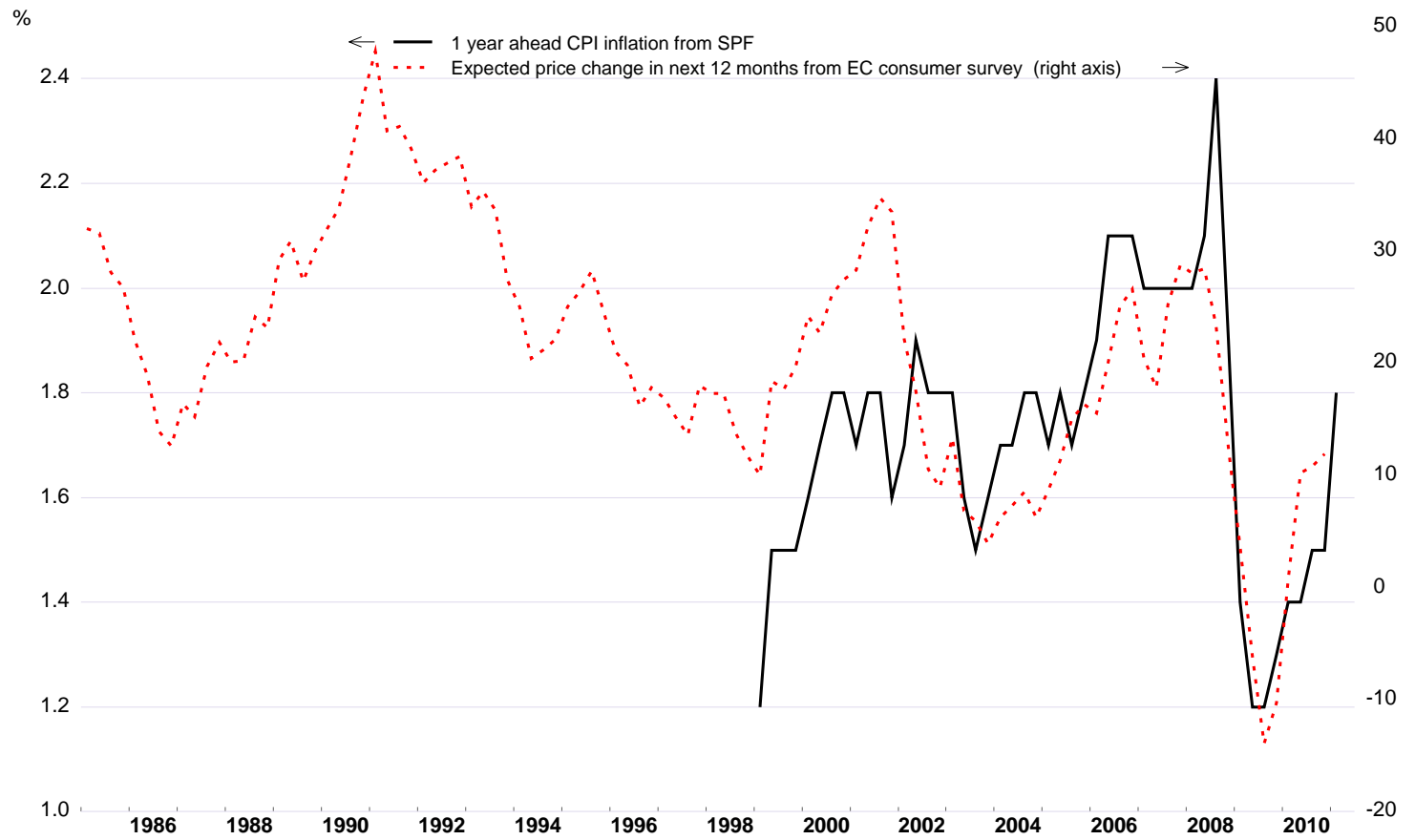

Note: The European Commission (EC) consumer survey reports inflation expectations in the form of a balance (weighted average) of six qualitative answers. Balance values range from -100 (all respondents think inflation will decelerate) to +100 (all respondents think inflation will accelerate).

Source: Authors' calculations. 
58. Data for the United States are quarterly, while data for the euro area are semi-annual because long-term inflation expectations are taken from Consensus Economics, which has published long-term forecasts only on a semi-annual basis for a relatively long period (since 1990). The timing of the inflation rate and output gap data is consistent with that of inflation expectations formation. US inflation expectations of professional forecasters are published by the Federal Reserve Bank of Philadelphia in February, May, August, and November and the survey is conducted around the beginning of each month. Hence, when the Philadelphia Fed's measure of inflation expectations is used, the data point for the previous quarter is used as determinant of current inflation expectations. On the other hand, such adjustment is not implemented when inflation expectations are measured by the Reuter/University of Michigan's household survey data, which are published on monthly basis. With regard to the euro area, current inflation expectations are the October-March average for the April forecast and the AprilSeptember average for the October forecast.

59. Figure 17 shows the evolution of the long-run elasticity of long-term expected inflation to the inflation rate and the output gap, estimated using a 15 -year rolling window. ${ }^{40}$ When estimated using recent samples, the effect of changes in inflation rates or the output gap on long-run inflation expectations are almost zero or statistically insignificant, except for the effect of the core inflation rate on US households' expected inflation. Even in the case of US households' expected inflation, the elasticity is only 0.08 . In this country, the effect of the output gap on long-run inflation expectations has been almost nil since the 1990s. The estimated response of long-run inflation expectations to changes in money growth is statistically insignificant or has the wrong sign both in the United States and the euro area (results not reported). That long-term inflation expectations are less responsive than in the past to current macroeconomic outcomes may so far be attributed to enhanced central bank credibility.

\section{Future inflation expectations}

60. If taken at face value, these results coupled with the Phillips curve estimates reported above would suggest that inflation expectations might increase somewhat over the forecast period in response to the recent pick up in headline inflation. However, the impact is expected to be small, with little knock-on effect on inflation outcomes. ${ }^{41}$

40. In other words, the picture shows the long-term reaction of inflation expectations to a unit shock to its determinants for models estimated over a moving sample of 15 years. For example, the value for the fourth quarter of 2004 represents the impact (elasticity) of a unit shock to the inflation rate and the output gap on inflation expectations 25 years in the future, for a model estimated over the period 1990Q1-2004Q4.

41. Not too much comfort should be taken from this observation because firms and households could change the way in which they form their expectations. For example, Galati et al. (2010) find signs of the expectation-formation mechanism being fragile in high-frequency bond-market data, where implied anticipated inflation appears to have become more sensitive to economic news since the crisis intensified in the third quarter of 2008 . 
ECO/WKP(2011)23

Figure 17. Long-run elasticity of long-term inflation expectations

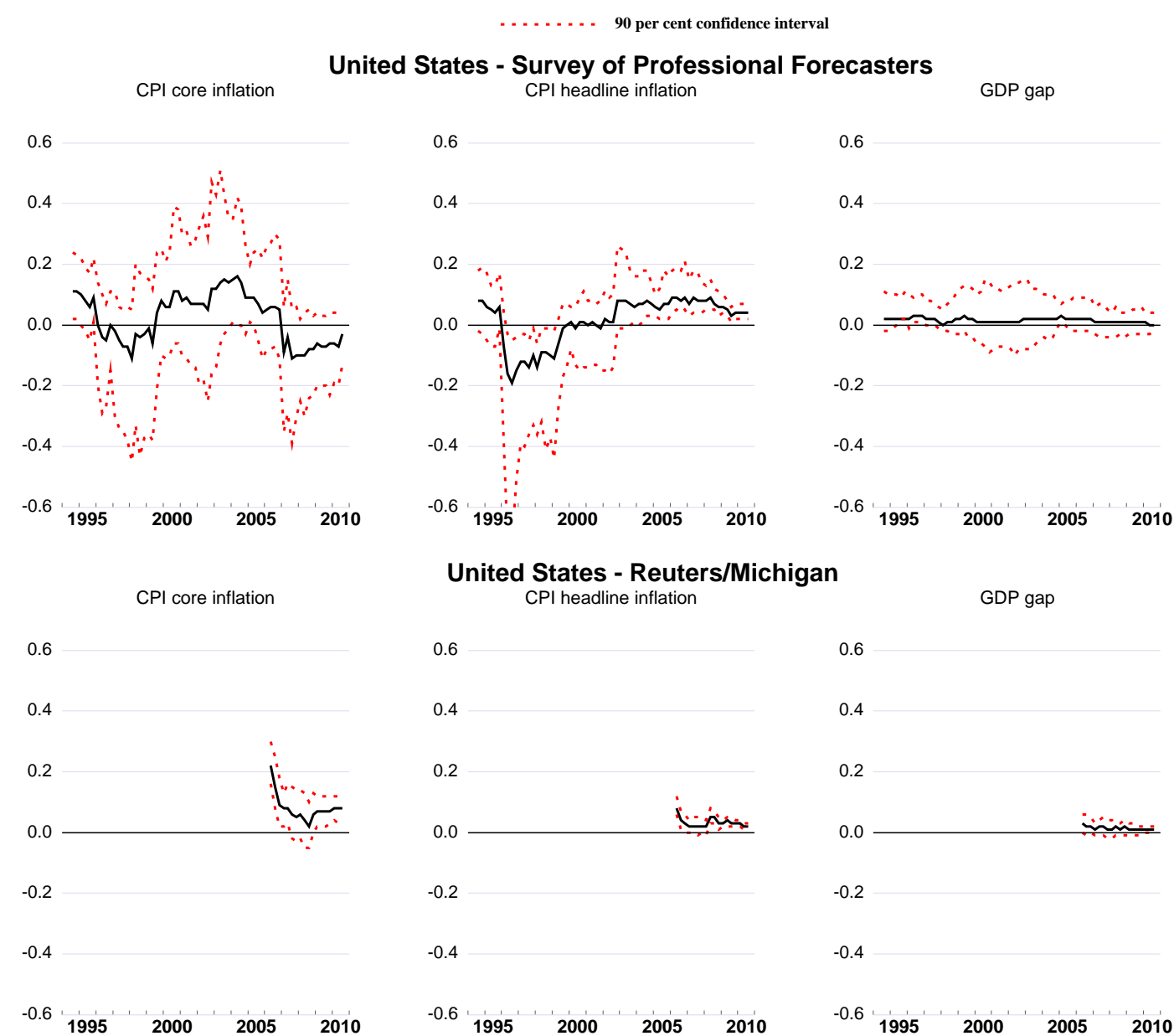

Euro area - Survey of Professional Forecasters

CPI core inflation

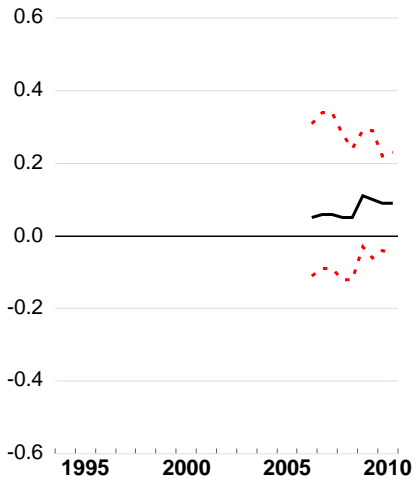

CPI headline inflation

0.6

0.4

0.2

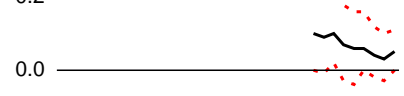

$-0.2$

$-0.4$

$-0.61995 \quad 2000 \quad 2005 \quad 2010$
GDP gap

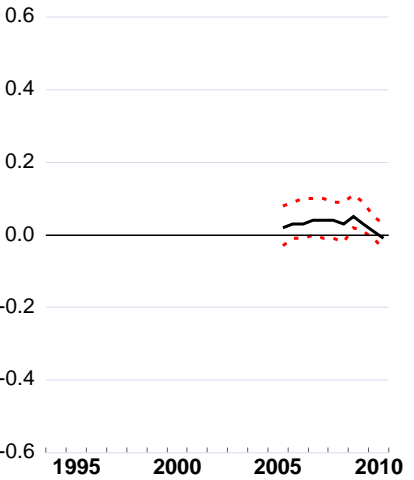

Note: Dotted lines show $90 \%$ confidence intervals computed using a bootstrap Monte Carlo procedure with 1000 replications. The long-run elasticity is measured by the accumulated change in long-term inflation expectations over 25 years after a one percentage point change in inflation and the output gap.

Source: Authors' calculations. 
61. In the somewhat longer term, the evolution of inflation expectations might also be tilted to the upside. This is because central banks in several advanced countries have implemented large-scale asset purchase programmes and the public may lose trust in central banks' commitment to maintain price stability. Especially, if the public were to consider that central banks' monetary policy actions are constrained by a need to keep longer-term interest rates low due to increased fiscal risks, inflation expectations might start to rise. However, this risk did not materialise during the first round of quantitative easing: Guidolin and Neely (2010) found that the 2008-2009 FOMC announcements of large-scale asset purchases had only very small effects on break-even inflation expectations. The second round of quantitative easing seems to have had a larger effect as break-even inflation expectations have risen by some 70 basis points since the FOMC announcement, although its impact is difficult to disentangle from other factors such as a series of positive economic news, the decision to extend tax cuts that were set to expire, and the recent substantial increase in commodity prices. ${ }^{42}$ In the medium-term, most advanced countries have fiscal consolidation plans that have bolstered market confidence in fiscal sustainability and hence the inflationary risk should remain small as long as consolidation plans remain credible. On the opposite side, there is also a risk that fiscal policy might reinforce disinflation over the coming years, if the scale of consolidation is more than expected.

\section{The outlook for inflation, risks and policy challenges}

\section{Prospects for inflation}

62. Annual measures of inflation have trended down in major OECD economies during the economic crisis, but seem now to be rebounding on the back of the substantial appreciation in commodity prices and indirect tax increases in some countries. Nevertheless, core inflation measures still remain below explicit or implicit target rates, except in the case of the United Kingdom. In a context of still relatively tight credit conditions, deleveraging in the private sector, and in light of substantial fiscal consolidation needs going forward that will serve as a drag on economic activity, concerns arise that inflation will remain low. To assess the inflation outlook and associated risks, a forecasting exercise has been performed based on the Phillips curve models presented in Section 2 and the November 2010 projection of explanatory variables (output gap, unemployment, and non-commodity prices) presented in the OECD Economic Outlook No. 88. The analysis concentrates on a two-year forecast horizon, which is relevant from the point of view of monetary policy. The exercise, which uses data until mid 2010, assumes constant inflation expectations and commodity prices in the future.

63. Results of this forecasting exercise point to inflation remaining low but positive in the near term but with a low probability of deflation. In particular, the outlook for inflation in each of the four economies under consideration until the end of 2012, conditional on the November 2010 forecast for explanatory variables and excluding the recent period of increasing commodity prices, is as follows (Table 4 and Figure 18):

- In the United States, core CPI inflation is projected to remain broadly stable with an extremely low probability of hitting deflation at the end of 2012.Core inflation will rise faster than projected here if economic slack contracts more rapidly than assumed in the Economic Outlook No. 88 on account of larger-than-expected federal government spending and tax cuts announced in December 2010.

42. In the period since the FOMC announcement, long-term real yields have risen by about 80 , suggesting that the increase in long-term rates over the period was part of a broad upward reassessment of economic prospects beyond the move in inflation expectations. 
- In Japan, which has been in deflation for about a decade, the pick-up in economic activity is expected to mitigate deflation slightly going forward. The annual core deflation rate is expected to drop only by some 0.2 percentage points between now and the end of 2012. Nevertheless, the projections here may overestimate deflation in core prices as the recent drift down in core inflation was mainly due to the introduction of government support for high school tuition fees (see above). Moreover, the hike in the tobacco tax rate in the fourth quarter of 2010 will certainly contribute to reduce the pace of annual deflation, especially until the third quarter of 2011.In the United Kingdom, where inflation has been higher than in the other economies, core inflation is expected to decelerate by about 1.6 percentage points from its value in the third quarter of 2010 . The projected core inflation rate at the end of the forecast horizon, implies a relatively high probability of deflation (25\%), which should be seen in the context of the relatively poor performance of the model and the associated wide confidence intervals. On the other hand, the projection here may underestimate core inflation because the projected VAT increase in January 2011 will show up in higher core CPI growth in the course of 2011.

- In the euro area, core inflation is also expected to remain low but increasing smoothly towards the end of the projection period. Annual core inflation is expected to increase by some 0.12 percentage points, from a low of about $1 \%$ currently, and the probability of deflation in core prices at the end of the forecast period in the euro area is zero.

Table 3. Outlook for inflation in major OECD economies

\begin{tabular}{|c|c|c|c|c|}
\hline \multicolumn{4}{|c|}{ Annual inflation } & \multirow{2}{*}{$\begin{array}{c}\text { Probability of } \\
\text { deflation at } 2012 \mathrm{Q} 4\end{array}$} \\
\hline & 2010Q3 & 2012Q4 & Difference & \\
\hline \multicolumn{5}{|l|}{ United States } \\
\hline Core CPI & 0.9 & 0.9 & -0.0 & $3 \%$ \\
\hline Core PCE & 1.3 & 0.5 & -0.8 & $21 \%$ \\
\hline \multicolumn{5}{|l|}{ Japan } \\
\hline Core CPI & -1.5 & -1.2 & 0.2 & $98 \%$ \\
\hline \multicolumn{5}{|c|}{ United Kingdom } \\
\hline Core CPI & 2.5 & 0.9 & -1.6 & $25 \%$ \\
\hline \multicolumn{5}{|l|}{ Euro area } \\
\hline Core CPI & 1.0 & 1.1 & 0.1 & $0 \%$ \\
\hline
\end{tabular}

Note: Annual inflation and probability of deflation in the fourth quarter of 2012 are the averages across models. Probability of deflation refers to the probability of annualised quarterly inflation being below zero at the end of 2012 .

Source: Authors' calculations. 
Figure 18. Projections for core CPI inflation based on the Phillips curve models
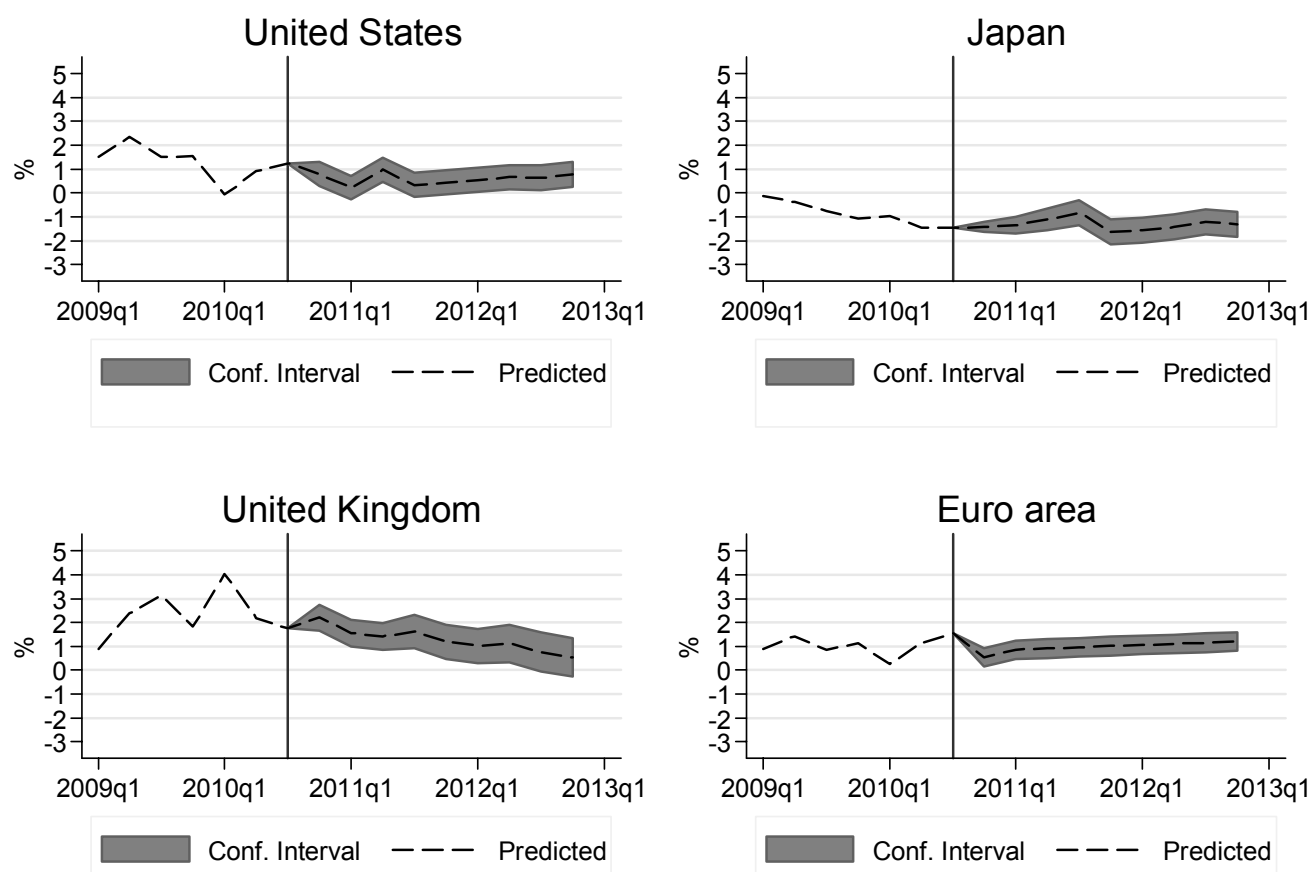

Note: Projections for the explanatory variables are those in the Economic Outlook No. 88 and assume constant inflation expectations at their latest observed value (1.6\% in the United States and 1.5\% in the euro area in the fourth quarter of 2010$)$. For the euro area and the United States, the prediction is based on the models that include the unemployment gap as a measure of economic activity. For Japan, it is based on the model including the inverse of the unemployment rate. For the United Kingdom, the model includes the output gap, because the unemployment gap was not significant in the econometric estimations. Grey areas represent $70 \%$ confidence intervals, based on a normal distribution.

Source: Authors' calculations.

\section{Risks}

64. Uncertainties regarding the inflation outlook presented before are still high, but have been tilted to the upside recently. A number of factors that may exert downside pressure on inflation over the forecast horizon are the following:

- A more subdued growth path than envisaged in these projections would hold inflation near recent low levels, raising the risk of deflation if a negative shock hits these economies.

- Inflation expectations may drift down if they become again more sensitive to economic outcomes and a negative shock hits these economies. This would put downward pressure on inflation and raise the probability of deflation. For example, assuming a decrease of 0.5 percentage points in inflation expectations between the third quarter of 2010 and the end of 2012 in the United States would increase the probability of core CPI deflation from $3 \%$ to about $21 \%$ at the end of the forecast period. For the euro area, the increase in the probability of deflation would still be very small (3\% compared to $0 \%$ in the baseline, see Figure 19$)$.

- Because rents tend to lag house prices, persistent weaknesses in housing markets could put further downward pressure on core inflation. The impact can be expected to be greater in the United States, due to the higher share of housing costs in the core index, and where house prices 
have started to contract again since the middle of 2010. In Japan, where the weight of housing costs in the core index is also high, intensified weakness in housing markets would add to deflationary pressures. In contrast, a smaller impact can be anticipated in the euro area and the United Kingdom, though there are signs of renewed weaknesses in the UK housing prices.

65. However, other factors may work in the direction of pushing up inflation relative to the projections presented above:

- The findings for a cross-section of countries that have experienced episodes of persistent large output gaps suggest that price changes tend to become less responsive to resource slack in the low inflation environment.

- Another issue that clouds the assessment of the inflation-output relationship via the Phillips curve is that output gaps are difficult to measure, especially at present due to the uncertainty of the impact of the crisis on potential output. For instance, if the current downturn has involved a stronger decline in supply potential than estimated in the OECD Economic Outlook No. 88 (of around $3 \%$ on average in the OECD area), the output gap will be smaller going forward and disinflationary pressures weaker. ${ }^{43}$ If for instance, in the United States the output gap was one percentage point narrower than projected in the OECD Economic Outlook No. 88, inflation would be some 0.13 percentage points higher at the end of the forecast horizon (Figure 20).

- Inflation might also be more resistant to economic slack if there are large increases in non-labour input costs, for example because of higher commodity prices or because of a depreciating currency. If the recent upswings in commodity prices are leading manifestations of global inflationary pressures, because of faster economic growth in emerging economies or spillovers from easy monetary policy in OECD countries, then inflation outcomes may turn out to be higher than projected here, as mentioned before.

- Another element that can push inflation above the projections presented above is if the fiscal consolidation efforts, which are reflected in output gap projections, include increases in indirect taxes.

- Inflation expectations can quickly put upward pressure on inflation if they start to increase (Figure 19). For instance, hypothetically, if the public started to be concerned about central banks' operational independence, as de facto they have become increasingly involved in public debt management in a context of very strained fiscal positions, fears of debt monetisation could prompt higher inflation expectations. Similarly, the massive expansion in central banks' balance sheets and the surge in base money could be seen, whether warranted or not, as creating a risk of broader monetary and credit growth, with eventual effects on inflation in the long term. The sharp increase over the past two years in the prices of gold and silver, two metals with multi-millennial track records as stores of value, suggests that some investors might be purchasing them as a long-term inflation hedge.

43. For example, very large increases in unemployment and the downsizing of some sectors may lead to an upward shift in the level of structural unemployment. 


\section{Policy implications}

66. Policy priorities are different in the short-to-medium term and in the long run. The previous findings regarding the tame inflation outlook in major OECD economies until the end of 2012 would call for a gradual normalisation of the monetary policy stance over this horizon. Authorities should nevertheless closely monitor the potential build up of broad-based inflationary pressures over the medium term coming from strong commodity prices, advancing and accelerating the pace of policy normalisation if necessary.

67. In the longer term, central banks must ensure that their unconventional measures do not put their hard-won credibility at risk. In particular, as mentioned above, the massive expansion in central bank liquidity could also be perceived as creating an inflation risk in the long term, above and beyond that implied by strong commodity prices, especially if quantitative easing were to be seen by some as a way of funding governments. It is particularly important that central banks communicate clearly how they intend to withdraw liquidity when the need arises and about their determination to tighten policy as required from the point of view of their own objectives, independently of the fiscal situation. ${ }^{44}$

Figure 19. Core inflation in the euro area and the United States under different scenarios for inflation expectations

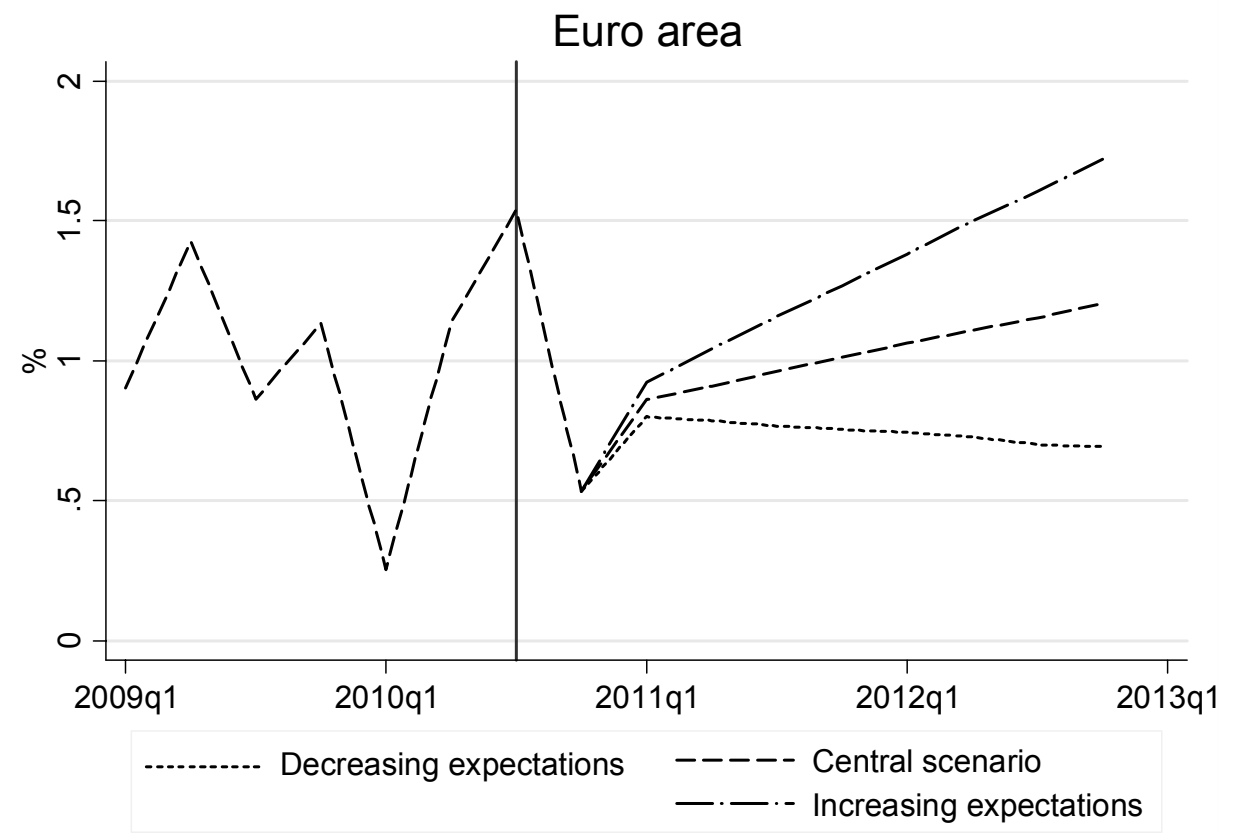

44. See for instance Minegishi and Cournède (2010) for a discussion of the various ways of withdrawing or sterilising central bank liquidity. 
ECO/WKP(2011)23

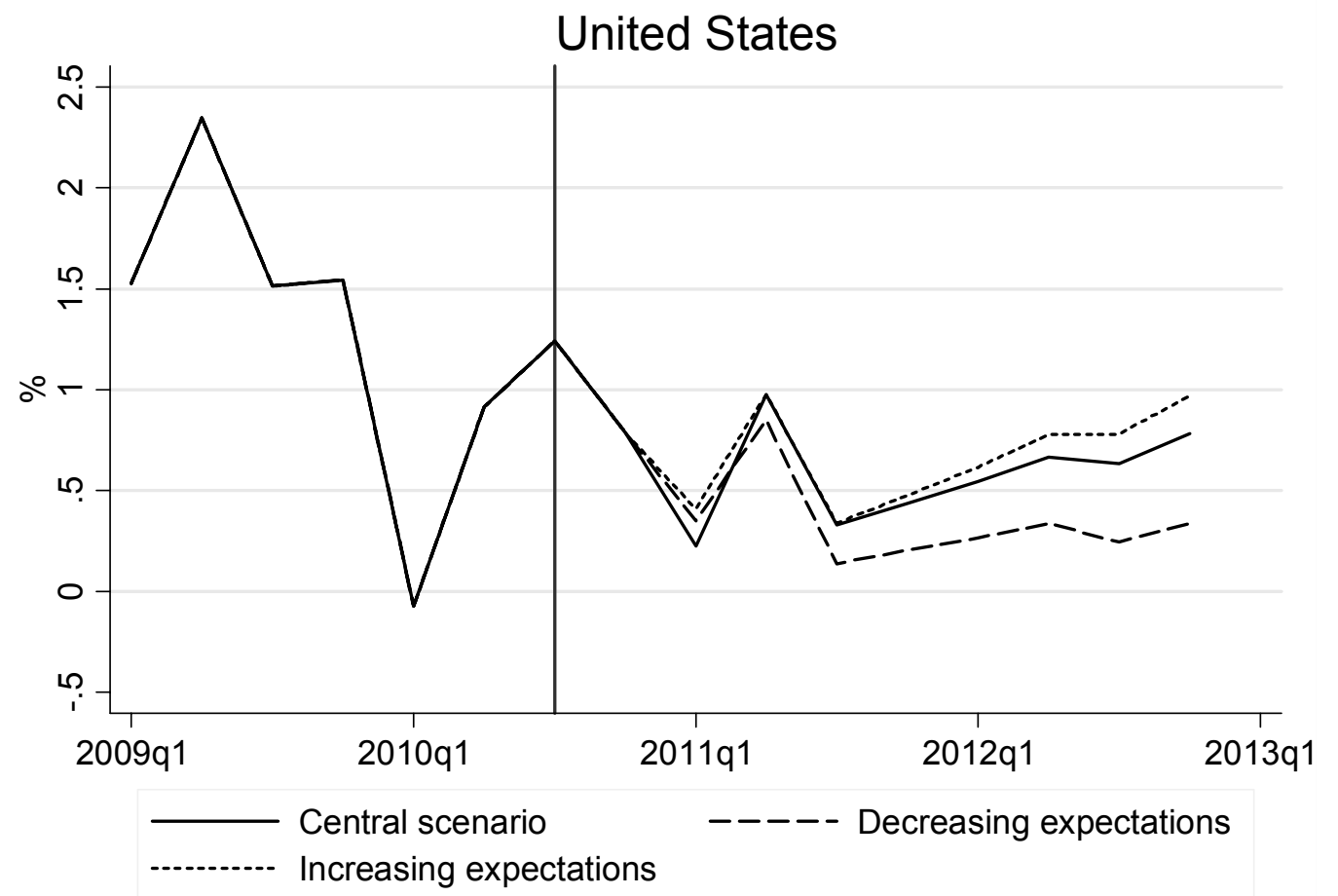


Note: Projections are based on the unemployment gap models for core CPI inflation in the United States and the euro area. The central scenario is based on the projection of explanatory variables in the Economic Outlook No. 88 and assumes constant inflation expectations at their latest observed value (1.6\% in the United States and $1.5 \%$ in the euro area in the fourth quarter of 2010$)$. The decreasing inflation expectations scenario refers to a smooth 0.5 percentage point reduction in expected inflation between the fourth quarter of 2010 and the end of 2012. The increasing inflation expectations scenario refers to a smooth convergence to expected inflation levels which are 0.5 percentage point higher than in the fourth quarter of 2010.

Source: Authors' calculations.

Figure 20. Core inflation in the United States under a narrower output gap

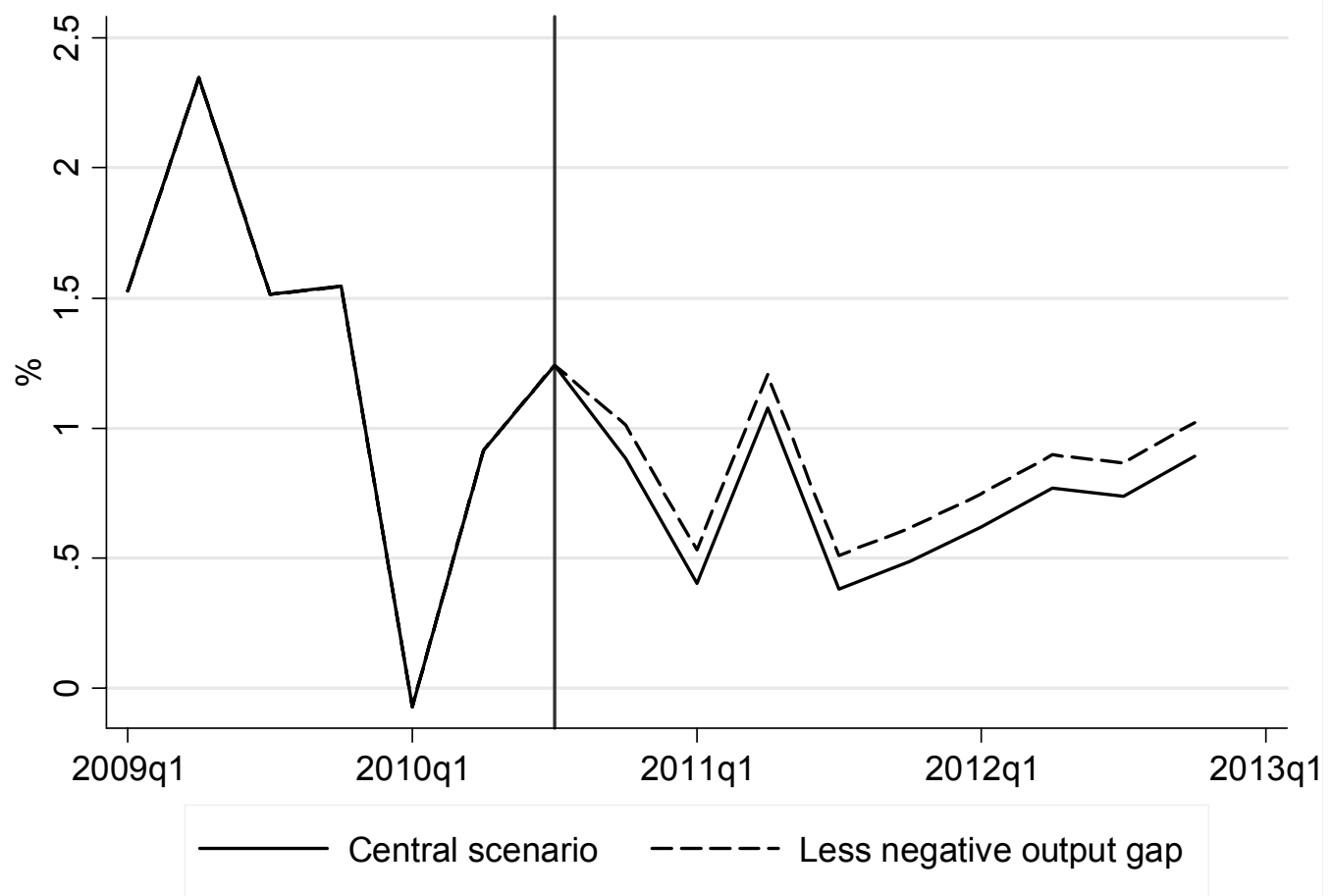

Note: The central scenario is based on the projection of the output gap in the Economic Outlook No. 88 and assumes constant inflation expectations at their latest observed value $1.6 \%$ in the United States and $1.5 \%$ in the euro area in the fourth quarter of 2010). The less negative output gap scenario assumes that the output gap is one percentage point narrower than in the Economic Outlook No. 88. Projections are based on the model for core CPI inflation that includes the output gap as a measure of economic activity.

Source: Authors' calculations. 
ECO/WKP(2011)23

\section{ANNEX 1 \\ THE DETERMINANTS OF HEADLINE INFLATION IN MAJOR OECD ECONOMIES}

\section{Estimation of Phillips curves for headline inflation in major OECD economies}

68. Headline inflation rates have traditionally been far more volatile, due to commodity price swings. Over the past few years, the surge and subsequent decline of global commodity prices, particularly food and energy, was a driving factor behind the sharp rise and fall of headline inflation. More recently, strong commodity prices have contributed to push up annual headline inflation rates both within and outside the OECD area. This Annex aims at disentangling the main determinants of headline inflation in the four countries under consideration based on a Phillips curve analysis akin to that used in the main text and using data until mid 2010.

\section{Data and sample period}

69. The measures of inflation retained in the analysis are as follows. For the United States: headline CPI all items (CPI) and headline personal consumption expenditure deflator (PCE) ${ }^{45}$ In the case of the euro area and the United Kingdom, the focus is on the headline harmonised index of consumer prices (HICP) ${ }^{46}$ For Japan, the consumer price index (CPI) is used. The same set of explanatory variables for core inflation is included in the regressions for headline inflation. More details regarding the data used in the empirical analysis can be found in Table A1.1.

70. In the United States and the United Kingdom, models are estimated starting in the third quarter of 1982 and since the first quarter of 1981, respectively, when consumer inflation became less persistent in these countries (Halunga et al., 2009). In the case of Japan, the focus is on the same sample period as in the United States. Finally, in the euro area, the estimations start in the first quarter of 1999, when data on quantitative measures of expected inflation started to be gathered by the European Central Bank. The sample ends in the third quarter of 2010 in the United States, and in the second quarter of 2010 in the remaining countries.

\section{Estimation results}

71. Estimation results are presented in Tables A1.2 to A1.6. The econometric specification for headline inflation in the euro area, the United Kingdom and the United States is given by equation (1) in the main text, while that for Japan is given by equation (2). The overall historical performance of the models seems to be quite satisfactory for headline inflation measures in the United States and Japan (Figures A1.1 to A1.3). The performance of the models seems less satisfactory in the United Kingdom (Figures A1.4), while the historical fit of the model for headline inflation in the euro area seems relatively adequate (Figure A1.5).

45. This study does not focus on the GDP deflator because its evolution is very close to the PCE deflator.

46. Previous work for the United Kingdom has also focused on the RPIX because this was the price index targeted by the monetary authorities until December 2003 (Kara and Nelson, 2002). 


\section{Decomposing the contribution of explanatory variables to headline inflation outcomes}

72. In order to disentangle the main drivers of headline inflation, the contribution of explanatory variables on each measure of inflation is decomposed since the beginning of the recession in the last quarter of 2007, and up to the third quarter of 2010 (Figures A1.6 to A1.10). The main results of this exercise are as follows:

- The main drivers of headline inflation measures in the United States are commodity import prices and expected inflation (Figures A1.6 and A1.7). Economic activity was a relatively minor contributor until well into 2008, when wide resource slack in the economy started putting downward pressure on inflation. Persistence played a significant role in the first half of 2009, when it prevented headline inflation from contracting further.

- In Japan, persistence prevented headline inflation to contract further in 2009 and 2010, at a time when economic slack and non-commodity imports were putting downward pressure on inflation (Figure A1.8). Non-commodity import prices boosted headline inflation in the second half of 2008 and the first quarter of 2009, while pushing inflation down in the second half of 2009 and in the first quarter of 2010 .

- The main reason why headline inflation has been relatively high in the United Kingdom is inflation persistence (Figure A1.9). Moreover, economic slack started exerting disinflationary pressure only in the second half of 2009 for the output gap measure, and since the fourth quarter of 2008 for the unemployment gap. However, more recently slack has been putting downward pressure on inflation. Import prices, have risen at a fast pace in the United Kingdom (especially on non-commodities imports), most likely due to the depreciation of the sterling.

- In the euro area, persistence has been a main driver of headline inflation until the first half of 2009 and again during the first half of 2010 (Figure A1.10). Economic slack gained importance late in 2008 and in 2009, while import prices, which had positively contributed to inflation until the third quarter of 2008, had a negative impact during the first half of 2009.

\section{Forecasting inflation based on Phillips curve models}

73. Based on the Philips curves estimated before using data until mid 2010, and using the November 2010 projection of explanatory variables in the Economic Outlook No. 88 (output gap, unemployment, and non-commodity prices), headline inflation was forecasted for the four economies under consideration until the end of 2012 (Figures A1.11 to A1.15). The forecasting exercise assumes constant inflation expectations and commodity prices over the forecast horizon.

74. Results of this forecasting exercise point to inflation remaining relatively weak in the near term:

- In the United States, where economic slack will remain high, annual headline inflation is expected to decelerate by $0.15-0.30$ percentage points between the third quarter of 2010 and the end of the forecast horizon.

- In Japan, which has been in deflation for about a decade, the peak up in economic activity is expected to mitigate deflation slightly going forward. The annual headline deflation rate is expected to drop only by some $0.20-0.25$ percentage points between the third quarter of 2010 and the end of 2012, and it seems unlikely that core price inflation will become positive by the end of the forecast horizon. 
- In the United Kingdom, where inflation has been higher than in the other economies, headline inflation is expected to decelerate going forward and to fall below the Bank of England inflation target by the end of the projection period. It should be reminded that the performance of the model is relatively poor in this case and that the projection ere may underestimate headline inflation because the projected VAT increase in January 2011 will certainly boost inflation in the course of 2011.

- In the euro area, inflation is also expected to remain tame. Annual headline inflation is expected to decrease by some 0.6 percentage points between the third quarter of 2010 and the end of 2012, though with a substantial disparity between models.

75. As before, these projections underestimate headline inflation, as far as they do not account for the impact of the substantial commodity price increases and hikes in indirect taxes in some countries during the second half of 2010 and the beginning of 2011. 
Table A1.1. Further description of data used in the empirical analysis

\begin{tabular}{|c|c|c|c|}
\hline Series Title & Description, further information & Adjustment/Type & Source \\
\hline \multicolumn{4}{|l|}{ United States } \\
\hline $\begin{array}{l}\text { Consumer price index } \\
\text { (CPI) }\end{array}$ & $\begin{array}{l}\text { The weights for the CPI are derived from the Consumer Expenditure (CE) Survey } \\
\text { conducted by the Census Bureau. Current period: the average for 2003-04. } \\
\text { Starting from 2002, weights have been revised every other year. Historically } \\
\text { weights have been revised once every } 10 \text { years. Standard Laspeyres aggregation } \\
\text { is used. }\end{array}$ & $\begin{array}{l}\text { S.A., Original BLS base } \\
\text { year } 1982-84=100 \\
\text { converted to } 2005 \text { base } \\
\text { year by OECD }\end{array}$ & $\begin{array}{l}\text { US Bureau of Labor } \\
\text { Statistics (BLS) }\end{array}$ \\
\hline $\begin{array}{l}\text { CPI excluding food and } \\
\text { energy }\end{array}$ & See CPI above. & $\begin{array}{l}\text { S.A., national reference } \\
\text { year is } 1982-1984=100\end{array}$ & $\begin{array}{l}\text { US Bureau of Labor } \\
\text { Statistics }\end{array}$ \\
\hline $\begin{array}{l}\text { Personal consumption } \\
\text { expenditure (PCE) price } \\
\text { index }\end{array}$ & $\begin{array}{l}\text { Reflects the price of expenditures by households, including those made on behalf } \\
\text { of households. Composition of expenditures changes from quarter to quarter. } \\
\text { Weights are derived from business surveys. Derived using a chained Fisher index } \\
\text { formula. }\end{array}$ & $\begin{array}{l}\text { S.A., chain-type price } \\
\text { index, } 2005=100 . \text { Pre- } \\
1995 \text { has been rebased } \\
\text { by OECD }\end{array}$ & $\begin{array}{l}\text { US Bureau of Economic } \\
\text { Analysis (BEA), National } \\
\text { Economic Accounts }\end{array}$ \\
\hline $\begin{array}{l}\text { PCE excluding food and } \\
\text { energy }\end{array}$ & $\begin{array}{l}\text { See PCE price index above. Food consists of food and beverages purchased for } \\
\text { off-premises consumption; food services, which include purchased meals and } \\
\text { beverages, are not classified as food. }\end{array}$ & $\begin{array}{l}\text { S.A., chain-type price } \\
\text { index, } 2005=100 . \\
\text { Pre-1995: rebased by } \\
\text { OECD }\end{array}$ & $\begin{array}{l}\text { US Bureau of Economic } \\
\text { Analysis (BEA), National } \\
\text { Economic Accounts }\end{array}$ \\
\hline $\begin{array}{l}\text { Output gap of the total } \\
\text { economy }\end{array}$ & $\begin{array}{l}\text { The output gap is measured as the percentage difference between actual GDP in } \\
\text { constant prices, and estimated potential GDP. The latter is estimated using a } \\
\text { production function approach with the exact specification varying across countries } \\
\text { depending on data availability. Potential output is estimated using data on capital } \\
\text { services, total factor productivity and potential employment which in part depends } \\
\text { on estimates of the structural rate of unemployment (NAIRU). }\end{array}$ & & OECD \\
\hline Unemployment rate & BLS, Monthly Household Survey - Unemployment Rate, (16 years and older). & S.A. & $\begin{array}{l}\text { US Bureau of Labor } \\
\text { Statistics (BLS) }\end{array}$ \\
\hline
\end{tabular}


ECO/WKP(2011)23

Table A1.1: Further description of data used in the empirical analysis (continued)

\begin{tabular}{|c|c|c|c|}
\hline Series Title & Description, further information & Adjustment/Type & Source \\
\hline $\begin{array}{l}\text { Structural unemployment } \\
\text { rate (non-accelerating } \\
\text { inflation rate of } \\
\text { unemployment) }\end{array}$ & $\begin{array}{l}\text { The structural unemployment rate is defined as the rate of unemployment } \\
\text { consistent with stable inflation (the so-called NAIRU, or non-accelerating inflation } \\
\text { rate of unemployment). The general background to and details of previous OECD } \\
\text { work estimating time-varying NAIRUs within the Phillips curve framework are } \\
\text { given by Richardson et al. (2000). The time-varying NAIRU is obtained via the } \\
\text { estimation of a reduced - form Phillips curve equation using a Kalman filter } \\
\text { procedure. }\end{array}$ & & OECD \\
\hline $\begin{array}{l}\text { Imports of goods and } \\
\text { services, deflator, National } \\
\text { Accounts Basis }\end{array}$ & $\begin{array}{l}\text { Implicit deflator computed as the ratio between value and volume of imports of } \\
\text { goods and services (chain volume index). See note on GDP. }\end{array}$ & S.A., annual levels & $\begin{array}{l}\text { US Bureau of Economic } \\
\text { Analysis (BEA), National } \\
\text { Economic Accounts }\end{array}$ \\
\hline $\begin{array}{l}\text { Price of non-commodity } \\
\text { goods and services } \\
\text { imports }\end{array}$ & $\begin{array}{l}\text { Calculated as the difference between the imports of goods and services deflator } \\
\text { (national accounts basis) and the price of commodity imports (weighted for the } \\
\text { share of commodity imports in the total), divided by the share of non-commodity } \\
\text { imports in the total. }\end{array}$ & & OECD \\
\hline Price of commodity imports & $\begin{array}{l}\text { Calculated based on changes in commodity prices (food, tropical beverages, } \\
\text { agriculture raw materials, minerals, ores and metals) and OECD crude oil import } \\
\text { prices (CIF). }\end{array}$ & & $\begin{array}{l}\text { OECD calculations based } \\
\text { on data from the } \\
\text { Hamburg Institute of } \\
\text { International Economics } \\
\text { (HWWI) }\end{array}$ \\
\hline $\begin{array}{l}\text { Weight of commodities in } \\
\text { goods and services } \\
\text { imports }\end{array}$ & $\begin{array}{l}\text { Calculated as imports of commodities divided by total imports of goods and } \\
\text { services on a national accounts basis. }\end{array}$ & & OECD \\
\hline $\begin{array}{l}\text { Imports of goods and } \\
\text { services, value, National } \\
\text { Accounts basis }\end{array}$ & $\begin{array}{l}\text { Data reported here follow national definitions from the "National Income and } \\
\text { Product Accounts". }\end{array}$ & $\begin{array}{l}\text { Current prices, annual } \\
\text { levels. The quarterly } \\
\text { figures are adjusted for } \\
\text { seasonal and calendar } \\
\text { variations, method X12 } \\
\text { ARIMA. }\end{array}$ & $\begin{array}{l}\text { US Bureau of Economic } \\
\text { Analysis, National } \\
\text { Economic Accounts }\end{array}$ \\
\hline $\begin{array}{l}\text { Gross domestic product, } \\
\text { value, market prices }\end{array}$ & $\begin{array}{l}\text { Data reported here follow national definitions from the "National Income and } \\
\text { Product Accounts". }\end{array}$ & $\begin{array}{l}\text { Current prices, annual } \\
\text { levels. The quarterly } \\
\text { figures are adjusted for } \\
\text { seasonal and calendar } \\
\text { variations, method X12 } \\
\text { ARIMA. }\end{array}$ & $\begin{array}{l}\text { US Bureau of Economic } \\
\text { Analysis (BEA) National } \\
\text { Income and Product } \\
\text { Accounts }\end{array}$ \\
\hline
\end{tabular}


Table A1.1: Further description of data used in the empirical analysis (continued)

\begin{tabular}{|c|c|c|c|}
\hline Series Title & Description, further information & Adjustment/Type & Source \\
\hline \multicolumn{4}{|l|}{ Euro area } \\
\hline $\begin{array}{l}\text { Consumer price index, } \\
\text { harmonised (HICP) }\end{array}$ & $\begin{array}{l}\text { The coverage of the HICPs is defined in terms of 'household final monetary } \\
\text { consumption expenditure', by reference to the national accounts concept of the } \\
\text { European System of Accounts (ESA 1995). The index covers all forms of } \\
\text { household expenditure, net of reimbursements, subsidies and discounts. Spending } \\
\text { by foreign visitors, including tourists and cross-border shoppers in the economic } \\
\text { territory of the member state, is included. }\end{array}$ & $\begin{array}{l}\text { Reference year } \\
2005 . \text { Seasonally } \\
\text { adjusted with x11default } \\
\text { by OECD }\end{array}$ & Eurostat \\
\hline $\begin{array}{l}\text { Core inflation index, } \\
\text { harmonised excluding } \\
\text { energy, food, alcohol and } \\
\text { tobacco }\end{array}$ & See CPIH. & $\begin{array}{l}\text { Reference year } 2005 \text {, } \\
\text { S.A. }\end{array}$ & Eurostat \\
\hline Unemployment rate & $\begin{array}{l}\text { Weighted average of unemployment rates of } 14 \text { euro area countries. Weights } \\
\text { based on shares of labour force in total area labour force for each period. }\end{array}$ & & OECD \\
\hline $\begin{array}{l}\text { Output gap of the total } \\
\text { economy }\end{array}$ & $\begin{array}{l}\text { The output gap is measured as the percentage difference between actual GDP in } \\
\text { constant prices, and estimated potential GDP. The latter is estimated using a } \\
\text { production function approach with the exact specification varying across countries } \\
\text { depending on data availability. Potential output is estimated using data on capital } \\
\text { services, total factor productivity and potential employment which in part depends } \\
\text { on estimates of the structural rate of unemployment (NAIRU). }\end{array}$ & & OECD \\
\hline $\begin{array}{l}\text { Structural unemployment } \\
\text { rate (non-accelerating } \\
\text { inflation rate of } \\
\text { unemployment) }\end{array}$ & $\begin{array}{l}\text { The structural unemployment rate is defined as the rate of unemployment } \\
\text { consistent with stable inflation (the so-called NAIRU, or non-accelerating inflation } \\
\text { rate of unemployment). The general background to and details of previous OECD } \\
\text { work estimating time-varying NAIRUs within the Phillips curve framework are given } \\
\text { by Richardson et al. (2000). The time-varying NAIRU is obtained via the estimation } \\
\text { of a reduced form Phillips curve equation using a Kalman filter procedure. }\end{array}$ & & OECD \\
\hline $\begin{array}{l}\text { Imports of goods and } \\
\text { services, deflator, national } \\
\text { accounts basis }\end{array}$ & $\begin{array}{l}\text { Calculation based on the sum of value and volume of imports for euro area } \\
\text { countries. These data are currently not consolidated for intra-EU trade. }\end{array}$ & & OECD \\
\hline $\begin{array}{l}\text { Imports of goods and } \\
\text { services, value, National } \\
\text { Accounts basis }\end{array}$ & $\begin{array}{l}\text { Sum of import values of euro area countries. These data are currently not } \\
\text { consolidated for intra-EU trade. }\end{array}$ & & OECD \\
\hline
\end{tabular}


ECO/WKP(2011)23

Table A1.1: Further description of data used in the empirical analysis (continued)

\begin{tabular}{|c|c|c|c|}
\hline Series Title & Description, further information & Adjustment/Type & Source \\
\hline \multicolumn{4}{|l|}{ Japan } \\
\hline $\begin{array}{l}\text { Consumer price index } \\
(\mathrm{CPI})\end{array}$ & $\begin{array}{l}\text { The monthly index measures the general level of prices of goods and services that } \\
\text { households acquire for consumption, based on } 585 \text { items. Type of prices: Normal } \\
\text { retail prices or service charges for items actually sold in establishments on the } \\
\text { survey date; excludes temporary bargain (within a week) prices, prices for } \\
\text { installment sales, abnormal prices due to disasters, and prices of second-hand } \\
\text { articles. Method of collection: the monthly Retail Price Survey (RPS) is the main } \\
\text { source of data on prices for the CPI. }\end{array}$ & $\begin{array}{l}\text { National reference year } \\
2005 \text {. Seasonally } \\
\text { adjusted using the X-11 } \\
\text { seasonal adjustment } \\
\text { method }\end{array}$ & $\begin{array}{l}\text { Statistics Bureau of } \\
\text { Japan }\end{array}$ \\
\hline $\begin{array}{l}\text { CPI excluding food and } \\
\text { energy }\end{array}$ & $\begin{array}{l}\text { CPI all items less Food less Energy is computed by OECD using } 2005 \text { weights } \\
\text { and components provided by the Statistics Bureau of Japan. See CPI above for } \\
\text { further information. }\end{array}$ & $\begin{array}{l}\text { National reference year } \\
2005 \text {. Seasonally } \\
\text { adjusted using the X-11 } \\
\text { seasonal adjustment } \\
\text { method. }\end{array}$ & $\begin{array}{l}\text { Statistics Bureau of } \\
\text { Japan }\end{array}$ \\
\hline $\begin{array}{l}\text { Output gap of the total } \\
\text { economy }\end{array}$ & $\begin{array}{l}\text { The output gap is measured as the percentage difference between actual GDP in } \\
\text { constant prices, and estimated potential GDP. The latter is estimated using a } \\
\text { production function approach with the exact specification varying across countries } \\
\text { depending on data availability. Potential output is estimated using data on capital } \\
\text { services, total factor productivity and potential employment which in part depends } \\
\text { on estimates of the structural rate of unemployment (NAIRU). }\end{array}$ & & OECD \\
\hline Unemployment rate & $\begin{array}{l}\text { Data refer to persons aged } 15 \text { years and over. The national defense forces and } \\
\text { inmates of reformatory institutions are separately enumerated and included in the } \\
\text { results. Full and part-time workers seeking other work during the reference week } \\
\text { and students working full or part-time are also included. National self-defense } \\
\text { forces are included in Employees. }\end{array}$ & & $\begin{array}{l}\text { Statistics Bureau of } \\
\text { Japan, Household } \\
\text { Labour Force Survey }\end{array}$ \\
\hline
\end{tabular}


Table A1.1. Further description of data used in the empirical analysis (continued)

\begin{tabular}{|c|c|c|c|}
\hline Series Title & Description, further information & Adjustment/Type & Source \\
\hline $\begin{array}{l}\text { Structural unemployment } \\
\text { rate (non-accelerating } \\
\text { inflation rate of } \\
\text { unemployment) }\end{array}$ & $\begin{array}{l}\text { The structural unemployment rate is defined as the rate of unemployment } \\
\text { consistent with stable inflation (the so-called NAIRU, or non-accelerating inflation } \\
\text { rate of unemployment). The general background to and details of previous OECD } \\
\text { work estimating time-varying NAIRUs within the Phillips curve framework are given } \\
\text { by Richardson et al. ( } 2000 \text { ). The time-varying NAIRU is obtained via the estimation } \\
\text { of a reduced form Phillips curve equation using a Kalman filter procedure. }\end{array}$ & & \\
\hline $\begin{array}{l}\text { Imports of goods and } \\
\text { services, deflator, national } \\
\text { accounts basis }\end{array}$ & $\begin{array}{l}\text { Implicit deflator computed as the ratio between value and volume of imports of } \\
\text { goods and services (chain volume index). }\end{array}$ & Reference year 2000. & $\begin{array}{l}\text { Economic and Social } \\
\text { Research Institute } \\
\text { (ESRI), Cabinet Office } \\
\text { (CAO) }\end{array}$ \\
\hline $\begin{array}{l}\text { Price of non-commodity } \\
\text { goods and services } \\
\text { imports }\end{array}$ & $\begin{array}{l}\text { Calculated as the difference between the imports of goods and services deflator } \\
\text { (national accounts basis) and the price of commodity imports (weighted for the } \\
\text { share of commodity imports in the total), divided by the share of non-commodity } \\
\text { imports in the total. }\end{array}$ & & OECD \\
\hline $\begin{array}{l}\text { Price of commodity } \\
\text { imports }\end{array}$ & $\begin{array}{l}\text { Calculated based on non-oil commodity prices (food, tropical beverages, } \\
\text { agriculture raw materials, minerals, ores and metals) and OECD crude oil import } \\
\text { prices (CIF). }\end{array}$ & & $\begin{array}{l}\text { OECD calculations based } \\
\text { on data from the } \\
\text { Hamburg Institute of } \\
\text { International Economics } \\
\text { (HWWI) }\end{array}$ \\
\hline $\begin{array}{l}\text { Weight of commodities in } \\
\text { goods and services } \\
\text { imports }\end{array}$ & $\begin{array}{l}\text { Calculated as imports of commodities divided by total imports of goods and } \\
\text { services on a national accounts basis. }\end{array}$ & & OECD \\
\hline $\begin{array}{l}\text { Imports of goods and } \\
\text { services, value, National } \\
\text { Accounts basis }\end{array}$ & Based on SNA 93 methodology. & $\begin{array}{l}\text { Adjusted for seasonal } \\
\text { and calendar variations, } \\
\text { method X12 ARIMA. }\end{array}$ & $\begin{array}{l}\text { Economic and Social } \\
\text { Research Institute } \\
\text { (ESRI), Cabinet Office } \\
\text { (CAO) }\end{array}$ \\
\hline
\end{tabular}


ECO/WKP(2011)23

Table A1.1 Further description of data used in the empirical analysis (continued)

\begin{tabular}{|c|c|c|c|}
\hline Series Title & Description, further information & Adjustment/Type & Source \\
\hline \multicolumn{4}{|l|}{ United Kingdom } \\
\hline $\begin{array}{l}\text { Consumer price index, } \\
\text { harmonised (HICP) }\end{array}$ & $\begin{array}{l}\text { The coverage of the HICPs is defined in terms of 'household final monetary } \\
\text { consumption expenditure', by reference to the national accounts concept of the } \\
\text { European System of Accounts (ESA 1995). The index covers all forms of } \\
\text { household expenditure, net of reimbursements, subsidies and discounts. Spending } \\
\text { by foreign visitors including tourists and cross-border shoppers in the economic } \\
\text { territory of the member state, is included. Data prior to } 1988 \text { are estimates of } \\
\text { "indicative HICP" based on RPI indices and weights, and published by the ONS in } \\
\text { 'Economic Trends' No. 541, December 1998. }\end{array}$ & $\begin{array}{l}\text { Reference year } 2005, \\
\text { Seasonally adjusted by } \\
\text { SA x11method }\end{array}$ & $\begin{array}{l}\text { Office for National } \\
\text { Statistics (ONS), United } \\
\text { Kingdom }\end{array}$ \\
\hline $\begin{array}{l}\text { Core inflation index, } \\
\text { harmonised (core HICP) } \\
\text { excluding energy, food, } \\
\text { alcohol and tobacco }\end{array}$ & See HICP. These data have not been extended backwards. & $\begin{array}{l}\text { Reference year } 2005 \text {, } \\
\text { Seasonally adjusted by } \\
\text { SA x11 method by }\end{array}$ & $\begin{array}{l}\text { Office for National } \\
\text { Statistics (ONS), United } \\
\text { Kingdom }\end{array}$ \\
\hline $\begin{array}{l}\text { Gross domestic product, } \\
\text { value, market prices }\end{array}$ & & $\begin{array}{l}\text { Chained volume } \\
\text { estimates, national } \\
\text { reference year } 2006 \text {, } \\
\text { quarterly levels } \\
\text { annualised by OECD. } \\
\text { The quarterly figures are } \\
\text { adjusted for seasonal } \\
\text { and calendar variations, } \\
\text { method X12 ARIMA }\end{array}$ & $\begin{array}{l}\text { Office for National } \\
\text { Statistics (ONS), United } \\
\text { Kingdom }\end{array}$ \\
\hline $\begin{array}{l}\text { Output gap of the total } \\
\text { economy }\end{array}$ & $\begin{array}{l}\text { The output gap is measured as the percentage difference between actual GDP in } \\
\text { constant prices, and estimated potential GDP. The latter is estimated using a } \\
\text { production function approach with the exact specification varying across countries } \\
\text { depending on data availability. Potential output is estimated using data on capital } \\
\text { services, total factor productivity and potential employment which in part depends } \\
\text { on estimates of the structural rate of unemployment (NAIRU). }\end{array}$ & & OECD \\
\hline Unemployment rate & Mid-trimester data, population age 15 years and over. & $\begin{array}{l}\text { Seasonal adjustment of } \\
\text { LFS estimates have } \\
\text { been carried out using } \\
\text { X-11 ARIMA }\end{array}$ & $\begin{array}{l}\text { Office for National } \\
\text { Statistics (ONS), United } \\
\text { Kingdom }\end{array}$ \\
\hline
\end{tabular}




\begin{tabular}{|c|c|c|c|}
\hline Series Title & Description, further information & Adjustment/Type & Source \\
\hline $\begin{array}{l}\text { Structural unemployment } \\
\text { rate (non-accelerating } \\
\text { inflation rate of } \\
\text { unemployment) }\end{array}$ & $\begin{array}{l}\text { The structural unemployment rate is defined as the rate of unemployment } \\
\text { consistent with stable inflation (the so-called NAIRU, or non-accelerating inflation } \\
\text { rate of unemployment). The general background to and details of previous OECD } \\
\text { work estimating time-varying NAIRUs within the Phillips curve framework are given } \\
\text { by Richardson et al. (2000). The time-varying NAIRU is obtained via the estimation } \\
\text { of a reduced form Phillips curve equation using a Kalman filter procedure. }\end{array}$ & & OECD \\
\hline $\begin{array}{l}\text { Imports of goods and } \\
\text { services, deflator, national } \\
\text { accounts basis }\end{array}$ & $\begin{array}{l}\text { Implicit deflator computed as the ratio between value and volume of imports of } \\
\text { goods and services (chain volume index). }\end{array}$ & $\begin{array}{l}\text { Chained volume } \\
\text { estimates, national } \\
\text { reference year } 2006 \text {. The } \\
\text { quarterly figures are } \\
\text { adjusted for seasonal } \\
\text { and calendar variations, } \\
\text { method X12 ARIMA, } \\
\text { annualised by OECD }\end{array}$ & $\begin{array}{l}\text { Office for National } \\
\text { Statistics (ONS), United } \\
\text { Kingdom }\end{array}$ \\
\hline $\begin{array}{l}\text { Price of non-commodity } \\
\text { goods and services } \\
\text { imports }\end{array}$ & $\begin{array}{l}\text { Calculated as the difference between the imports of goods and services deflator } \\
\text { (national accounts basis) and the price of commodity imports (weighted for the } \\
\text { share of commodity imports in the total), divided by the share of non-commodity } \\
\text { imports in the total. }\end{array}$ & & OECD \\
\hline $\begin{array}{l}\text { Price of commodity } \\
\text { imports }\end{array}$ & $\begin{array}{l}\text { Calculated based on non-oil commodity prices (food, tropical beverages, } \\
\text { agriculture raw materials, minerals, ores and metals) and OECD crude oil import } \\
\text { prices (CIF). }\end{array}$ & & $\begin{array}{l}\text { OECD calculations based } \\
\text { on data from the } \\
\text { Hamburg Institute of } \\
\text { International Economics } \\
\text { (HWWI) }\end{array}$ \\
\hline $\begin{array}{l}\text { Weight of commodities in } \\
\text { goods and services } \\
\text { imports }\end{array}$ & $\begin{array}{l}\text { Calculated as imports of commodities divided by total imports of goods and } \\
\text { services on a national accounts basis. }\end{array}$ & & OECD \\
\hline $\begin{array}{l}\text { Imports of goods and } \\
\text { services, value, National } \\
\text { Accounts basis }\end{array}$ & & $\begin{array}{l}\text { Current prices, quarterly } \\
\text { levels annualised by } \\
\text { OECD. The quarterly } \\
\text { figures are adjusted for } \\
\text { seasonal and calendar } \\
\text { variations, method X12 } \\
\text { ARIMA }\end{array}$ & $\begin{array}{l}\text { Office for National } \\
\text { Statistics (ONS), United } \\
\text { Kingdom }\end{array}$ \\
\hline
\end{tabular}


ECO/WKP(2011)23

Table A1.2. Models for headline CPI inflation in the United States

Dep. Var. : Q/Q annualised headline CPI inflation

\begin{tabular}{|c|c|c|c|}
\hline Variable & Model 1 & Model 2 & Model 3 \\
\hline$\pi_{t-1}$ & $-0.33^{*}$ & & $-0.33^{*}$ \\
\hline$\pi_{t-3}$ & & & $0.10^{*}$ \\
\hline$\pi_{t, t+1}^{e}$ & $1.47^{* * *}$ & $0.92^{* * *}$ & $1.30^{* * *}$ \\
\hline$y_{t-1}$ & $0.26^{* *}$ & --- & --- \\
\hline$u_{t}$ & --- & $-0.30^{* * *}$ & --- \\
\hline$u r_{t}$ & -- & -- & $-1.21^{* *}$ \\
\hline$u r_{t-1}$ & --- & -- & $0.98^{*}$ \\
\hline$w_{c i p}$ & $0.85^{\star * *}$ & $1.16^{\star * *}$ & $0.90^{* * *}$ \\
\hline $\begin{array}{l}\text { wcip }_{t-1} \\
\text { Constant }\end{array}$ & $\begin{array}{l}0.77^{* * *} \\
-0.91^{*}\end{array}$ & & $\begin{array}{l}0.90^{\star * *} \\
-0.54\end{array}$ \\
\hline \multicolumn{4}{|l|}{ Diagnostic tests } \\
\hline $\begin{array}{l}\text { Nr. of obs. } \\
\text { Log. Likelihood }\end{array}$ & $\begin{array}{c}113 \\
-173.61\end{array}$ & $\begin{array}{l}113 \\
-185.07\end{array}$ & $\begin{array}{l}113 \\
-164.03\end{array}$ \\
\hline $\begin{array}{l}\sigma^{2} \\
P Q(1) \\
P Q(4) \\
A R C H(1) \\
A R C H(4)\end{array}$ & $\begin{array}{l}1.30 \\
0.31 \\
2.17 \\
0.21 \\
2.85\end{array}$ & $\begin{array}{c}1.55 \\
0.06 \\
0.84 \\
8.15^{\star * \star} \\
14.073^{\star \star \star}\end{array}$ & $\begin{array}{l}1.30 \\
0.03 \\
1.95 \\
1.71 \\
3.59\end{array}$ \\
\hline Normality (KS) & 0.06 & 0.09 & 0.05 \\
\hline
\end{tabular}

Note: The estimation sample spans the period $1982 q 3$ to $2010 q 3$. The most general model estimated is given by: $\pi_{t}=\delta+\phi(L) \pi_{t-1}+\beta \pi_{t, t+1}^{e}+\mu(L)\left(w_{\text {cip }}\right)+\lambda(L)\left(\right.$ wncip $\left._{t}\right)+\alpha(L) x_{t}+\varphi(L) \varepsilon_{t}$, where $\pi_{t}$ is the annualised quarter-on-quarter inflation rate, $\delta_{\text {is a constant, }} \pi_{t, t+1}^{e}$ is annualised expected inflation between quarter $\mathrm{t}$ and $\mathrm{t}+1, w^{2}{ }^{2} p_{t}$ and wncip $_{t}$ are the annualised rate of growth of commodity and non-commodity weighted import prices, and $x_{t}$ is a measure of economic activity (given by the output gap $\left({ }^{y_{t}}\right)$ in Model 1, the unemployment gap $\left({ }^{u_{t}}\right)$ in Model 2, and the unemployment recession gap $\left({ }^{u r_{t}}\right.$ ) in Model 3). $\phi(L), \mu(L), \lambda(L)$ and $\alpha(L)$ are lag polynomials. Moving average parameters for the error terms not reported. $\sigma^{2}$ is the mean square error. $\mathrm{PQ}(\mathrm{i})$ and $\mathrm{ARCH}(\mathrm{i})$ are the Portmanteau and LM test statistics for residual autocorrelation and conditional heteroscedasticity of order $i$, respectively. Normality (KS) is the Kolmogorov-Smirnov test for the null hypothesis of normal residuals. $\left(^{*}\right),\left({ }^{* *}\right)$ and $\left(^{* \star *}\right)$ denote statistical significance (using robust standard errors) at the $10 \%, 5 \%$ and $1 \%$ levels, respectively.

Source: Authors' calculations. 
Table A1.3. Models for headline PCE inflation in the United States

Dep. Var.: Q/Q annualised headline PCE inflation

\begin{tabular}{lcc}
\hline \multicolumn{1}{c}{ Variable } & Model 1 & Model 2 \\
\hline$\pi_{t-1}$ & $-0.27^{*}$ & \\
$\pi_{t-4}$ & $0.14^{*}$ & \\
$\pi_{t, t+1}^{e}$ & $1.05^{* * *}$ & $0.99^{* * *}$ \\
$y_{t}$ & $0.35^{* *}$ & \\
$y_{t-2}$ & $-0.25^{*}$ & \\
$u_{t-2}$ & & \\
$u_{t-3}$ & & $-0.98^{* *}$ \\
$u_{t-4}$ & & $2.04^{* * *}$ \\
$w c i p_{t}$ & & $-1.14^{* * *}$ \\
$w c i p_{t-1}$ & & $0.72^{* * *}$ \\
wncip & & $0.20^{*}$ \\
Constant & $0.70^{* * *}$ & $0.35^{* *}$ \\
Diagnostic tests & $0.41^{*}$ & $-0.66^{*}$ \\
Nr. of obs. & $0.54^{* *}$ & 113 \\
Log. Likelihood & $-0.58^{*}$ & -135.57 \\
$\sigma^{2}$ & 113 & 0.70 \\
PQ(1) & -129.30 & $3.14^{*}$ \\
PQ(4) & 0.63 & $9.77^{* *}$ \\
ARCH(1) & 0.11 & 0.28 \\
ARCH(4) & 0.66 & 1.05 \\
Normality (KS) & $4.14^{* *}$ & 0.10 \\
\hline
\end{tabular}

Note: $\quad$ The estimation sample spans the period 1982q3 to 2010q3. The most general model estimated is given by:

$\pi_{t}=\delta+\phi(L) \pi_{t-1}+\beta \pi_{t, t+1}^{e}+\mu(L)\left(\right.$ wcip $\left._{t}\right)+\lambda(L)\left(\right.$ wncip $\left._{t}\right)+\alpha(L) x_{t}+\varphi(L) \varepsilon_{t}$, where $\pi_{t}$ is the annualised quarteron-quarter inflation rate, $\delta$ is a constant, $\pi_{t, t+1}^{e}$ is annualised expected inflation between quarter $\mathrm{t}$ and $\mathrm{t}+1, \quad w{ }^{2} p_{t}$ and wncip $_{t}$ are the annualised rate of growth of commodity and non-commodity weighted import prices, and $x_{t}$ is a measure of economic activity (given by the output gap $\left({ }^{y_{t}}\right)$ in Model 1 and the unemployment gap $\left({ }^{u_{t}}\right)$ in Model 2, and the unemployment recession gap $\left({ }^{u r_{t}}\right.$ ) in Model 3). $\phi(L), \mu(L), \lambda(L)$ and $\alpha(L)$ are lag polynomials. Moving average parameters for the error terms not reported. $\sigma^{2}$ is the mean square error. $\mathrm{PQ}(\mathrm{i})$ and $\mathrm{ARCH}(\mathrm{i})$ are the Portmanteau and LM test statistic for residual autocorrelation and conditional heteroscedasticity of order i, respectively. Normality (KS) is the Kolmogorov-Smirnov test for the nul hypothesis of normal residuals. $\left(^{*}\right),\left(^{* *}\right)$ and ${ }^{* * *}$ ) denote statistical significance (using robust standard errors) at the $10 \%, 5 \%$ and $1 \%$ levels, respectively.

Source: Authors' calculations. 
Table A1.4. Models for headline CPI inflation in Japan

Dep. Var.: $\mathrm{Y} / \mathrm{Y}$ headline $\mathrm{CPI}$ inflation

\begin{tabular}{|c|c|c|c|}
\hline Variable & Model 1 & Model 2 & Model 3 \\
\hline$y_{t}$ & $0.11^{* * *}$ & --- & --- \\
\hline$y_{t-2}$ & $0.09^{* *}$ & --- & --- \\
\hline$(1 / U R)_{t}$ & --- & $12.65^{\star * *}$ & --- \\
\hline$(1 / U R)_{t-2}$ & --- & $6.47^{*}$ & --- \\
\hline$(1 / U R)_{t-4}$ & --- & $-16.70^{* * *}$ & --- \\
\hline$u r_{t}$ & & --- & $-1.24^{* * *}$ \\
\hline$u r_{t-4}$ & & --- & $0.89^{* * *}$ \\
\hline$w_{c i p}{ }_{t-1}$ & $0.04^{* *}$ & $0.13^{* * *}$ & $0.05^{\star *}$ \\
\hline$w_{c i p}{ }_{t-2}$ & & $0.11^{* * *}$ & --- \\
\hline$w_{c i p}{ }_{t-3}$ & & $0.14^{* * *}$ & --- \\
\hline$w_{c i p}{ }_{t-4}$ & $0.03^{*}$ & $0.16^{* * *}$ & $0.04^{* *}$ \\
\hline$w_{n c i p}$ & $0.22^{* * *}$ & & $0.15^{\star * *}$ \\
\hline wncip $_{t-1}$ & $0.24^{* * *}$ & & $0.19^{* * *}$ \\
\hline$w_{n c i p}{ }_{t-2}$ & $0.27^{* * *}$ & & $0.19^{* * *}$ \\
\hline wncip $_{t-3}$ & $0.21^{* * *}$ & $0.06^{* *}$ & $0.18^{* * *}$ \\
\hline Constant & -0.21 & $-1.08^{* *}$ & -0.07 \\
\hline \multicolumn{4}{|l|}{ Diagnostic tests } \\
\hline Nr. of obs. & 112 & 112 & 112 \\
\hline Log. Likelihood & -46.41 & -42.54 & -45.63 \\
\hline$\sigma^{2}$ & 0.16 & 0.15 & 0.15 \\
\hline$P Q(1)$ & $4.19^{* *}$ & 2.23 & 1.71 \\
\hline$P Q(4)$ & $11.36^{* *}$ & $10.27^{* *}$ & $8.98^{*}$ \\
\hline $\mathrm{ARCH}(1)$ & $6.05^{* *}$ & 2.28 & 0.56 \\
\hline $\mathrm{ARCH}(4)$ & 1.78 & 4.04 & 5.25 \\
\hline Normality (KS) & 0.09 & 0.06 & 0.09 \\
\hline
\end{tabular}

Note: The estimation sample spans the period 1982q3 to 2010q2. The most general model estimated is given by: $\pi_{t+4}^{4}=\delta+\pi_{t}+\phi(L) \Delta \pi_{t}+\beta \pi_{t, t+1}^{e}+\mu(L)\left(w c i p_{t+4}\right)+\lambda(L)\left(w_{n c i p} p_{t+4}\right)+\alpha(L) x_{t+4}+D u m 89+D u m 97+\varphi(L) \varepsilon_{t+4}$ where $\Delta$ is the first difference operator, $\pi_{t}^{4}$ is annual inflation, $\pi_{t}$ is the annualised quarter-on-quarter inflation rate, $\pi_{t, t+1}^{e}$ is expected inflation, wcip $_{t}$ and wncip $_{t}$ are the annualised rate of growth of commodity and non-commodity weighted import prices, and $x_{t}$ is a measure of economic activity (output gap $\left(y_{t}\right)$ in Model 1 , inverse of the unemployment rate $\left((1 / U R)_{t}\right)$ in Model 2 , and unemployment recession gap $\left(u r_{t}\right)$ in Model 3). Dum89 and Dum97 are dummies accounting for consumption tax changes in the second quarter of 1989 and in 1997, respectively. $\phi(L), \mu(L), \lambda(L), \alpha(L)$ and $\varphi(L)$ are lag polynomials. Lagged values of inflation, moving average for the error terms and consumption tax dummies not reported. $\sigma^{2}$ is the mean square error. $P Q(i)$ and $A R C H$ (i) are the Portmanteau and LM test statistic for residual autocorrelation and conditional heteroscedasticity of order $i$, respectively. Normality (KS) is the Kolmogorov-Smirnov test for the null hypothesis of normal residuals. $\left({ }^{\star}\right),\left(^{* \star}\right)$ and $\left({ }^{\star * *}\right)$ denote statistical significance (using robust standard errors) at the $10 \%, 5 \%$ and $1 \%$ levels, respectively.

Source: Authors' calculations. 
Table A1.5. Models for headline CPI inflation in the United Kingdom

Dep. Var.: Q/Q annualised headline CPI inflation

\begin{tabular}{|c|c|c|}
\hline Variable & Model 1 & Model 2 \\
\hline$\pi_{t-2}$ & $0.17^{* * *}$ & $0.21^{* * *}$ \\
\hline$\pi_{t-4}$ & $0.49^{* * *}$ & $0.45^{* \star *}$ \\
\hline$y_{t-1}$ & $0.33^{\star \star *}$ & \\
\hline$u_{t-1}$ & & $-0.46^{* *}$ \\
\hline$w_{c i p}$ & & $0.37^{\star *}$ \\
\hline$w_{c i p} p_{t-3}$ & $0.23^{*}$ & \\
\hline$w_{c i p}-4$ & $-0.29^{\star *}$ & \\
\hline wncip $_{t}$ & $0.21^{\star *}$ & \\
\hline wncip $_{t-2}$ & $0.32^{* * *}$ & $0.22^{*}$ \\
\hline Constant & $0.72^{* * *}$ & $0.79^{* * *}$ \\
\hline $\begin{array}{l}\text { Diagnostic tests } \\
\text { Nr. of obs. } \\
\text { Log. Likelihood }\end{array}$ & $\begin{array}{c}115 \\
-214.05\end{array}$ & $\begin{array}{c}115 \\
-227.28\end{array}$ \\
\hline $\begin{array}{l}\sigma^{2} \\
P Q(1) \\
P Q(4) \\
A R C H(1) \\
\text { ARCH(4) } \\
\text { Normality (KS) }\end{array}$ & $\begin{array}{l}2.42 \\
0.32 \\
4.50 \\
0.05 \\
8.69^{*} \\
0.14^{* *} \\
\end{array}$ & $\begin{array}{c}3.05 \\
3.04^{*} \\
5.22 \\
0.06 \\
10.91^{* *} \\
0.11^{*} \\
\end{array}$ \\
\hline
\end{tabular}

Note: The estimation sample spans the period 1981q4 to 2010q2. The most general model estimated is given by: $\pi_{t}=\delta+\phi(L) \pi_{t-1}+\mu(L)\left(w_{\text {cip }}\right)+\lambda(L)\left(w_{t}\right)$ ip $\left._{t}\right)+\alpha(L) x_{t}+D u m 08+D u m 10+\varphi(L) \varepsilon_{t}$, where $\pi_{t}$ is the annualised quarter-on-quarter inflation rate, $\delta$ is a constant, wcip $_{t}$ and wncip $_{t}$ are the annualised rate of growth of commodity and non-commodity weighted import prices, and $x_{t}$ is a measure of economic activity (given by the output gap $\left(y_{t}\right)$ in Model 1 and the unemployment gap $\left(u_{t}\right)$ in Model 2). Dum08 and Dum10 are two dummies (not reported) for the VAT cut and increase in the fourth quarter of 2008 and the first quarter of 2010, respectively. $\phi(L), \mu(L), \lambda(L), \alpha(L)$ and $\varphi(L)$ are lag polynomials. Moving average for the error terms not reported. $\sigma^{2}$ is the mean square error. $\mathrm{PQ}(i)$ and $A R C H(i)$ are the Portmanteau and LM test statistic for residual autocorrelation and conditional heteroscedasticity of order $i$, respectively. Normality (KS) is the KolmogorovSmirnov test for the null hypothesis of normal residuals. $\left({ }^{*}\right),\left({ }^{* *}\right)$ and $\left({ }^{* * *}\right)$ denote statistical significance (using robust standard errors) at the $10 \%, 5 \%$ and $1 \%$ levels, respectively.

Source: Authors' calculations. 
ECO/WKP(2011)23

Table A1.6. Models for headline CPI inflation in the euro area

Dep. Var.: Q/Q annualised headline CPI inflation

\begin{tabular}{lcc}
\hline \multicolumn{1}{c}{ Variable } & Model 1 & Model 2 \\
\hline$\Delta \pi_{t-1}$ & $-0.57^{* * *}$ & $-0.83^{* * *}$ \\
$y_{t}$ & $0.55^{*}$ & \\
$y_{t-1}$ & $-0.55^{*}$ & \\
$u_{t}$ & & $-0.33^{* * *}$ \\
$i p_{t}$ & & $0.19^{* * *}$ \\
$i p_{t-2}$ & $0.09^{* *}$ & $-0.17^{* * *}$ \\
$i p_{t-3}$ & & $0.45^{* *}$ \\
\hline Diagnostic tests & & \\
Nr. of obs. & & 46 \\
Log. Likelihood & 46 & -48.34 \\
$\sigma^{2}$ & -64.00 & 0.46 \\
PQ(1) & 1.16 & 0.92 \\
PQ(4) & 0.11 & 5.53 \\
ARCH(1) & $10.15^{*}$ & 0.28 \\
ARCH(4) & 0.4 & 3.11 \\
Normality (KS) & 6.37 & 0.08 \\
\hline
\end{tabular}

Note: The estimation sample spans the period 1999q1 to 2010q2. The most general model estimated is given by: $\Delta \pi_{t}=\delta+\phi(L) \Delta \pi_{t-1}+\pi_{t, t+4}^{e}+\mu(L)\left(i p_{t}\right)+\alpha(L) x_{t}+\varphi(L) \varepsilon_{t}$, where $\Delta$ is the first difference operator, $\pi_{t}$ is the annualised quarter-on-quarter inflation rate, $\delta$ is a constant, $\pi_{t, t+4}^{e}$ is expected inflation at time $t$, between quarter $t$ and $t+4$, $i p_{t}$ is the annualised rate of growth of import prices, and $x_{t}$ is a measure of economic activity (given by the output gap $\left(y_{t}\right)$ in Model 1 and the unemployment gap $\left(u_{t}\right)$ in Model 2). Moving average parameters for the error not reported. In Model 1 , the restriction that the coefficient of $y_{t}$ and $y_{t-1}$ are equal but opposite in sign cannot be rejected (p-value equal to 0.70). $\phi(L), \mu(L), \alpha(L)$ and $\varphi(L)$ are lag polynomials. $\sigma^{2}$ is the mean square error. $\mathrm{PQ}(i)$ and $A R C H(i)$ are the Portmanteau and LM test statistic for residual autocorrelation and conditional heteroscedasticity of order $i$, respectively. Normality (KS) is the Kolmogorov-Smirnov test for the null hypothesis of normal residuals. $\left.\left(^{*}\right),{ }^{* *}\right)$ and $\left(^{* * *}\right)$ denote statistical significance (using robust standard errors) at the $10 \%, 5 \%$ and $1 \%$ levels, respectively.

Source: Authors' calculations. 
Figure A1.1. Actual and fitted values for headline CPI inflation in the United States Dep. Var.: Q/Q annualised headline CPI inflation (per cent)
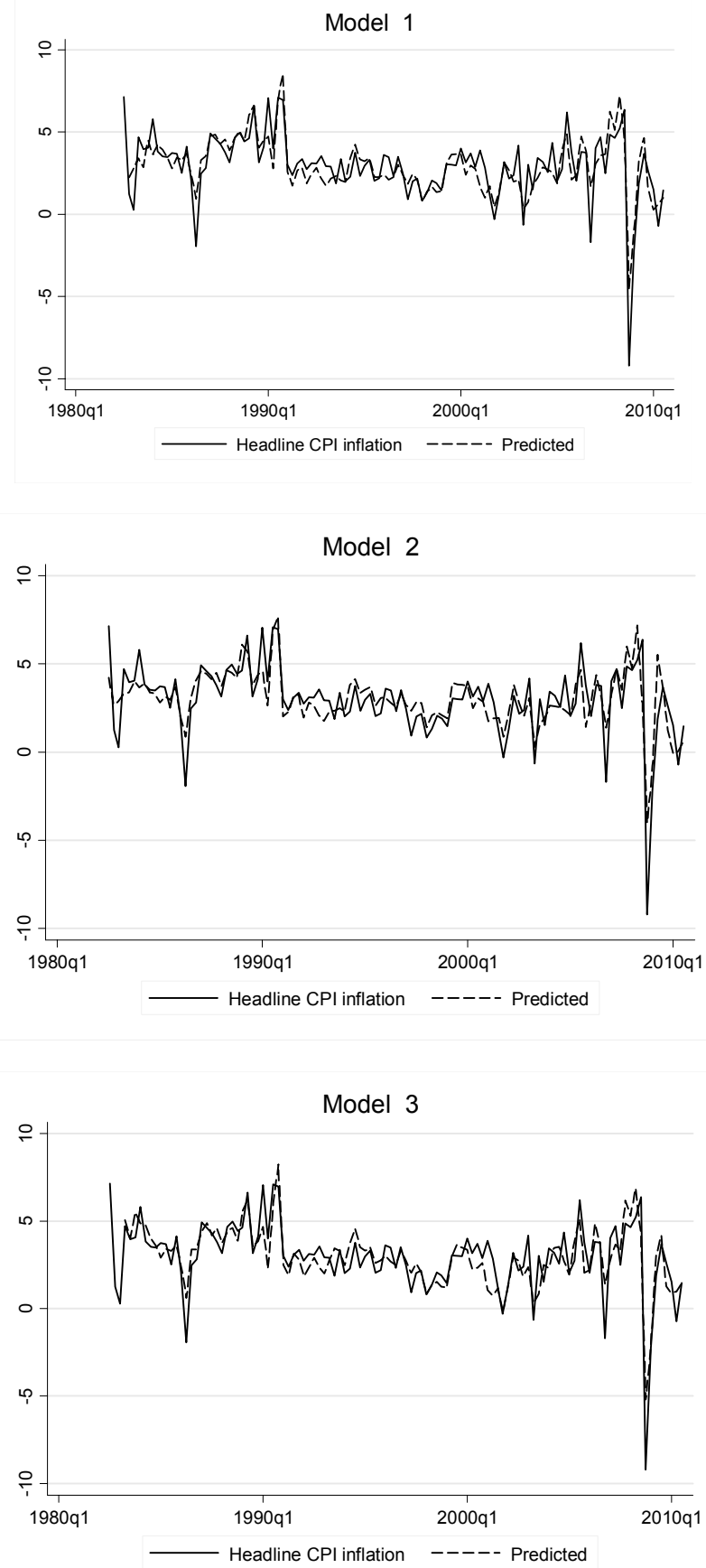

Note: Fitted values are obtained from Models 1, 2 and 3 estimated in Table A1.2.

Source: Authors' calculations. 
Figure A1.2. Actual and fitted values for headline PCE inflation in the United States

Dep. Var.: Q/Q annualised headline PCE inflation (per cent)

Model 1

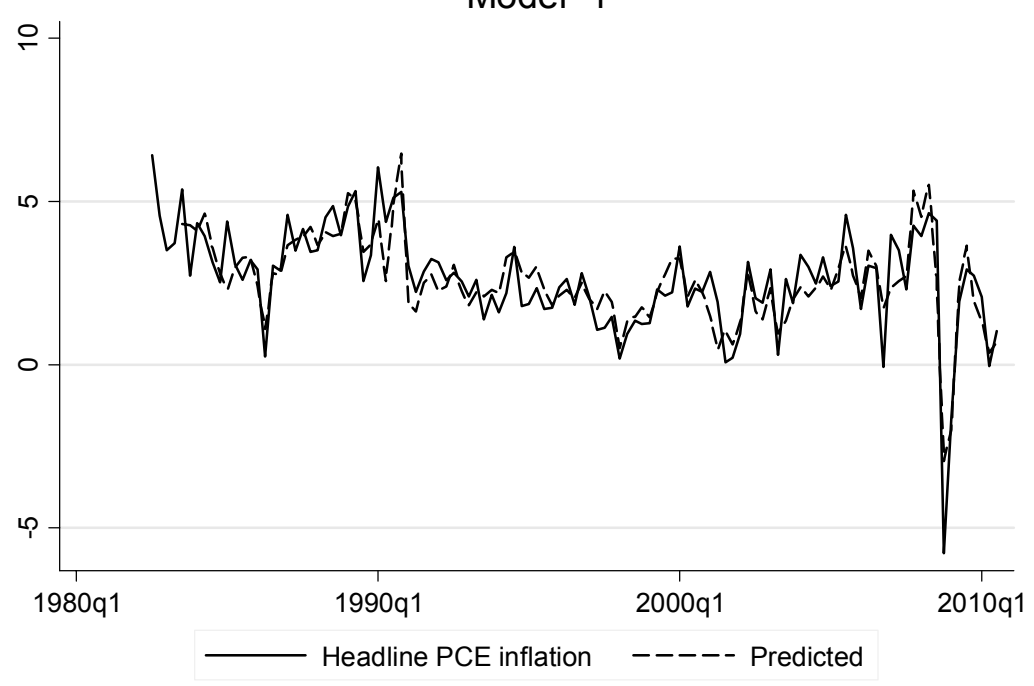

Model 2

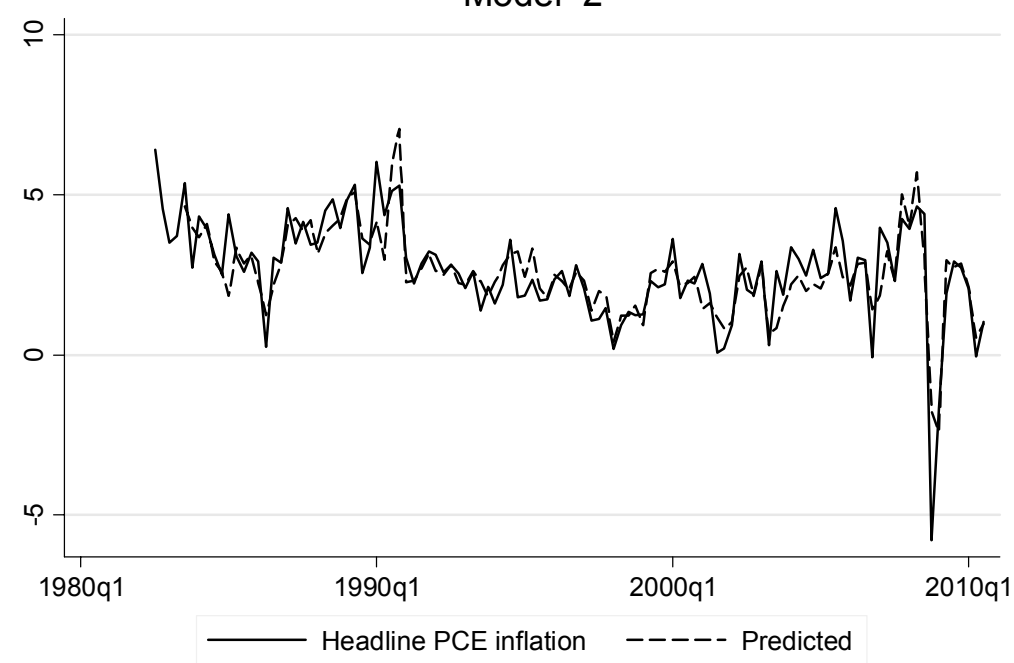

Note: Fitted values are obtained from Models 1 and 2 estimated in Table A1.3.

Source: Authors' calculations. 
Figure A1.3. Actual and fitted values for headline CPI inflation in Japan

Dep. Var.: Y/Y headline CPI inflation (per cent)

Model 1

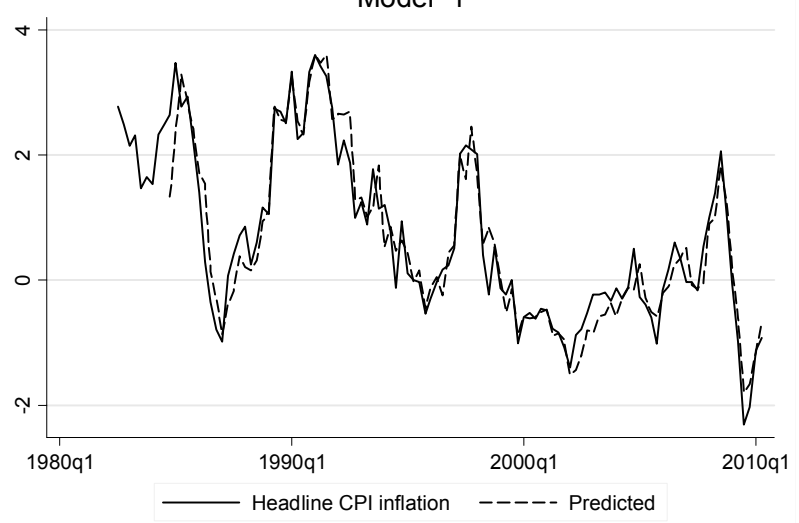

Model 2

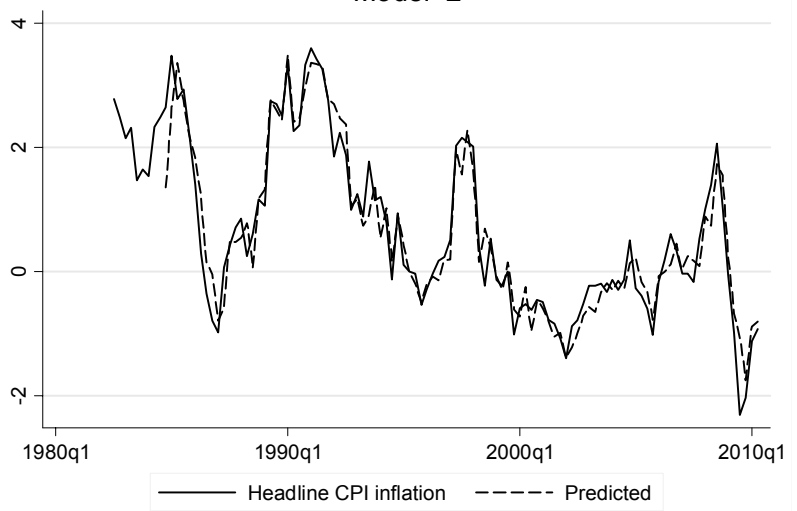

Model 3

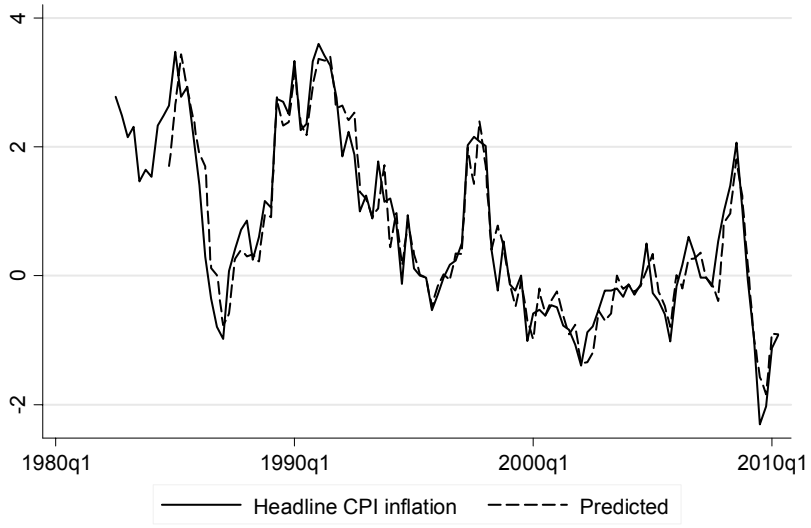

Note: Fitted values are obtained from Models 1, 2 and 3 estimated in Table A1.4.

Source: Authors' calculations. 
Figure A1.4. Actual and fitted values for headline CPI inflation for the United Kingdom Dep. Var.: annualised Q/Q headline CPI inflation (per cent)
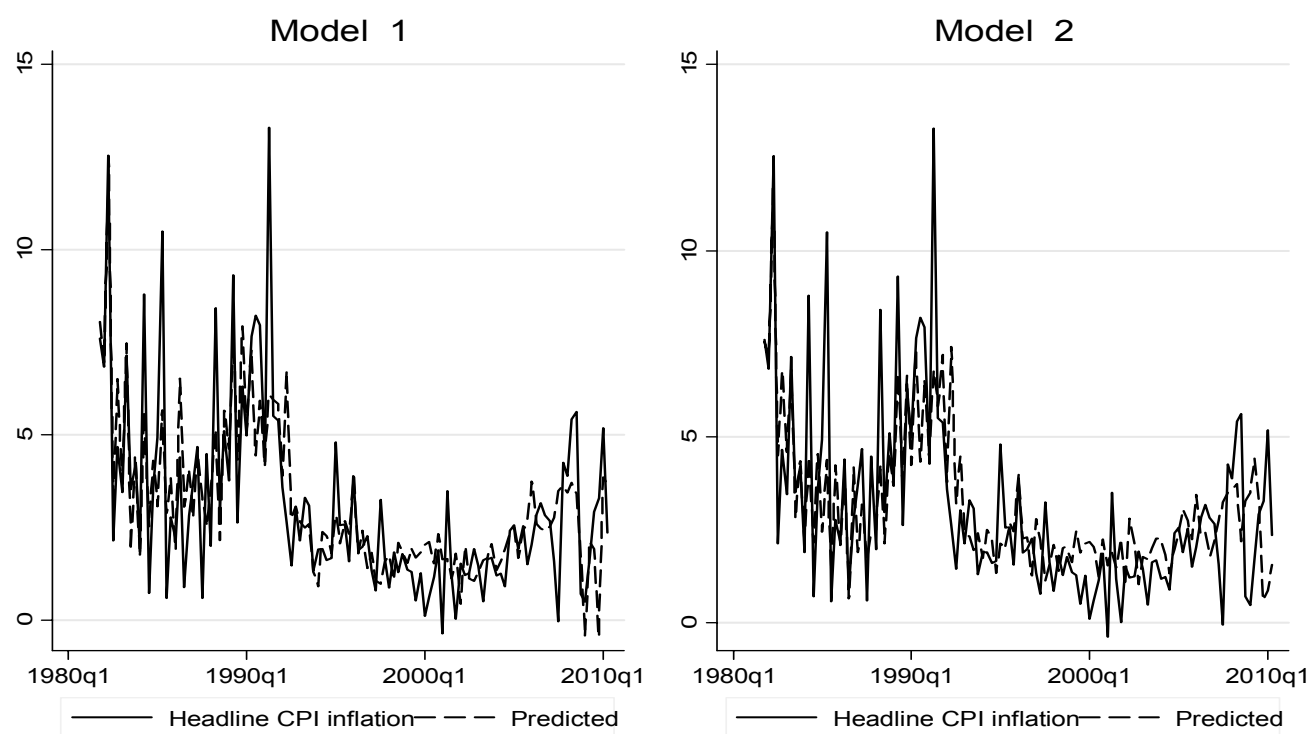

Note: Fitted values are obtained from Models 1 and 2 reported in Table A1.5.

Source: Authors' calculations.

Figure A1.5. Actual and fitted values for headline CPI inflation for the euro area

Dep. Var.: annualised Q/Q headline CPI inflation (per cent)
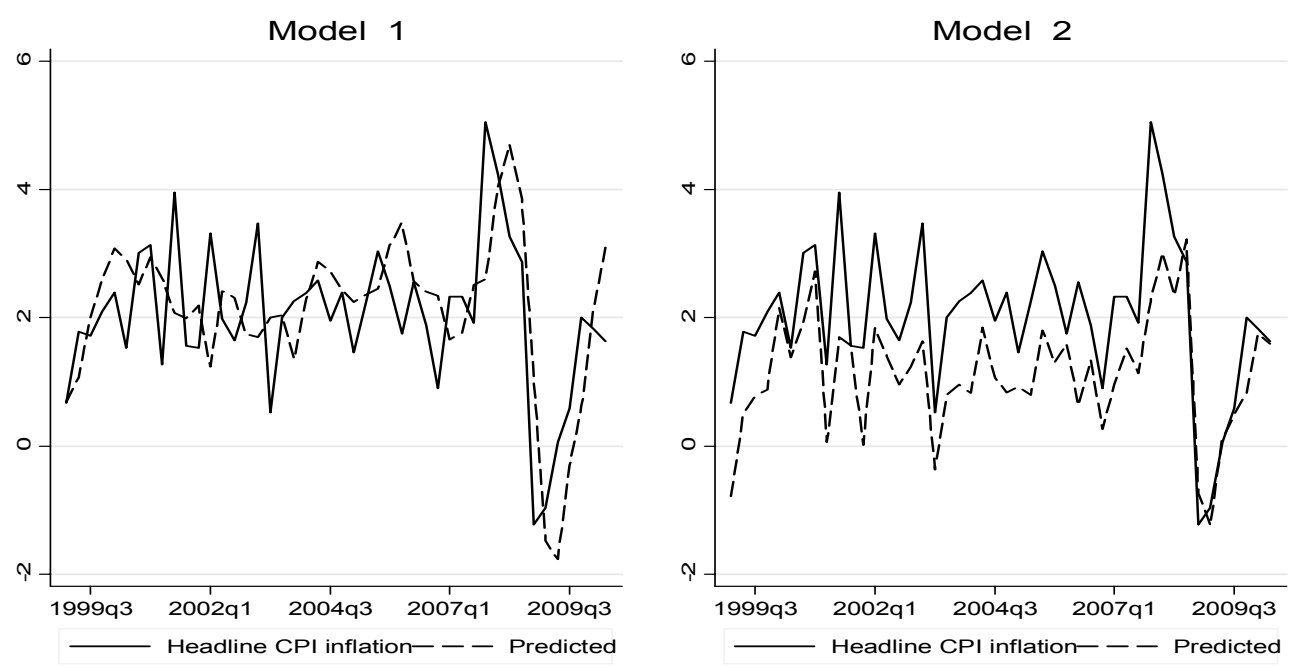

Note: Fitted values are obtained from Models 1 and 2 reported in Table A1.6.

Source: Authors' calculations. 
Figure A1.6. Contribution to headline CPI inflation outcomes in the United States

Percentage point contributions to headline CPI inflation

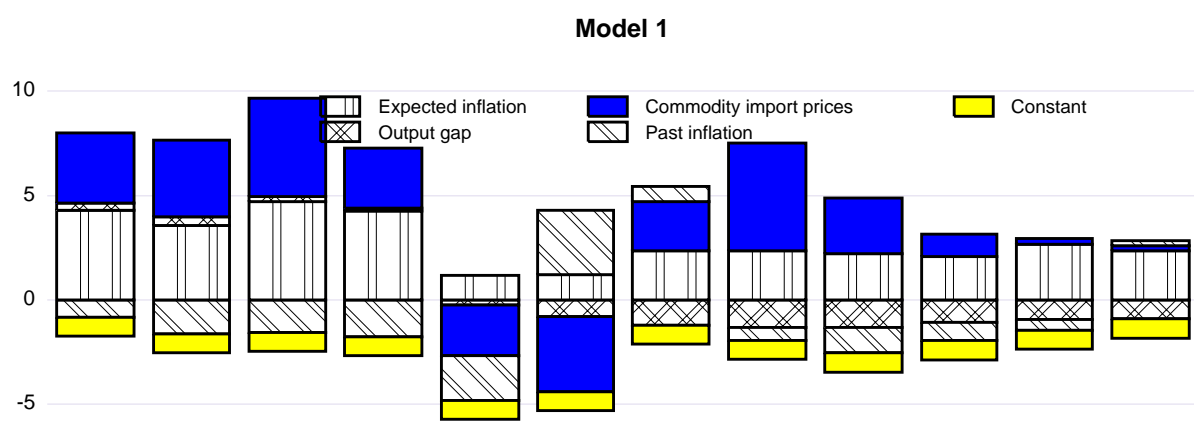

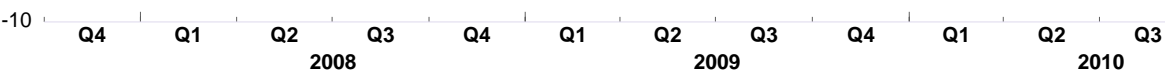

Model 2

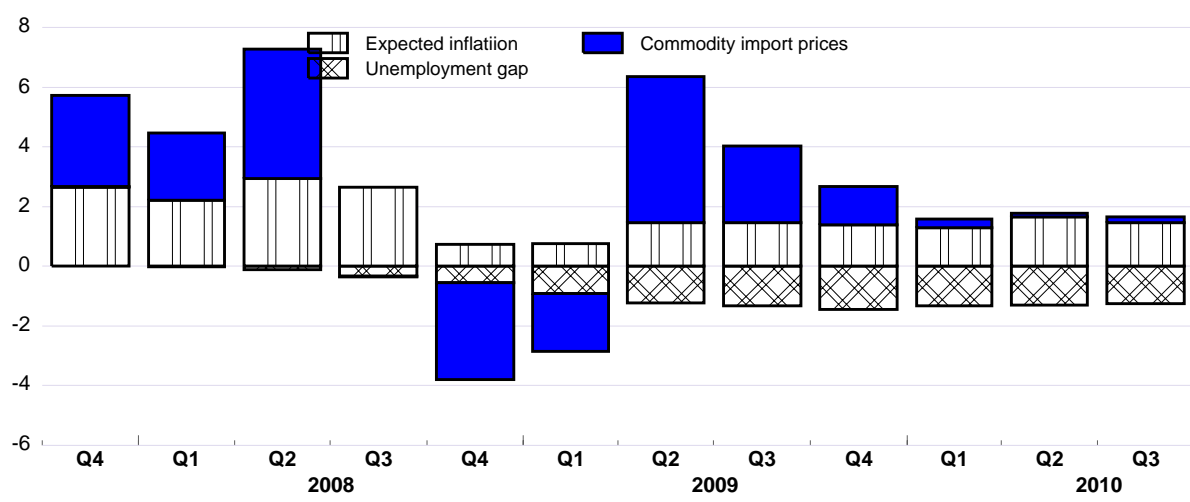

Model 3

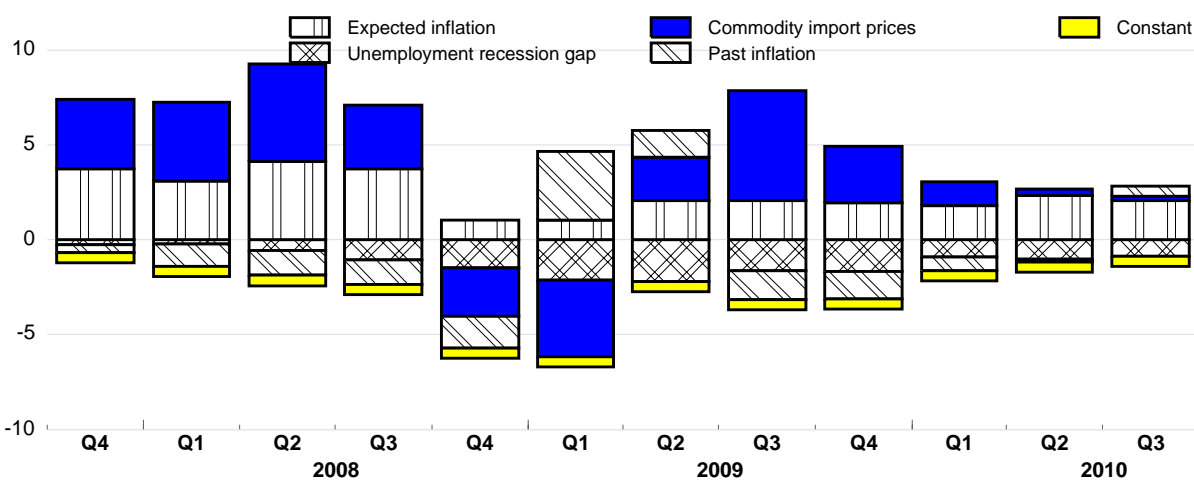

Note: Decomposition based on Models 1, 2 and 3 reported in Table A1.2.

Source: Authors' calculations. 
Figure A1.7. Contribution to headline PCE inflation outcomes in the United States

Percentage point contributions to headline PCE inflation

Model 1
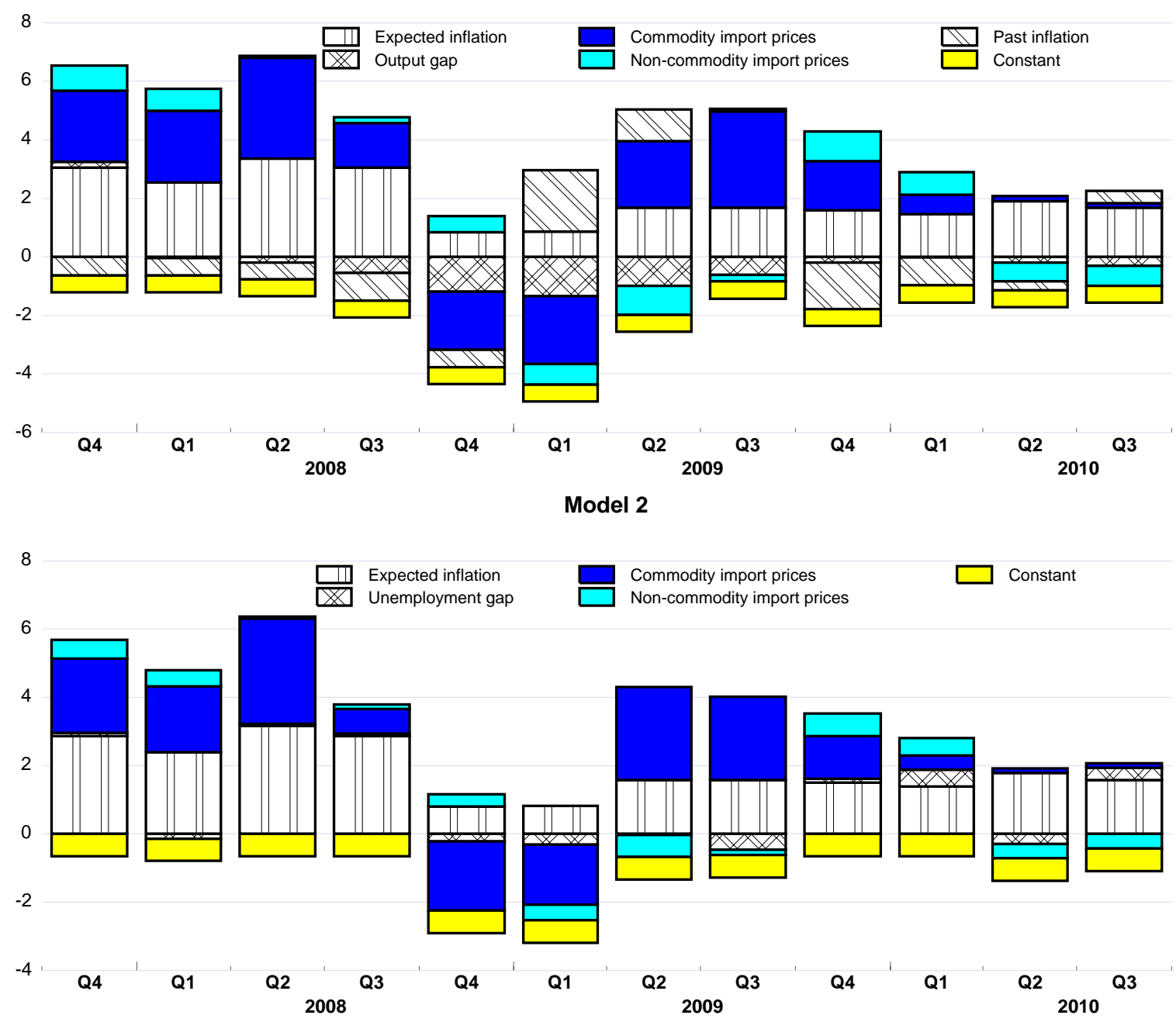

Note: Decomposition based on Models 1 and 2 reported in Table A1.3.

Source: Authors' calculations. 
Figure A1.8. Contribution to headline CPI inflation outcomes in Japan

Percentage point contributions to headline CPI inflation

Model 1

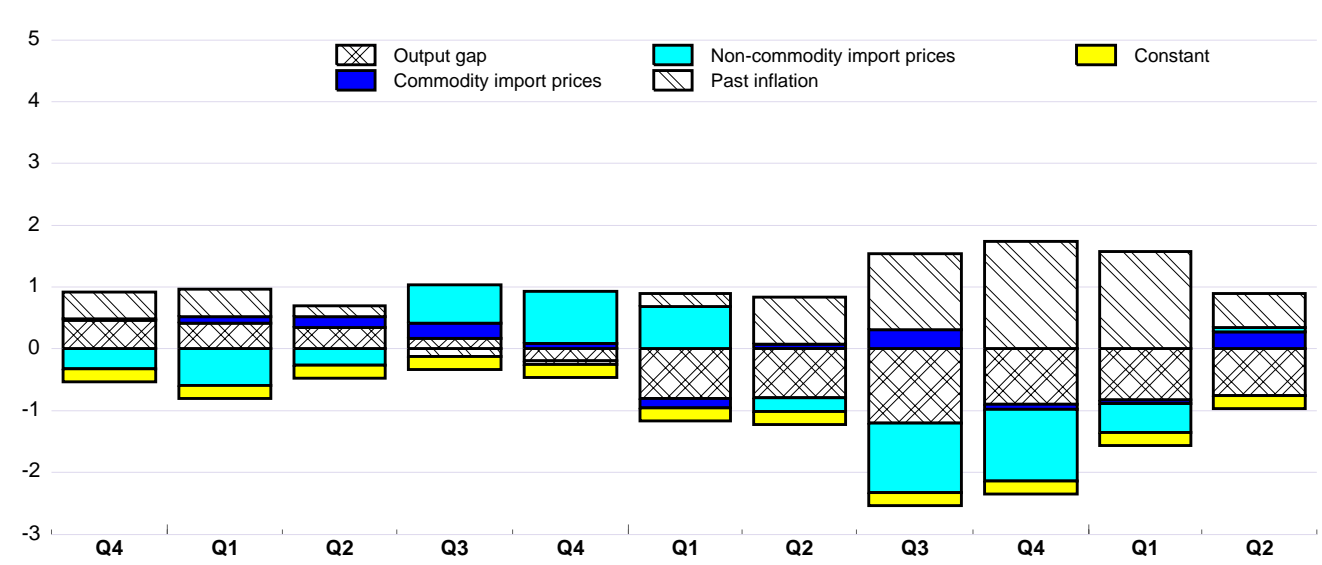

Model 2

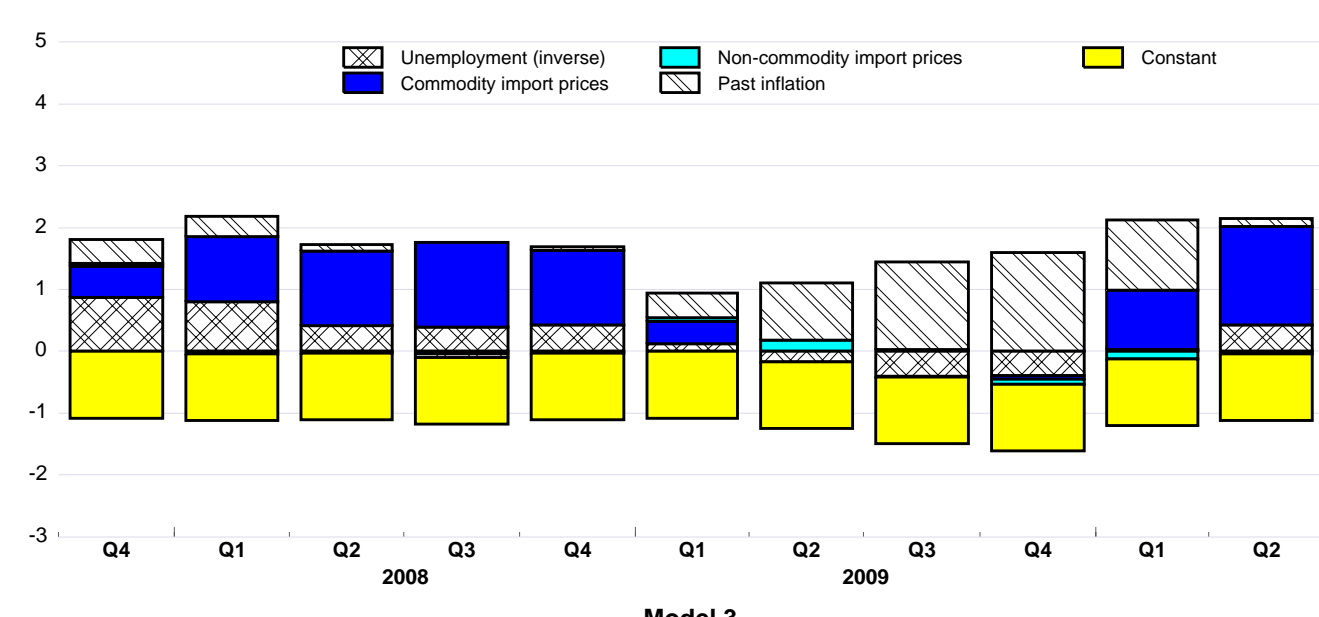

Model 3

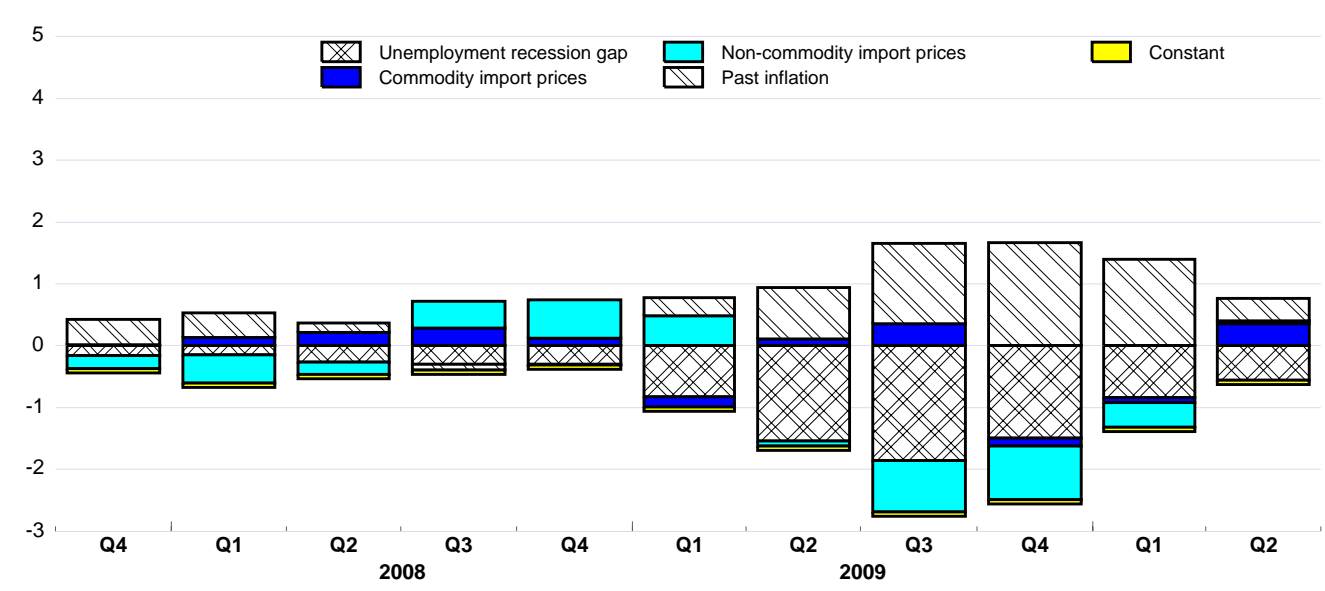

Note: Decomposition based on Models 1, 2 and 3 reported in Table A1.4.

Source: Authors' calculations. 
Figure A1.9. Contribution to headline CPI inflation outcomes in the United Kingdom

Percentage point contributions to headline CPI inflation

\section{Model 1}

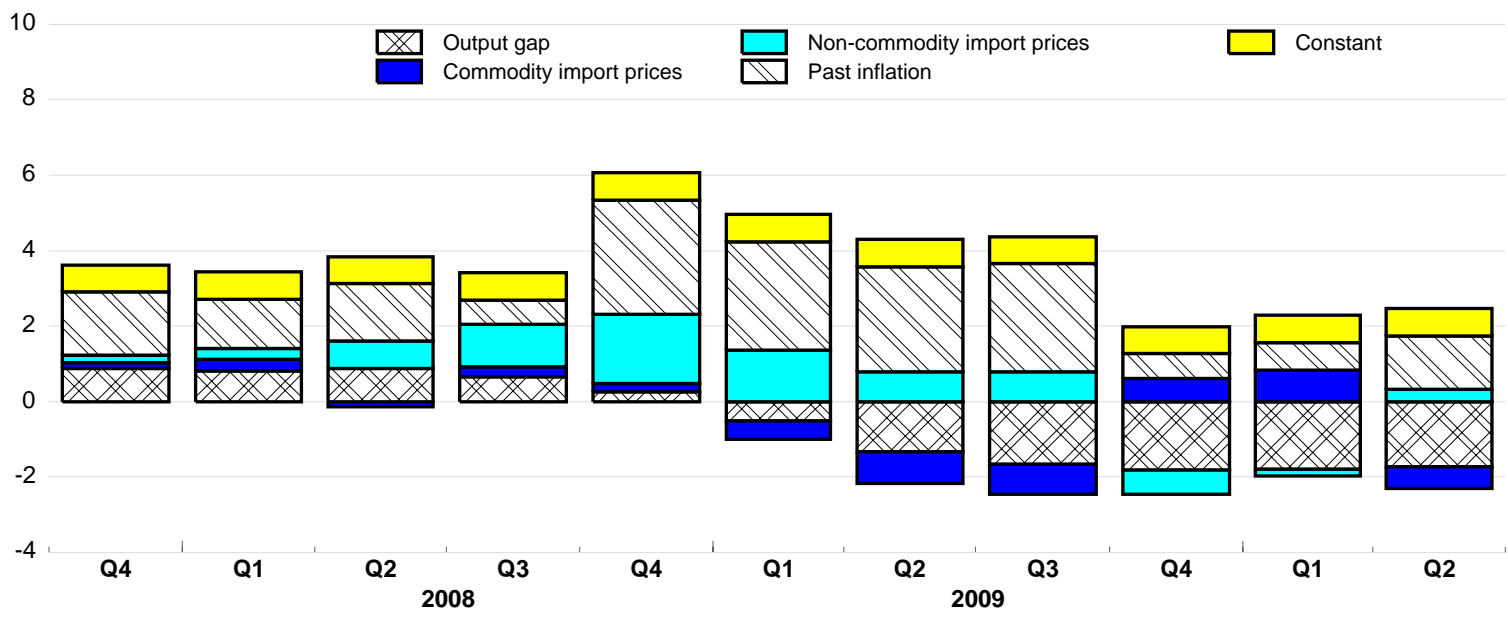

Model 2

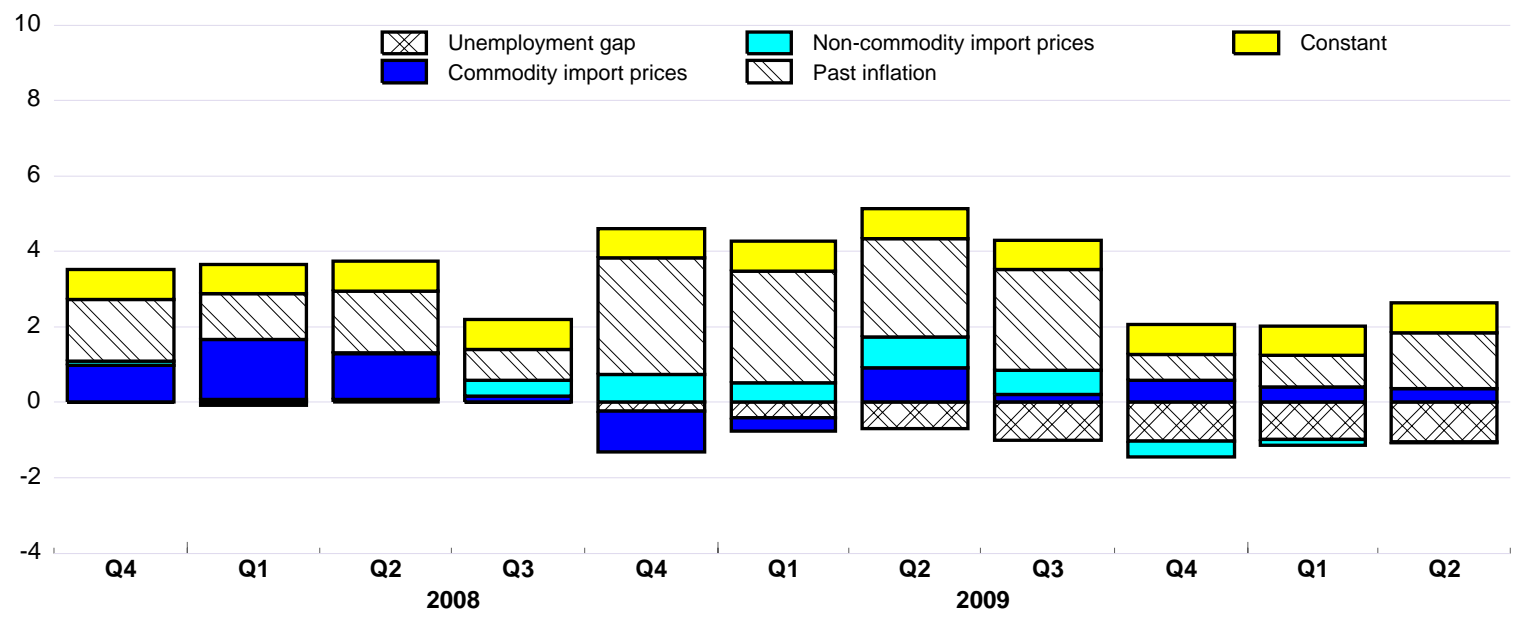

Note: Decomposition based on Models 1, 2 and 3 reported in Table A1.5.

Source: Authors' calculations. 
Figure A1.10. Contribution to headline CPI inflation outcomes in the euro area

Percentage point contributions to headline CPI inflation

Model 1

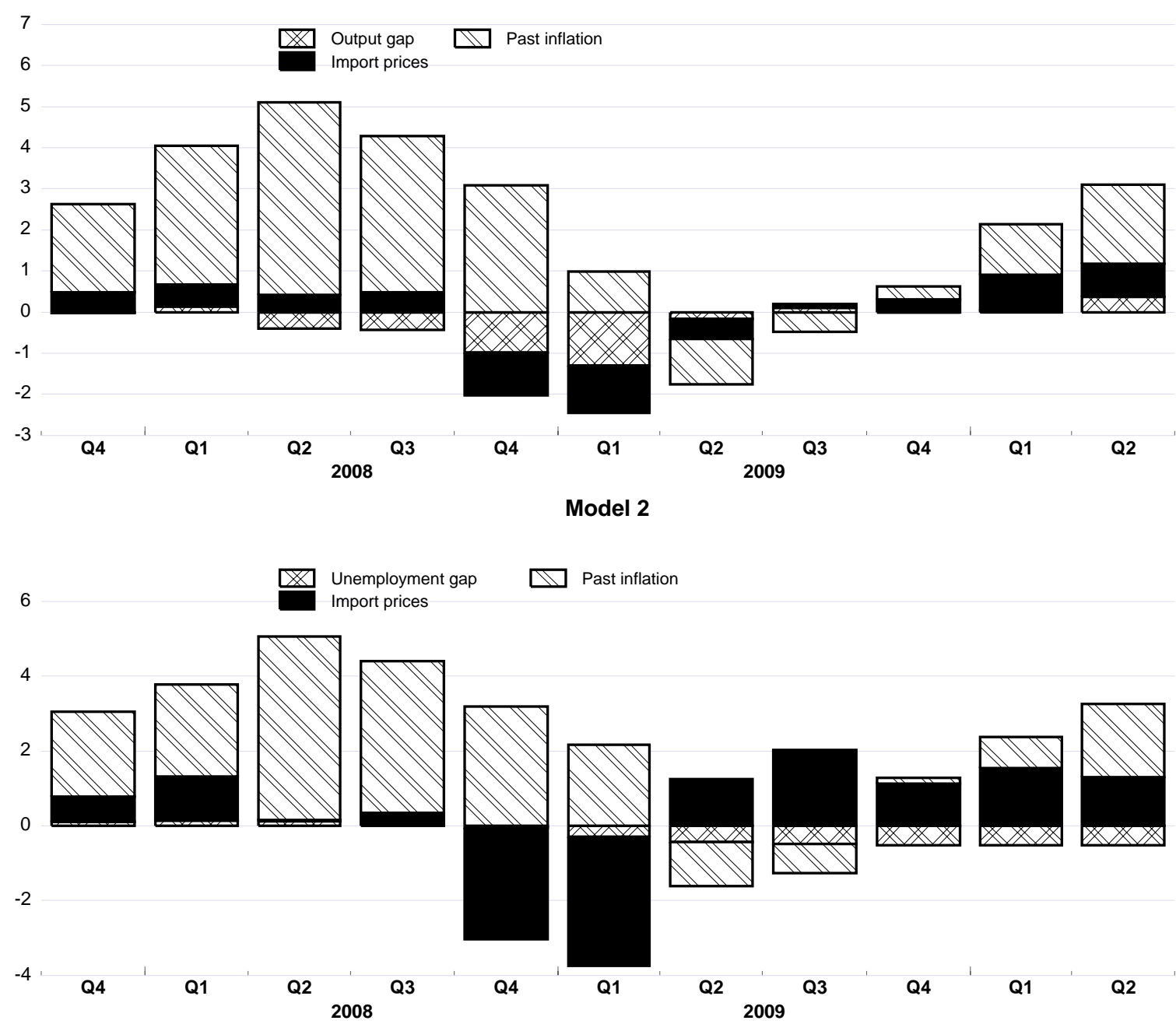

Note: Decomposition based on Models 1 and 2 reported in Table A1.6.

Source: Authors' calculations. 
Figure A1.11. Forecasting headline CPI inflation in the United States

Dep. Var.: Q/Q annualised headline CPI inflation
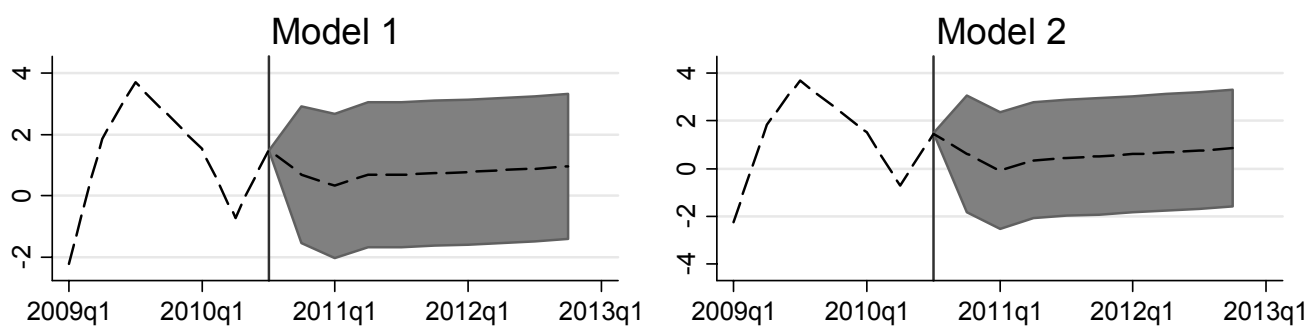

Conf. Interval $\quad---$ Predicted
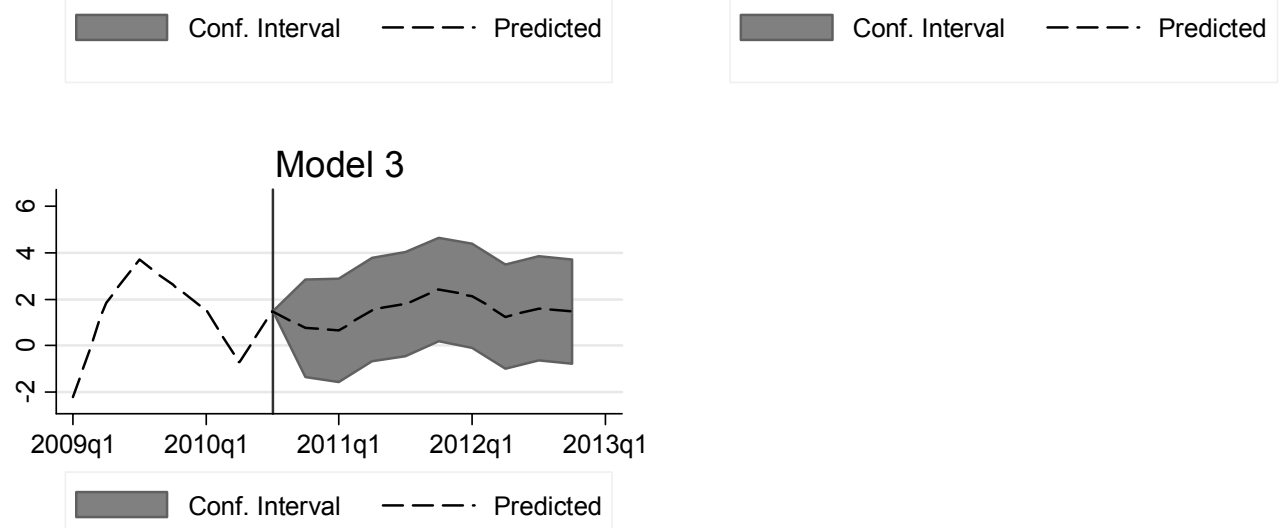

Note: Forecasts are based on Models 1, 2 and 3 reported in Table A1.2 and the projections for the explanatory variables in the Economic Outlook No. 88. 95\% confidence intervals are based on a normal distribution.

Source: Authors' calculations. 
Figure A1.12. Forecasting headline PCE inflation in the United States

Dep. Var.: Q/Q annualised headline PCE inflation (per cent)
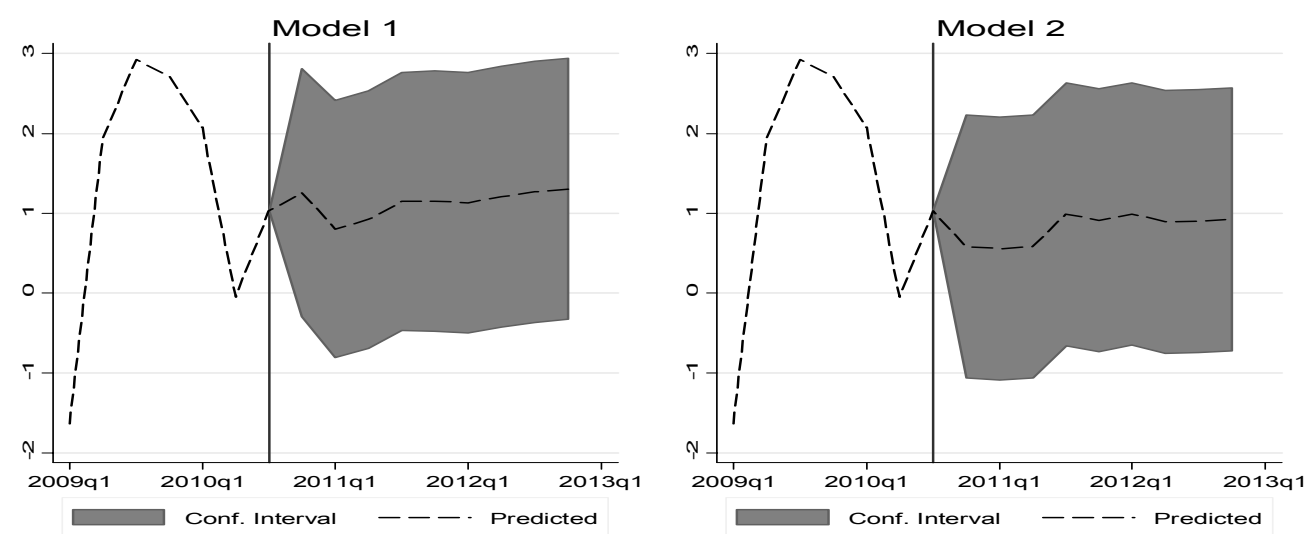

Note: Forecasts are based on Models 1 and 2 reported in Table A1.3 and the projections for the explanatory variables in the Economic Outlook No. 88. 95\% confidence intervals are based on a normal distribution.

Source: Authors' calculations. 


\section{Figure A1.13. Forecasting headline CPI inflation in Japan}

Dep. Var.: Y/Y headline CPI inflation (per cent)
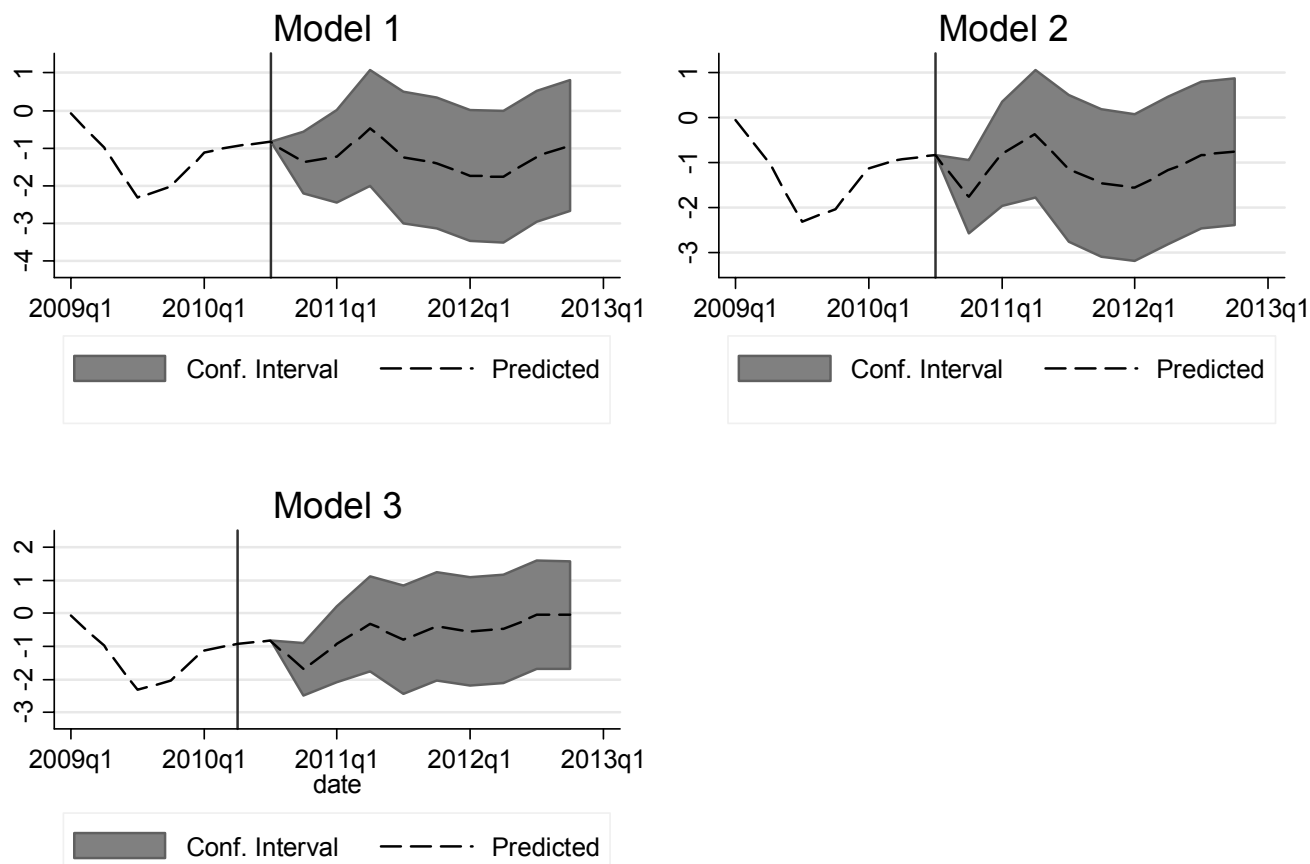

Note: Forecasts are based on Models 1,2 and 3 reported in Table A1.4 and the projections for the explanatory variables in the Economic Outlook No. 88. 95\% confidence intervals are based on a normal distribution.

Source: Authors' calculations. 
Figure A1.14. Forecasting headline CPI inflation in the United Kingdom

Dep. Var.: annualised $Q / Q$ headline $C P I$ inflation (per cent)
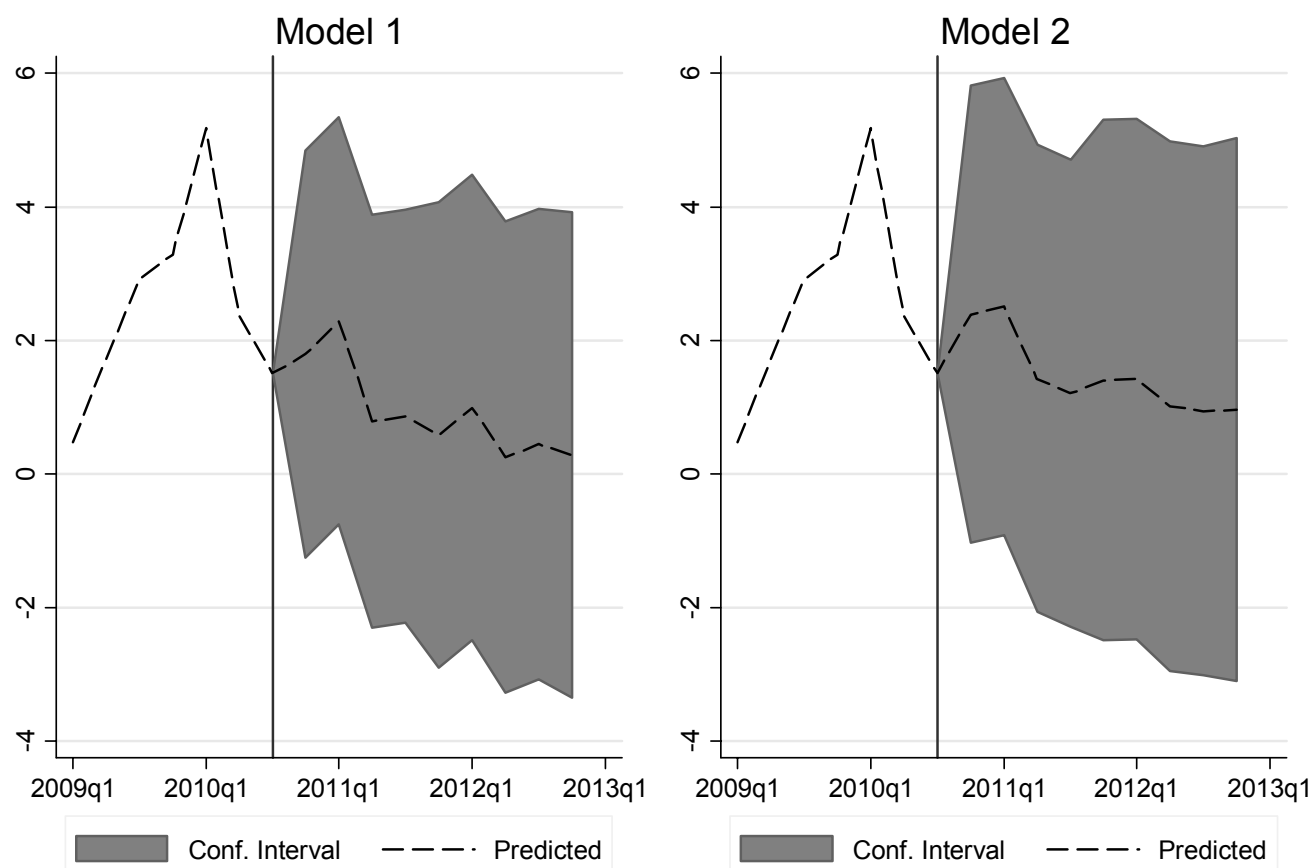

Note: Forecasts are based on Models 1 and 2 reported in Table A1.5 and the projections for the explanatory variables in the Economic Outlook No. 88. 95\% confidence intervals are based on a normal distribution.

Source: Authors' calculations. 
Figure A1.15. Forecasting headline CPI inflation in the euro area

Dep. Var.: annualised Q/Q headline CPI inflation (per cent)
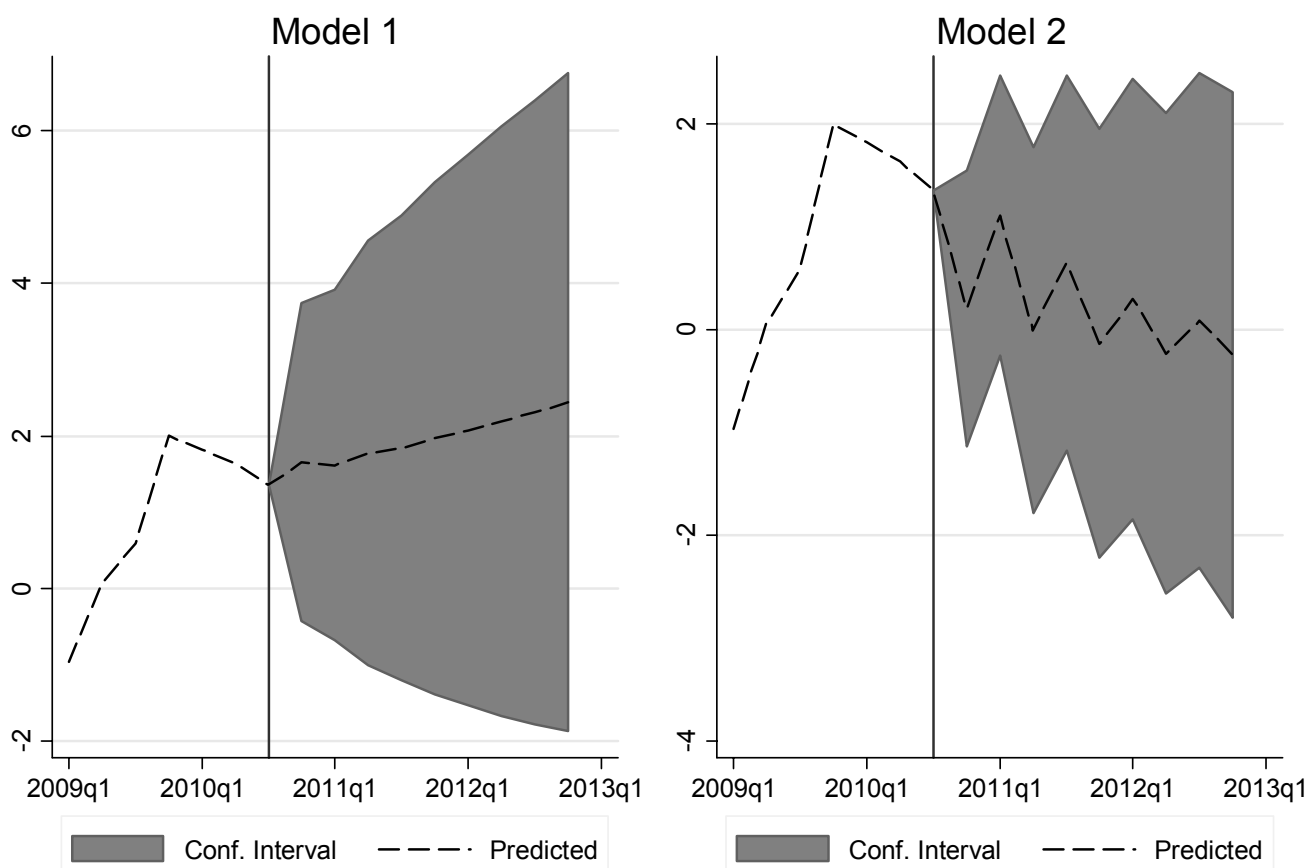

Note: Forecasts are based on Models 1 and 2 reported in Table A. 6 and the projections for the explanatory variables in the Economic Outlook No. 88. 95\% confidence intervals are based on a normal distribution.

Source: Authors' calculations. 


\section{ANNEX 2. DETAILS ON UNIT ROOT TESTS}

76. In cases where inflation seems to exhibit a break, the Lee and Strazicich (2003 and 2004) procedure is used to test for both unit roots and structural breaks in the inflation process. ${ }^{47}$ In the remaining cases the augmented Dickey-Fuller-generalised-least-squares (ADF-GLS) unit root test is used.

77. As the evolution of headline PCE inflation in the United States resembles closely that of the CPI, and given that both variables do not seem to exhibit any obvious trend, a stationary process is assumed based on the results by Halunga et al. (2009) regarding persistence. In contrast, core CPI inflation seems to exhibit a downward trend until the beginning of the 2000s, while core PCE remained elevated during the 1980 s and contracted during the 1990s, to reach a more stable level since the beginning of the 2000s. These variables were tested for the presence of a unit root, allowing for the possibility of one and two breaks in the data generating process, respectively.

78. In the case of Japan and for both price indices, breaks in the data are not easy to detect due to the potential presence of multiple structural breaks. Implementing the Lee and Strazicich (2003 and 2004) test over different sample periods, allowing at each time for up to two structural breaks, gave conflicting results both in terms of the stationary properties of the variables and the location of potential breaks. Hence, the option of implementing an ADF-GLS test including a single trend in the estimating unit-root equation was preferred. $^{48}$

79. For the case of the United Kingdom, the empirical evidence presented in Halunga et al. (2009) shows that headline inflation is stationary starting in 1981, calling to test for the presence of a unit root in core inflation only. In the case of the euro area, both headline and core inflation seem to exhibit one break in trend around 1999, when inflation seems to have been anchored around low and stable levels following the establishment of the single currency. The Lee and Strazicich (2003 and 2004) procedure, allowing for one structural break, is implemented in these cases.

80. Results show that it is not possible to reject the unit root null for Japan (both indices) based on the ADF-GLS test, and for core PCE in the United States and headline CPI in the euro area, when using the Lee and Strazicich procedure (Table 2). For core PCE a break in trend is estimated in the second quarter of 1990 and in the fourth quarter of 2001, while for headline CPI in the euro area the break occurs in the first quarter of 2000. Data are estimated to be stationary around breaks for the core measure of consumer inflation in the United States (second quarter of 2004) and in the euro area (fourth quarter of 1999), and for core inflation in the United Kingdom without breaks.

47. This test has the advantage of allowing for structural breaks in both the null (unit root with breaks) and alternative (stationarity around breaks) hypotheses. The methodology improves upon previous endogenousbreak unit root tests, such as Zivot and Andrews (1992) and Lumsdaine and Papell (1997), which only allow for a break under the alternative hypothesis, leading to spurious rejection.

48. Results for the fit of the models for Japan show nevertheless that there is no apparent structural break left in the residuals. 
81. However, methodological issues can cloud the analysis regarding the presence of unit roots in inflation. For example, annual inflation rates exhibit far more persistence than annualised quarterly variations, which can be a factor underlying the unit root test results for Japan. Moreover, unit root tests may also lack power to distinguish a unit root from a process that exhibits high persistence. This can be the case for headline inflation in the euro area and core PCE inflation in the United States, where moreover data exhibited substantial breaks. Unit root tests implemented on panels rather than time series data, which are more powerful, tend to find that inflation is indeed stationary (Culver and Papell, 1997; Basher and Westerlund, 2008; and Narayan and Narayan, 2010). ${ }^{49}$

Table A2.1. Unit root tests

\begin{tabular}{|c|c|c|c|c|}
\hline Country & Inflation variable & Test & Statistics & Breaks, $t$-stat (date) \\
\hline United States & $\begin{array}{l}\text { Headline CPI and } \\
\text { PCE inflation }\end{array}$ & \multicolumn{3}{|c|}{$\begin{array}{l}\text { Stationary based on empirical results presented in Halunga et al. } \\
\text { (2009). }\end{array}$} \\
\hline & Core CPI & LL & $-4.93^{* *}$ & $3.83^{* * *}(2004 q 2)$ \\
\hline & Core PCE & LL & -4.36 & $\begin{array}{l}2.75^{\star * *}(1990 \mathrm{q} 2), 3.96^{* * *} \\
\quad(2001 \mathrm{q} 4)\end{array}$ \\
\hline Japan & $\begin{array}{r}\text { Headline CPI } \\
\text { Core CPI } \\
\end{array}$ & $\begin{array}{l}\text { ADF-GLS } \\
\text { ADF-GLS }\end{array}$ & $\begin{array}{l}-2.46 \\
-2.29 \\
\end{array}$ & \\
\hline United Kingdom & $\begin{array}{l}\text { Headline CPI } \\
\text { Core CPI }\end{array}$ & \multicolumn{3}{|c|}{$\begin{array}{l}\text { Stationary based on empirical results presented in Halunga et al. } \\
\text { (2009). } \\
\text { ADF-GLS }\end{array}$} \\
\hline Euro area & $\begin{array}{r}\text { Headline CPI } \\
\text { Core CPI }\end{array}$ & $\begin{array}{l}\mathrm{LL} \\
\mathrm{LL}\end{array}$ & $\begin{array}{l}-3.89 \\
-4.17^{*}\end{array}$ & $\begin{aligned}-2.95^{* * *}(2000 q 1) \\
4.06^{* * *}(1999 q 4)\end{aligned}$ \\
\hline
\end{tabular}

Notes: $\mathrm{LL}=$ Lee and Strazicich test. Sample periods are: 1982q3-2010q2 for the United States and Japan; 1981q4-2010q2 for headline CPI and 1996q1-2010q2 for core CPI in the United Kingdom; and 1990q1-2010q2 for the euro area. The number of lags included in the estimations was selected using the Schwartz information criterion for the ADF-GLS test, while it is automatically selected in the Lee and Strazicich test. The maximum number of lags considered is eight for both tests. Inflation is quarter-on-quarter annualised for the United States, the United Kingdom and the euro area, and year-on-year for Japan. Critical values for the MinStatistics were obtained from Lee and Strazicich (2004). $\left({ }^{*}\right),\left({ }^{* *}\right)$ and $\left({ }^{* * *}\right)$ denote statistical significance at the $10 \%, 5 \%$ and $1 \%$ levels, respectively.

Source: Authors' calculations.

49. To be sure, headline inflation was also assumed stationary in the euro area. Results (not reported) show that he inflation process proved very difficult to model with all the explanatory variables resulting insignificant. 


\section{BIBLIOGRAPHY}

Ang, A. G. Bekaertb and M. Wei (2007), "Do macro variables, asset markets, or surveys forecast inflation better?", Journal of Monetary Economics, Vol. 54, pp. 1163-1212.

Ball, L. and N.G. Mankiw (1995), "Relative-price changes as aggregate supply shocks", Quarterly Journal of Economics, Vol. 110, No. 1, pp. 161-93.

Bank of England (2010), Inflation Report, November.

Barnes, M. L. and G. P. Olivei (2003), "Inside and outside bounds: threshold estimates of the Phillips curve", New England Economic Review, 2003 Issue.

Basher, S.A and J. Westerlund (2008), "Is there really a unit root in the inflation rate? More evidence from panel data models", Applied Economics Letters, Vol. 15, pp. 161-64.

Beechey, M.J., B.K. Johannsen and A.T. Levin (2008), "Are long-run inflation expectations anchored more firmly in the euro area than in the United States?", Finance and Economics Discussion Series, 2008-23, Federal Reserve Board.

Beffy, P.O., P. Ollivaud, P. Richardson and F. Sédillot (2006), "New OECD methods for supply-side and medium-term assessment: a capital services approach", OECD Economics Department Working Papers, No. 482.

Bernanke, B.S. (2010), "Monetary policy objectives and tools in a low-inflation environment”, Speech at a conference sponsored by the Federal Reserve Bank of Boston on Revisiting Monetary Policy in a Low-Inflation Environment, October 2010.

Bernanke, B.S., J. Boivin and P. Eliasz (2005), "Measuring the effects of monetary policy: a factoraugmented vector autoregressive (FAVAR) approach", Quarterly Journal of Economics, Vol. 120, pp. 387-422.

Brauer, D. A. (1997), "Do rising labor costs trigger higher inflation?", Current Issues in Economics and Finance, Vol. 3, No. 11, Federal Reserve Bank of New York.

Cabinet Office (2003), Annual Report on the Japanese Economy and Public Finance, Government of Japan, October.

Catte, P. and T. Sløk (2005), "Assessing the value of indicators of underlying inflation for monetary policy”, OECD Economics Department Working Papers, No. 461.

Cournède, B. (2005), "House prices and inflation in the Euro Area", OECD Economics Department Working Paper, No. 450. 
Cournède, B., A. Janovskaia and P. van den Noord (2005), "Sources of inflation persistence in the Euro Area", OECD Economics Department Working Paper, No. 435.

Cournède, B. and D. Moccero (2009), "Is there a case for price-level targeting?", OECD Economics Department Working Paper, No. 721.

Cournède, B. and M. Minegishi (2009), "The role of transparency in the conduct of monetary policy", OECD Economics Department Working Paper, No. 724.

Culver, S.A. and D. H. Papell (1997), "Is there a unit root in the inflation rate? Evidence from sequential break and panel data models", Journal of Applied Econometrics, Vol. 12, pp. 435-444.

De Veirman, E. (2007), "Which nonlinearity in the Phillips curve? The absence of accelerating deflation in Japan”, Discussion Paper Series, No. 14, Reserve Bank of New Zealand.

Debelle, G. and J. Wilkinson (2002), "Inflation targeting and the inflation process: some lessons from an open economy", Research Discussion Paper, No. 01, Reserve Bank of Australia.

Dwyer, A., K. Lam and A. Gurney (2010),'Inflation and the output gap in the UK", HM Treasury Economic Working Paper, No. 6.

ECB (2010), "Drivers of Recent Inflation Developments", Monthly Bulletin, European Central Bank, November.

Eliasson, A.C. (2001), "Is the short-run Phillips curve nonlinear? Empirical evidence for Australia, Sweden and the United States", Sveriges Riksbank Working Paper, No. 124, , Stockholm.

Fuhrer, J., G. Olivei and G.M.B. Tootell (2009), "Empirical Estimates of Changing Inflation Dynamics", Working Paper, No. 09-4, Federal Reserve Bank of Boston, May.

Fuhrer, J.C. (1997), "The (un)importance of forward-looking behavior in price specifications", Journal of Money, Credit, and Banking, Vol. 29, No. 3, pp. 338-350.

Fuhrer, J.C. and G.P. Olivei (2010), "The role of expectations and output in the inflation process: an empirical assessment", Public Policy Brief, No. 10-2, Federal Reserve Bank of Boston.

Fuhrer, J.C. and G.R. Moore (1995), "Inflation persistence", Quarterly Journal of Economics, Vol. 440, pp. 127-159.

Galati, G., S. Poelhekke, and C. Zhou (2010), "Did the crisis affect inflation expectations?", Presented at the conference Monetary Policy Lessons from the Global Crisis, International Journal of Central Banking and Bank of Japan.

Gali, J. and M. Gertler (1999), "Inflation dynamics: a structural econometrics analysis", Journal of Monetary Economics, Vol. 44, No. 2, pp. 195-222.

Galí, J., M. Gertler, and D. Lopez-Salido (2005), "Robustness of the estimates of the hybrid New Keynesian Phillips curve", Journal of Monetary Economics, Vol. 52, No. 6, pp. 1107-18.

Gordon, R.J., (1997), "The time-varying NAIRU and its implications for economic policy", Journal of Economic Perspectives, Vol. 11, No. 1, pp. 11-32. 
Guichard, S. and E. Rusticelli (2010), "Assessing the impact of the financial crisis on structural unemployment in OECD countries", OECD Economics Department Working Paper, No. 767.

Guidolin, M. and C. J. Neely (2010), "The effects of large-scale asset purchases on TIPS inflation expectations", National Economic Trends, September Issue, Federal Reserve Bank of St. Louis.

Haldane, A. and D. Quah (1999), "UK Phillips curves and monetary policy”, Discussion Paper, No. 2292, Centre for Economic Policy Research, London.

Halunga, D., R. Osborn and M. Sensier (2009), "Changes in the order of integration of US and UK inflation", Economics Letters, Vol. 102, pp. 30-32.

Hooper, P. (2010), Comment on "Inflation Dynamics when inflation is near zero" (by Fuhrer, Olivei and Tootell, 2010), Deutsche Bank Global Economic Perspectives, October.

Hu, L. and M. Toussaint-Comeau (2010), "Do labor market activities help predict inflation?", Economic Perspectives, $2^{\text {nd }}$ Quarter, Federal Reserve Bank of Chicago.

Kara, K. and E. Nelson (2002), "The exchange rate and inflation in the UK", External MPC Unit Discussion Paper No. 11, Bank of England.

Kleibergen, F. and S. Mavroeidis (2009), "Weak instrument robust tests in GMM and the New Keynesian Phillips curve", Journal of Business and Economic Statistics, Vol. 27, pp. 293-311.

Koske, I. and N. Pain (2008), "The usefulness of output gaps for policy analysis", OECD Economics Department Working Paper, No. 321.

Lee, J. and M.C. Strazicich (2003). "Minimum Lagrange multiplier unit root test with two structural breaks", Review of Economics and Statistics, MIT Press, Vol. 85, No. 4, pp. 1082-89.

Lee, J. and M.C. Strazicich (2004), "Minimum Lagrange multiplier unit root test with one structural break", Working Paper, No. 04-17, Department of Economics, Appalachian State University.

Levin, A. T. and J. B. Taylor (2010), "Falling behind the curve: a positive analysis of stop-start monetary policies and the great inflation", Working Paper, No. 15630, National Bureau of Economic Research, Cambridge, MA.

Llaudes, R. (2005), "The Phillips curve and long-term unemployment", Working Paper, No. 441, European Central Bank.

Lumsdaine, R. and D. Papell (1997), "Multiple trend breaks and the unit-root hypothesis", Review of Economics and Statistics, Vol. 79, No. 2, pp. 212-18.

Meier, A. (2010), "Still minding the gap - Inflation dynamics during episodes of persistent large output gaps", IMF Working Paper, No. 189, Washington, D.C.

Mestre, R. (2007), “Are survey-based Inflation expectations In the euro area Informative?", Working Paper, No. 721, European Central Bank.

Mio, H. (2001), “The Phillips Curve and Underlying Inflation”, Monetary and Economic Studies, Vol. 19, No. 2, pp. 85-107. 
Mourougane, A. and H. Ibaragi (2004), "Is there a change in the trade-off between output and inflation at low or stable inflation rates? Some evidence in the case of Japan", OECD Economics Department Working Paper, No. 379.

Musso, A., L. Stracca and D. von Dijk (2007), "Instability and nonlinearity in the euro area Phillips curve", Working Paper, No. 811, European Central Bank.

Narayana, P.K. and S. Narayan (2010), "Is there a unit root in the inflation rate? New evidence from panel data models with multiple structural breaks", Applied Economics, Vol. 42, pp. 1661-70.

Nishizaki, K. and T. Watanabe (2000), "Output-inflation trade-off at near-zero inflation rates", Journal of the Japanese and International Economies, No. 14, pp. 304-26.

OECD (2009), "Beyond the Crisis: Medium-Term Challenges Relating to Potential Output, Unemployment and Fiscal Positions", OECD Economic Outlook No. 85, Paris.

Pain, N., I. Koske and M. Sollie (2006), "Globalisation and inflation in the OECD economies", OECD Economics Department Working Paper, No. 524.

Paloviita. M. and M. Virén (2005), "The role of expectations in the inflation process in the euro area", Bank of Finland Research Discussion Papers, No. 6.

Richardson, P., L. Boone, C. Giorno, M. Meacci, D. Rae and D. Turner: "The concept, policy use and measurement of structural unemployment: estimating a time varying NAIRU across 21 OECD countries", OECD Economics Department Working Paper, No. 250.

Romer, D. (2006), Advanced Macroeconomics, New York: McGraw-Hill.

Rudd, J., and K. Whelan (2005), "New tests of the New Keynesian Phillips curve", Journal of Monetary Economics, Vol. 52, No. 6, pp. 1167-81.

Sbordone, A. M. (2002), "Prices and unit labor costs: a new test of price stickiness", Journal of Monetary Economics, Vol. 49, pp. 265-292.

Shirota, T. (2007), "Phillips correlation and trend inflation under the kinked demand curve", Bank of Japan Working Paper Series, No.07-E-5.

Stock, J. and M.W. Watson (1999), "Why has U.S. inflation become harder to forecast?", Journal of Money, Credit and Banking, Vol. 39, No. 1, pp. 3-33.

Stock, J.H. and M. Watson (2002), "Forecasting using principal components from a large number of predictors", Journal of the American Statistical Association, Vol. 97, pp. 1167-79.

Stock, J.H. and M.W. Watson (2008), "Phillips curve inflation forecasts", Working Paper, No. 14322, National Bureau of Economic Research, Cambridge, MA.

Stock, J.H. and M.W. Watson (2010), "Modeling inflation after the crisis", Working Paper, No. 16488, National Bureau of Economic Research, Cambridge, MA.

Thomas, L. B. (1999), "Survey Measures of Expected U.S. Inflation”, Journal of Economic Perspectives, Vol. 13, No. 4, pp. 125-44. 
Trehan, B. (2010), "Survey measures of expected inflation and the inflation process", Working Paper Series, No. 2009-10, Federal Reserve Bank of San Francisco.

Turner, D. (1995), "Speed limit and asymmetric inflation effects from the output gap in the major seven economies", OECD Economic Studies, No. 24, pp.57-88.

Vogel, L., E. Rusticelli, P. Richardson, S. Guichard and C. Gianella (2009), "Inflation responses to recent shocks: do G7 countries behave differently?", OECD Economics Department Working Paper, No. 689.

Yamamoto, I. (2008), "Changes in wage adjustment, employment adjustment and Phillips curve: Japan's experience in the 1990s", Keio/Kyoto Joint Global COE Discussion Paper Series, No. 024.

Zhang, C., D.R. Osborn, and D.H. Kim (2009), "Observed inflation forecasts and the New Keynesian Phillips curve", Oxford Bulletin of Economics and Statistics, Vol. 71, No. 3, pp. 375-98.

Zivot, E. and D.W.K. Andrews (1992), "Further evidence on the Great Crash, the oil-price shock and the unit root hypothesis", Journal of Business and Economic Statistics, Vol. 10, pp. 251-70. 
ECO/WKP(2011)23

\section{WORKING PAPERS}

The full series of Economics Department Working Papers can be consulted at www.oecd.org/eco/workingpapers/

853 Mitigation potential of removing fossil fuel subsidies: A general equilibrium assessment (April 2011) by J.M. Burniaux and J. Chateau

852 Enhancing labour utilisation in a socially inclusive society in Australia (April 2011) by Vassiliki Koutsogeorgopoulou

851 Meeting infrastructure needs in Australia (March 2011) by Claude Giorno

850 Restoring fiscal sustainability in Spain

(March 2011) by Pierre Beynet, Andrés Fuentes, Robert Gillingham and Robert Hagemann

849. Drivers of homeownership rates in selected OECD countries

(March 2011) by Dan Andrews and Aida Caldera Sánchez

848. How efficient are banks in Hungary?

(February 2011) by Margit Molnár and Dániel Holló

847. Strengthening the macroeconomic policy framework in South Africa (February 2011) by Tatiana Lysenko and Geoff Barnard

846. To move or not to move: what drives residential mobility rates in the OECD? (February 2011) by Aida Caldera Sánchez and Dan Andrews

845. Reforming the labour market in Spain (February 2011) by Anita Wölfl and Juan S. Mora-Sanguinetti

844. Macroeconomic Impact of Basel III (February 2011) by Patrick Slovik and Boris Cournède

843. The policy and institutional drivers of economic growth across OECD and non-OECD economies: new evidence from growth regressions by Romain Bouis, Romain Duval, and Fabrice Murtin

842. Limiting Long-Term Unemployment and Non-Participation in Sweden (February 2011) by Niels-Jakob Harbo Hansen

841. Enhancing the cost-effectiveness of climate change mitigation policies in Sweden (February 2011) by Stéphanie Jamet

840. Policies towards a sustainable use of water in Spain (February 2011) by Andrés Fuentes 
ECO/WKP(2011)23

839. Increasing public sector efficiency in Slovakia (January 2011) by Felix Hüfner

838. Raising education outcomes in Switzerland (January 2011) by Andrés Fuentes

837. The Price Responsiveness of Housing Supply in OECD Countries (January 2011) by Aida Caldera Sánchez and Åsa Johansson

836. Housing markets and structural policies in OECD countries (January 2011) by Dan Andrews, Aida Caldera Sánchez and Åsa Johansson

835. Raising potential growth after the crisis: A quantitative assessment of the potential gains from various structural reforms in the OECD area and beyond (January 2011) by Romain Bouis and Romain Duval

834. The GDP impact of reform: a simple simulation framework (January 2011) by Sebastian Barnes, Romain Bouis, Philippe Briard, Sean Dougherty and Mehmet Eris

833. Improving the flexibility of the Dutch housing market to enhance labour mobility (January 2011) by Jens Høj

832. Making the Dutch pension system less vulnerable to financial crises (January 2011) by Jens Høj

831. Real house prices in OECD countries: the role of demand shocks and structural policy factors (December 2010) by Dan Andrews

830. International financial integration and the external positions of euro area countries (December 2010) by Philip R. Lane

829. Improving fiscal performance through fiscal councils (December 2010) by Robert Hagemann

828. Minimising risks from imbalances in European banking (December 2010) by Sebastian Barnes, Philip Lane and Artur Radziwill

827. Resolving and avoiding unsustainable imbalances (December 2010) by Sebastian Barnes

826. Current account imbalances in the euro area: a comparative perspective (December 2010) by Sebastian Barnes, Jeremy Lawson and Artur Radziwill 